Louisiana State University

LSU Digital Commons

$2-1-2006$

\title{
MPI-DING reference glasses for in situ microanalysis: New reference values for element concentrations and isotope ratios
}

\author{
Klaus Peter Jochum \\ Max Planck Institute for Chemistry \\ Brigitte Stoll \\ Max Planck Institute for Chemistry \\ Kirstin Herwig \\ Max Planck Institute for Chemistry \\ Matthias Willbold \\ Max Planck Institute for Chemistry \\ Albrecht W. Hofmiann \\ Max Planck Institute for Chemistry
}

See next page for additional authors

Follow this and additional works at: https://digitalcommons.lsu.edu/geo_pubs

\section{Recommended Citation}

Jochum, K., Stoll, B., Herwig, K., Willbold, M., Hofmiann, A., Amini, M., Aarburg, S., Abouchami, W., Hellebrand, E., Mocek, B., Raczek, I., Stracke, A., Alard, O., Bouman, C., Becker, S., Dücking, M., Brätz, H., Klemd, R., De Bruin, D., Canil, D., Cornell, D., De Hoog, C., Dalpé, C., Danyushevshy, L., Eisenhauer, A., Gao, Y., Snow, J., Groschopf, N., Günther, D., Latkoczy, C., Guillong, M., Hauri, E., \& Höfer, H. (2006). MPI-DING reference glasses for in situ microanalysis: New reference values for element concentrations and isotope ratios. Geochemistry, Geophysics, Geosystems, 7 (2) https://doi.org/10.1029/2005GC001060

This Article is brought to you for free and open access by the Department of Geology and Geophysics at LSU Digital Commons. It has been accepted for inclusion in Faculty Publications by an authorized administrator of LSU Digital Commons. For more information, please contact ir@lsu.edu. 


\section{Authors}

Klaus Peter Jochum, Brigitte Stoll, Kirstin Herwig, Matthias Willbold, Albrecht W. Hofmiann, Marghaleray Amini, Susanne Aarburg, Wafa Abouchami, Eric Hellebrand, Beate Mocek, Ingrid Raczek, Andreas Stracke, Olivier Alard, Claudia Bouman, Stefan Becker, Marc Dücking, Helene Brätz, Reiner Klemd, Deon De Bruin, Dante Canil, Dave Cornell, Cees Jan De Hoog, Claude Dalpé, Leonid Danyushevshy, Anton Eisenhauer, Yongjun Gao, Jonathan E. Snow, Nora Groschopf, Detlef Günther, Christopher Latkoczy, Marcel Guillong, Erik H. Hauri, and Heidi E. Höfer 


\title{
MPI-DING reference glasses for in situ microanalysis: New reference values for element concentrations and isotope ratios
}

\author{
Klaus Peter Jochum, Brigitte Stoll, Kirstin Herwig, Matthias Willbold, \\ and Albrecht W. Hofmann \\ Max-Planck-Institut für Chemie, Postfach 3060,D-55020 Mainz, Germany (kpj@mpch-mainz.mpg.de) \\ Marghaleray Amini \\ Max-Planck-Institut für Chemie, Postfach 3060, D-55020 Mainz, Germany \\ Leibniz-Institut für Meereswissenschaften, IFM-GEOMAR, Wischofstr. 1-3, D-24148 Kiel, Germany
}

Susanne Aarburg

Monash University, P.O. Box 28E, Clayton, Victoria 3800, Australia

Wafa Abouchami, Eric Hellebrand, Beate Mocek, Ingrid Raczek, and Andreas Stracke Max-Planck-Institut für Chemie, Postfach 3060, D-55020 Mainz, Germany

\section{Olivier Alard}

The Open University, Milton Keynes MK7 6AA, UK

Now at Université Montpellier 2, Place Eugène Bataillon, F-34095 Montpellier Cedex 05, France

\section{Claudia Bouman}

Thermo Electron GmbH, Finnigan Advanced Mass Spectrometry, Hanna-Kunath-Str. 11, D-28199 Bremen, Germany

\section{Stefan Becker and Marc Dücking}

Bundeskriminalamt, D-65173 Wiesbaden, Germany

\section{Helene Brätz and Reiner Klemd}

Universität Würzburg, Am Hubland, D-97074 Würzburg, Germany

\section{Deon de Bruin}

Council for Geoscience, Private Bag X112, Pretoria, 0001, South Africa

\section{Dante Canil}

University of Victoria, Victoria, British Columbia, Canada V8W $3 P 6$

Dave Cornell and Cees-Jan de Hoog

Gothenburg University, Box 460, SE-40530 Göteborg, Sweden

Claude Dalpé

Royal Canadian Mounted Police - Forensic Laboratory Services, 1200 Vanier Parkway, Ottawa, Ontario, Canada K1A OR2

\section{Leonid Danyushevsky}

University of Tasmania, Private Bag 79, Hobart, Tasmania 7001, Australia

\section{Anton Eisenhauer}

Leibniz-Institut für Meereswissenschaften, IFM-GEOMAR, Wischofstr. 1-3, D-24148 Kiel, Germany 


\section{Yongjun Gao and Jonathan E. Snow}

Max-Planck-Institut für Chemie, Postfach 3060, D-55020 Mainz, Germany

Now at Department of Geosciences, University of Houston, Houston, Texas 77204, USA

\section{Nora Groschopf}

Universität Mainz, D-55099 Mainz, Germany

\section{Detlef Günther and Christopher Latkoczy}

ETH Hönggerberg, HCI, G113, CH-8093 Zürich, Switzerland

\section{Marcel Guillong}

ETH Hönggerberg, HCI, G113, CH-8093 Zürich, Switzerland

Now at Paul Scherrer Institut, CH-5232 Villingen PSI, Switzerland

\section{Erik H. Hauri}

Department of Terrestrial Magnetism, Carnegie Institution of Washington, 5241 Broad Branch Road, Washington, DC 20015, USA

\section{Heidi E. Höfer and Yann Lahaye}

Universität Frankfurt, Senckenberganlage 28, D-60054 Frankfurt, Germany

\section{Kersten Horz}

Universität Kiel, Olshausenstr. 40, D-24098 Kiel, Germany

\section{Dorrit E. Jacob}

Universität Greifswald, F.-L. Jahnstr. 17a, D-17487 Greifswald, Germany

Now at Universität Mainz, D-55099 Mainz, Germany

\section{Simone A. Kasemann}

University of Edinburgh, West Mains Road, Edinburgh EH9 3JW, UK

\section{Adam J. R. Kent}

Department of Geosciences, Oregon State University, 104 Wilkinson Hall, Corvallis, Oregon 97331-5506, USA

\section{Thomas Ludwig and Thomas Zack}

Universität Heidelberg, Im Neuenheimer Feld 236, D-69120 Heidelberg, Germany

\section{Paul R. D. Mason}

Utrecht University, Budapestlaan 4, 3584 CD Utrecht, Netherlands

\section{Anette Meixner and Martin Rosner}

GeoForschungsZentrum Potsdam, Telegrafenberg 1, D-14473 Potsdam, Germany

\section{Keiji Misawa}

National Institute of Polar Research, 9-10, Kaga 1-chome, Itabashi-ku, Tokyo 173-8515, Japan

\section{Barbara P. Nash}

University of Utah, 135 South 1460 East, Salt Lake City, Utah 84111, USA

\section{Jörg Pfänder}

Max-Planck-Institut für Chemie, Postfach 3060, D-55020 Mainz, Germany

Now at Technische Universität Bergakademie Freiberg, Akademiestr. 6, D-09599 Freiberg, Germany 


\section{Wayne R. Premo}

U.S. Geological Survey, MS 963, Box 25046, Denver, Colorado 80225-0046, USA

\section{Weidong D. Sun}

Max-Planck-Institut für Chemie, Postfach 3060, D-55020 Mainz, Germany

Now at Guangzhou Institute of Geochemistry, Chinese Academy of Sciences, Guangzhou 510640, China

\section{Massimo Tiepolo}

C.N.R.-Istituto di Geoscienze e Georisorse (I.G.G.) Sezione di Pavia, Via Ferrata 1, I-27100 Pavia, Italy

\section{Riccardo Vannucci}

Università di Pavia, via Ferrata 1, I-27100 Pavia, Italy

Torsten Vennemann

Universität Tübingen, Wilhelmstr. 56, D-72074 Tübingen, Germany

Now at Université de Lausanne, BFSH-2, CH-1015 Lausanne, Switzerland

\section{Dave Wayne}

Los Alamos National Laboratory, Los Alamos, New Mexico 87545, USA

\section{Jon D. Woodhead}

University of Melbourne, Melbourne, Victoria, 3010, Australia

[1] We present new analytical data of major and trace elements for the geological MPI-DING glasses KL2-G, ML3B-G, StHs6/80-G, GOR128-G, GOR132-G, BM90/21-G, T1-G, and ATHO-G. Different analytical methods were used to obtain a large spectrum of major and trace element data, in particular, EPMA, SIMS, LA-ICPMS, and isotope dilution by TIMS and ICPMS. Altogether, more than 60 qualified geochemical laboratories worldwide contributed to the analyses, allowing us to present new reference and information values and their uncertainties (at 95\% confidence level) for up to 74 elements. We complied with the recommendations for the certification of geological reference materials by the International Association of Geoanalysts (IAG). The reference values were derived from the results of 16 independent techniques, including definitive (isotope dilution) and comparative bulk (e.g., INAA, ICPMS, SSMS) and microanalytical (e.g., LA-ICPMS, SIMS, EPMA) methods. Agreement between two or more independent methods and the use of definitive methods provided traceability to the fullest extent possible. We also present new and recently published data for the isotopic compositions of $\mathrm{H}, \mathrm{B}, \mathrm{Li}, \mathrm{O}, \mathrm{Ca}, \mathrm{Sr}, \mathrm{Nd}, \mathrm{Hf}$, and $\mathrm{Pb}$. The results were mainly obtained by high-precision bulk techniques, such as TIMS and MC-ICPMS. In addition, LA-ICPMS and SIMS isotope data of $\mathrm{B}, \mathrm{Li}$, and $\mathrm{Pb}$ are presented.

Components: 20,195 words, 5 figures, 21 tables, 1 dataset.

Keywords: MPI-DING glasses; reference values; isotopes; in situ microanalysis.

Index Terms: 1040 Geochemistry: Radiogenic isotope geochemistry; 1065 Geochemistry: Major and trace element geochemistry; 1094 Geochemistry: Instruments and techniques.

Received 29 June 2005; Revised 10 October 2005; Accepted 3 November 2005; Published 15 February 2006.

Jochum, K. P., et al. (2006), MPI-DING reference glasses for in situ microanalysis: New reference values for element concentrations and isotope ratios, Geochem. Geophys. Geosyst., 7, Q02008, doi:10.1029/2005GC001060.

\section{Introduction}

[2] Jochum et al. [2000] prepared eight geological (MPI-DING) glasses of different natural composi- tion for the purpose of providing reference materials for geochemical, in situ microanalytical work. The samples cover the entire spectrum from ultramafic to highly siliceous composition and comprise 
Table 1. Abbreviations of Analytical Techniques

\begin{tabular}{ll}
\hline \multicolumn{1}{c}{ Abbreviation } & \multicolumn{1}{c}{ Analytical Technique } \\
\hline EPMA & electron probe microanalysis \\
FTIR & Fourier transform infrared spectroscopy \\
ICP-AES & inductively coupled plasma-atomic emission spectroscopy \\
ICPMS & inductively coupled plasma mass spectrometry \\
ID & isotope dilution \\
ID-ICPMS & isotope dilution by inductively coupled plasma mass spectrometry \\
ID-MC-ICPMS & isotope dilution by multiple collector - inductively coupled plasma mass spectrometry \\
ID-MIC-SSMS & isotope dilution by multiple ion counting - spark source mass spectrometry \\
ID-SSMS & isotope dilution by spark source mass spectrometry \\
ID-TIMS & isotope dilution by thermal ionization mass spectrometry \\
INAA & instrumental neutron activation analysis \\
LA-ICPMS & laser ablation - inductively coupled plasma mass spectrometry \\
LA-MC-ICPMS & laser ablation - multiple collector - inductively coupled plasma mass spectrometry \\
LIMS & laser plasma ionization mass spectrometry \\
MC-ICPMS & multiple collector - inductively coupled plasma mass spectrometry \\
MIC-SSMS & multiple ion counting - spark source mass spectrometry \\
MS & mass spectrometry \\
PIXE & proton induced X-ray emission \\
SIMS & secondary ionization mass spectrometry \\
SR-XRF & synchrotron radiation induced X-ray fluorescence \\
SSMS & spark source mass spectrometry \\
TIMS & thermal ionization mass spectrometry \\
TOF-SIMS & time of flight - secondary ionization mass spectrometry \\
XRF & X-ray fluorescence \\
&
\end{tabular}

two basalts (KL2-G, ML3B-G), an andesite (StHs6/80-G), two komatiites (GOR128-G, GOR132-G), a peridotite (BM90/21-G), a rhyolite (ATHO-G) and a quartz-diorite (T1-G). They were analyzed by different bulk and microanalytical methods in various laboratories to obtain preliminary reference values for more than 60 elements. In this paper, numerous abbreviations referring to analytical techniques are used. Table 1 gives an explanation for readers not familiar with these abbreviations.

[3] The MPI-DING glasses found broad acceptance in microanalytical laboratories. Most laboratories use them for calibration of their microanalytical techniques. The komatiite glass GOR132-G was the external reference material for the determination of rare-earth element concentrations in clinopyroxene by SIMS [Hellebrand et al., 2001, 2002; Hellebrand and Snow, 2003; Rankenburg et al., 2004]. Other MPI-DING glasses were also used for calibration of SIMS instruments [Kelley et al., 2003; Johnston and Schwab, 2004; Kita et al., 2004]. The samples were used as reference materials for $\mathrm{B}, \mathrm{Al}$ and $\mathrm{Mg}$ analyses of extraterrestrial materials by SIMS, EPMA and ICPMS [Hoppe et al., 2001; Mostefaoui et al., 2002]. EPMA major element data of mid-ocean ridge basalts and glass shards have been calibrated with MPI-DING glasses by Grevemeyer et al. [2002], Horz et al.
[2004], and Klein et al. [2004]. The accuracy of microscopic synchrotron induced XRF ( $\mu$ SR-XRF) was verified by analyzing a series of MPI-DING glasses [Smit et al., 2004]. Data accuracy and precision of LA-ICPMS were monitored by analyses of StHS6/80-G [Straub et al., 2004]. Quantification of LA-ICPMS measurements of impurities in glass fibers was performed using the basalt glasses KL2-G and ML3B-G for calibration [Becker et al., 2002].

[4] Some laboratories also use the MPI-DING glasses for their fundamental research in microanalysis. Kempenaers et al. [2003] investigated the degree of micro-heterogeneity of some MPIDING glasses using $\mu$-SR-XRF. Rodushkin et al. [2002], Becker et al. [2002], and Stoll et al. [2003] investigated the matrix-dependent response variations in LA-ICPMS. The potential for high lateral resolution analyses when using sector field instruments for direct sampling was demonstrated with GOR128-G by Latkoczy and Günther [2002].

[5] Since the publication of Jochum et al. [2000] many laboratories have provided new major element and trace element data of the MPI-DING glasses. Because there is also an increasing need for isotopic information, the determination of the isotopic composition of stable and radiogenic iso- 
topes in the reference glasses is now in progress. Some of these new trace element and isotope results have been recently published, e.g., Becker et al. [2000]; Guillong et al. [2002]; Weyer et al. [2002]; Raczek et al. [2003]; Canil et al. [2003]; Badanina et al. [2004]; Liu and O'Neill [2004]; Villaseca et al. [2003]; Willbold and Jochum [2005]; Rosner and Meixner [2004]; and Jochum et al. [2005a, 2005b].

[6] Twenty-five laboratories were involved to establish preliminary reference values for about 60 major and trace elements of the MPI-DING glasses [Jochum et al., 2000]. The concentration values for many elements were well established (e.g., major elements, $\mathrm{Sr}, \mathrm{Ba}$, rare earth elements (REE)), others (e.g., $\mathrm{Cl}, \mathrm{Bi}, \mathrm{As}, \mathrm{Se}, \mathrm{Br}$ ) were only for information because of the few analytical data available. For some elements (S, Tl, F) no data existed.

[7] During the last five years many new laboratories were invited to analyze the glasses, mainly using EPMA for major elements, and isotope dilution mass spectrometry, SIMS, ICPMS and LA-ICPMS for trace elements.

[8] The aim of this paper is to present new trace and major element results of the MPI-DING glasses, to determine reference values and their uncertainties by following the IAG recommendations for certification of geological reference materials [Kane et al., 2003] and to present new results of the isotopic compositions of $\mathrm{H}, \mathrm{B}, \mathrm{Li}, \mathrm{O}, \mathrm{Ca}, \mathrm{Sr}$, $\mathrm{Nd}$, Hf and $\mathrm{Pb}$. All data given in this publication can also be found in the GeoReM database (http:// georem.mpch-mainz.gwdg.de).

\section{Analytical Techniques}

\subsection{Major and Trace Elements}

[9] In the following, procedures and most important features of the techniques used in this paper are described briefly. Table 2 lists the codes (C) identifying laboratories, analysts and techniques. Descriptions of the techniques for $\mathrm{C}=1-27$ have been published earlier by Jochum et al. [2000].

\subsubsection{Electron Probe Microanalysis (EPMA)}

[10] This technique was used by 14 laboratories to provide data for the major element compositions of the MPI-DING glasses. Table 3 lists a compilation of the analytical details of the electron microprobe analyses of this work, Jochum et al. [2000], and two recent publications [Liu and O'Neill, 2004; Badanina et al., 2004].

\subsubsection{Isotope Dilution by Thermal Ionization Mass Spectrometry (ID-TIMS)}

[11] The abundances of $\mathrm{Pb}, \mathrm{Th}$ and $\mathrm{U}$ in the Hawaiian basalt glasses KL2-G and ML3B-G were determined at USGS Denver $(\mathrm{C}=53)$ by isotope dilution using a thermal ionization mass spectrometer.

[12] The glasses were crushed in stainless steel mortar and pestle. Fractions for analysis were transferred to a PFA Teflon vial for dissolution in ultrapure conc. $\mathrm{HF}+\mathrm{HNO}_{3}$, and heated. Later on they were spiked with a mixed ${ }^{233} \mathrm{U}_{-}{ }^{236} \mathrm{U}_{-}{ }^{230} \mathrm{Th}^{205} \mathrm{~Pb}$ tracer solution and again heated to achieve equilibration. Lead was separated first using an anion exchange column in an $\mathrm{HBr}$ solution and then $\mathrm{U}$ and $\mathrm{Th}$ in an $\mathrm{HNO}_{3}$ solution. Analytical blanks for the procedure ranged from 1 to $4 \mathrm{pg}$ each for total $\mathrm{U}$ and $\mathrm{Th}$, and were $37 \mathrm{pg}$ for total $\mathrm{Pb}$. Isotopic compositions of U-Th-Pb were measured on a VG Isomass 54R equipped with an ion counting system and the data acquisition ANALYST programming of Ludwig [1994], and reduced using PBDAT programming [Ludwig, 1993].

\subsubsection{Inductively Coupled Plasma-Atomic Emission Spectroscopy (ICP-AES)}

[13] At the GeoForschungsZentrum Potsdam $(\mathrm{C}=$ 33) boron concentrations of three MPI-DING glasses were determined by ICP-AES using a Varian Liberty 200 instrument. Between $260 \mathrm{mg}$ and $130 \mathrm{mg}$ of the powdered glass reference materials were fluxed with $\mathrm{K}_{2} \mathrm{CO}_{3}$ and boron was chemically separated by cation exchange chromatography using AG 50W-X8 resin as described by Kasemann et al. [2001]. The boron recovery for the entire chemical procedure was 95\%. Calibration was typically made using a $1 \mu \mathrm{g} \mathrm{m}{ }^{-1}$ boron standard solution in $0.05 \mathrm{M} \mathrm{HCl}$. To guarantee precise and reproducible analytical results the boron concentrations in the sample solution were kept between 0.1 and $1 \mu \mathrm{g} \mathrm{g}^{-1}$.

\subsubsection{Inductively Coupled Plasma Mass Spectrometry (ICPMS)}

[14] The MPI-DING glasses were cleaned in an ultrasonic bath with deionized water, digested in $\mathrm{HF}$, evaporated to dryness, and consecutively dissolved in aqua regia and $\mathrm{HClO}_{4}$ before being taken up in $2 \% \mathrm{HNO}_{3}$. The solutions were then analyzed using the upgraded VG PlasmaQuad ICPMS at the 

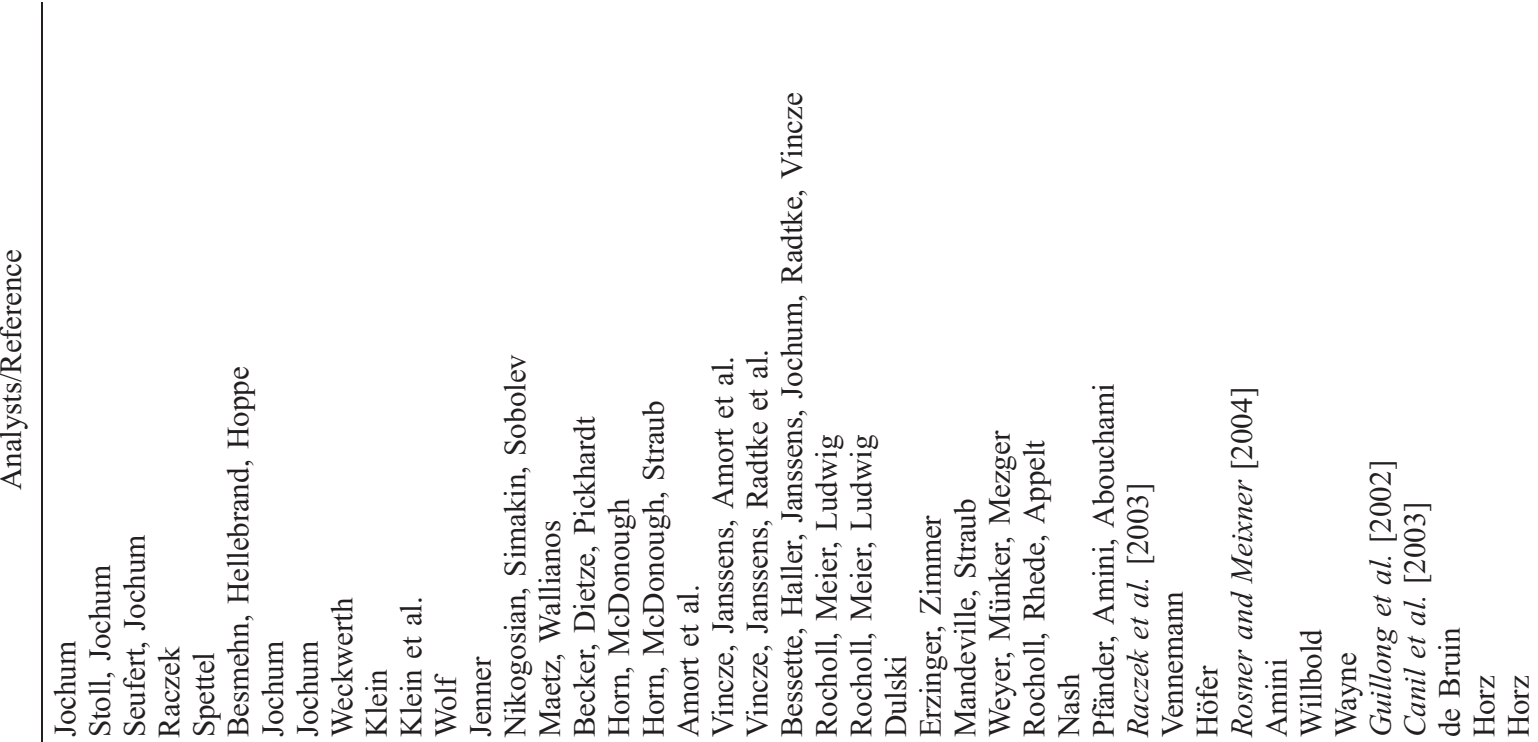

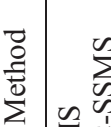

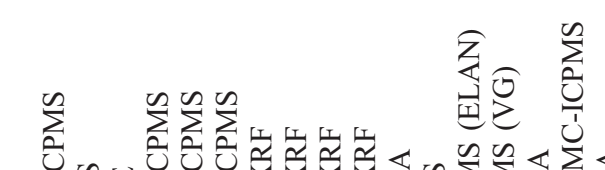
$n$

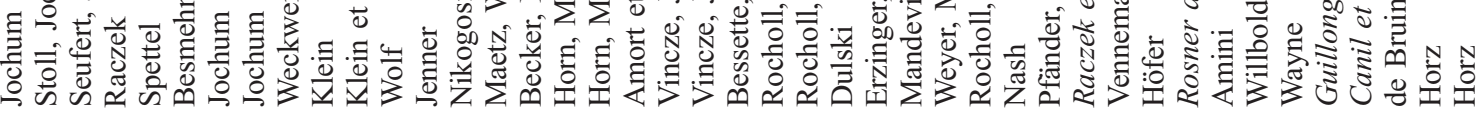

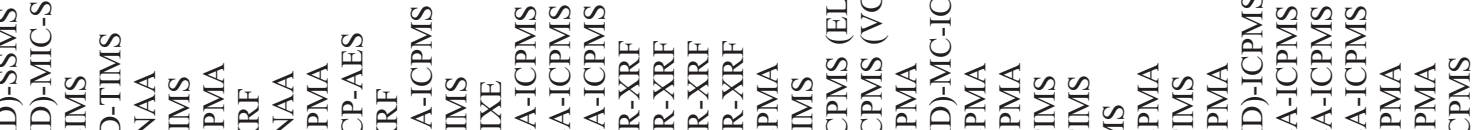

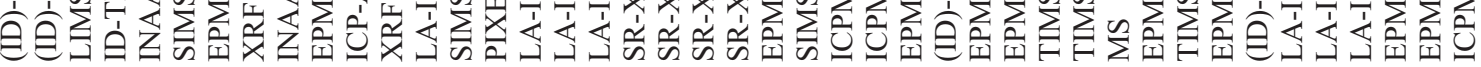

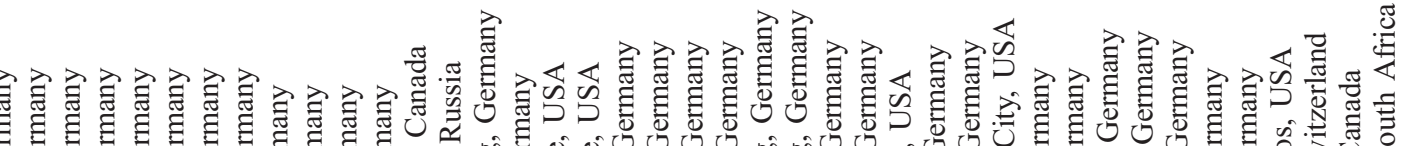

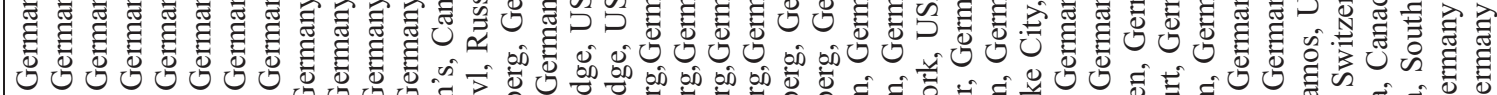

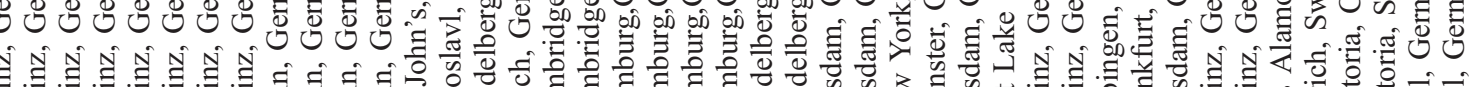

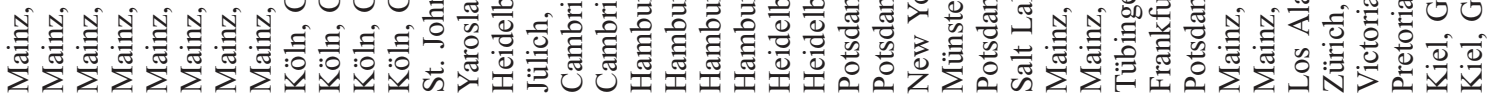

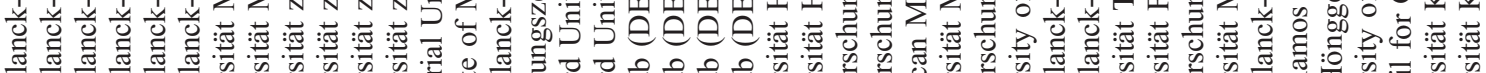

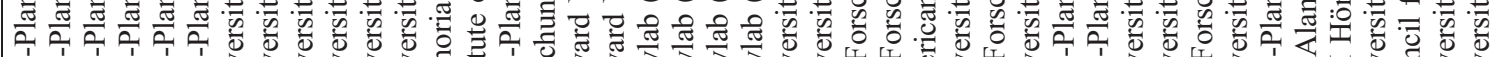

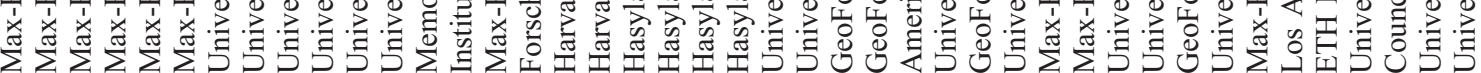




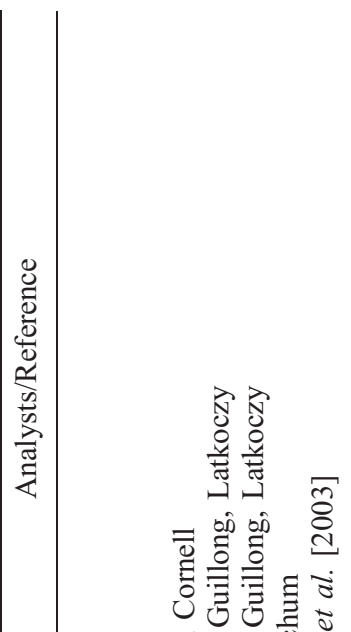

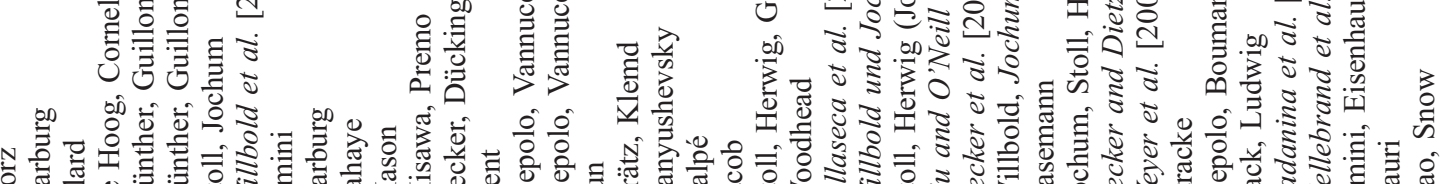

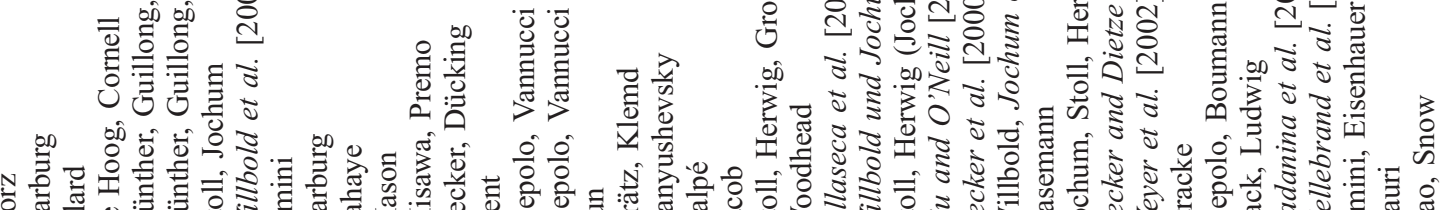

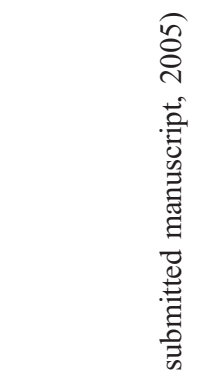

$\widehat{\overbrace{}}$

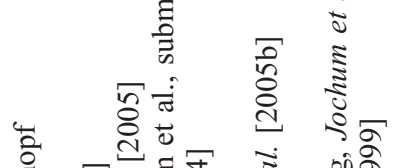

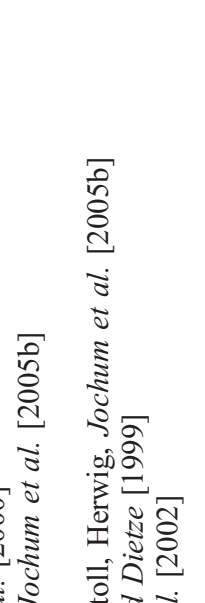

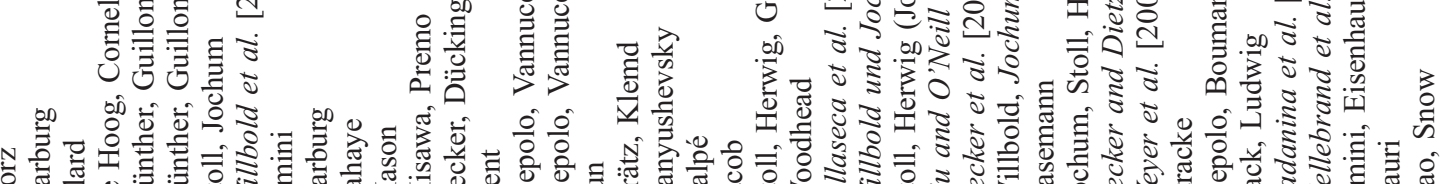

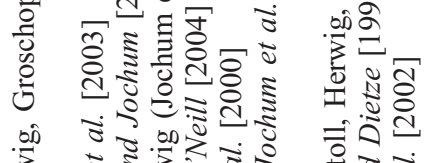

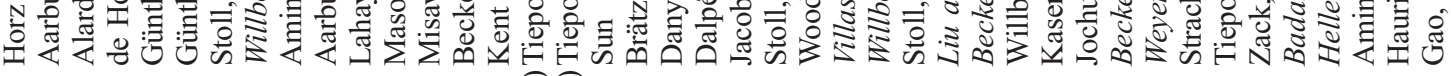

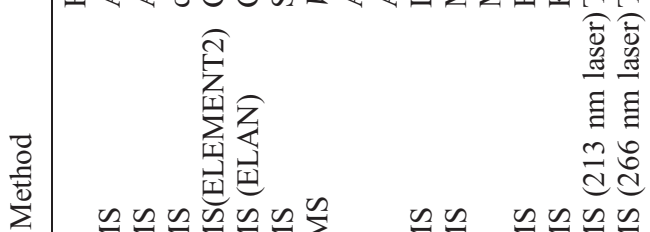

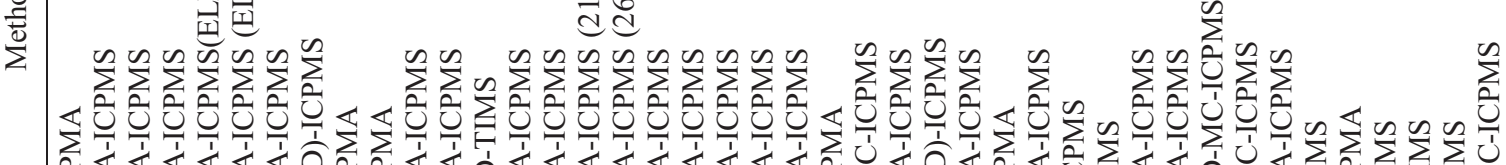

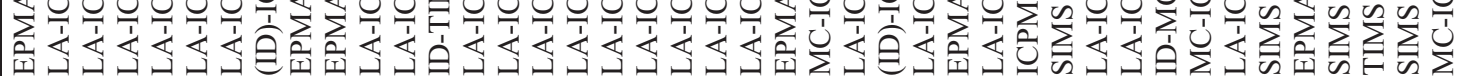

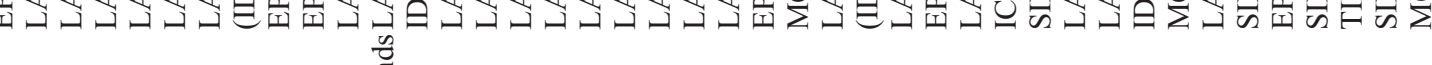

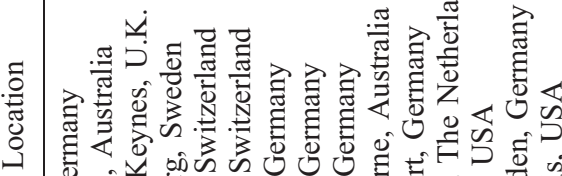

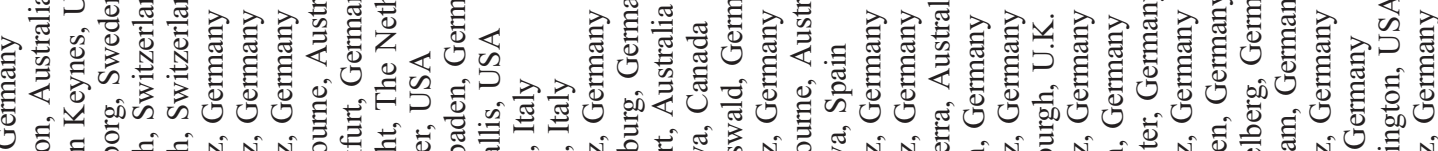
○

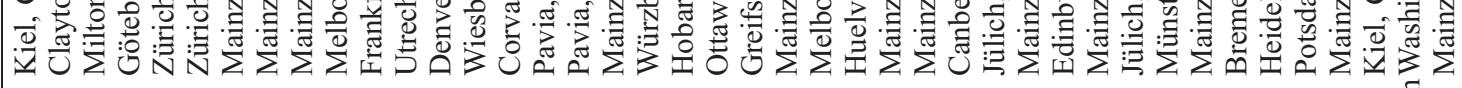

壱

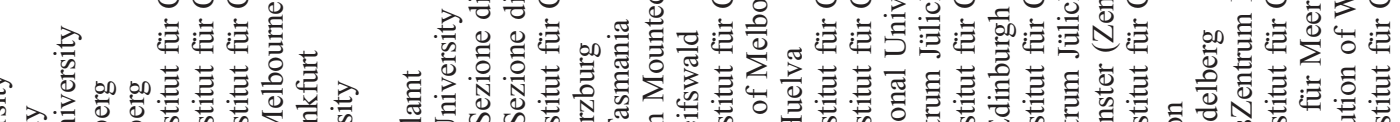

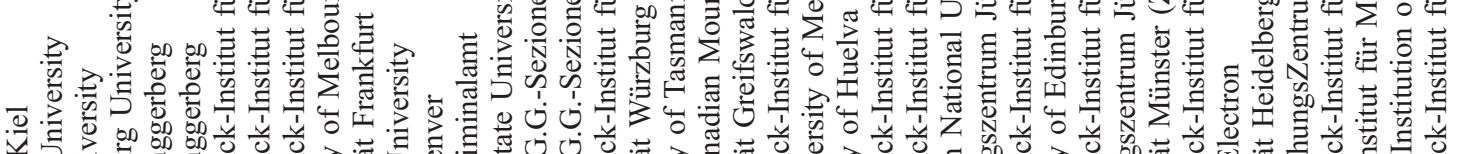

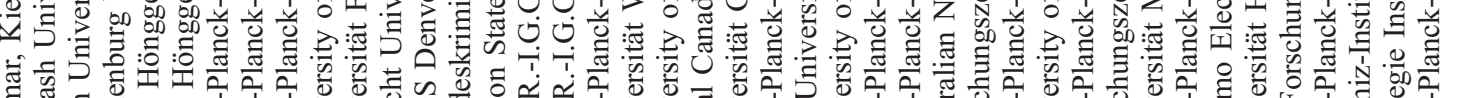

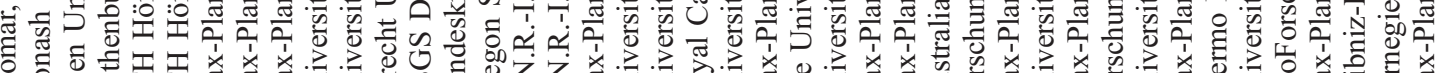

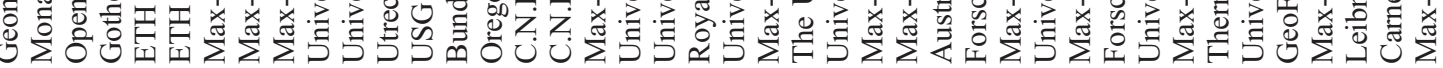

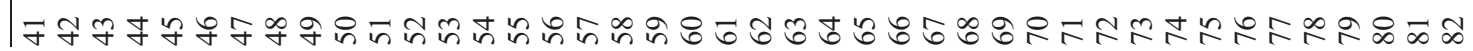



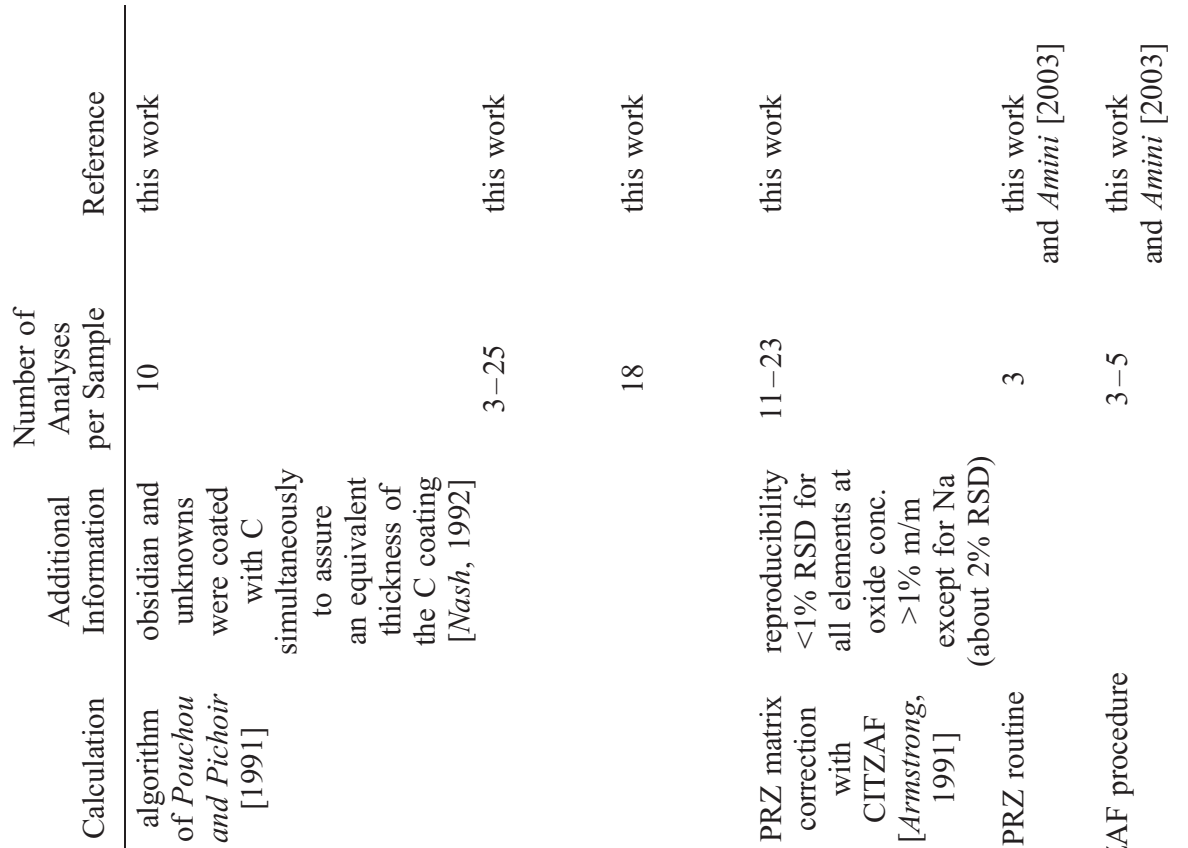

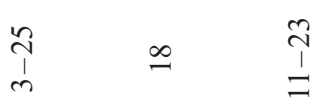

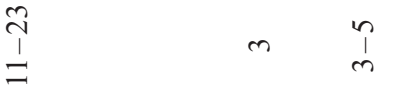

n

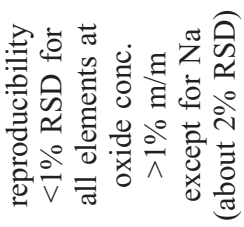

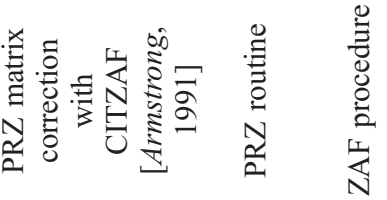

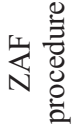

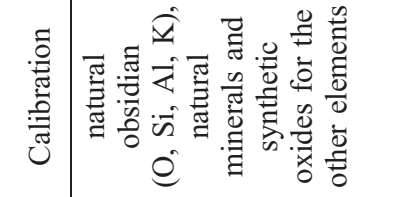

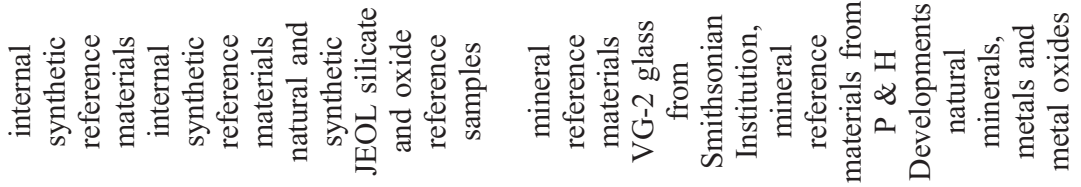

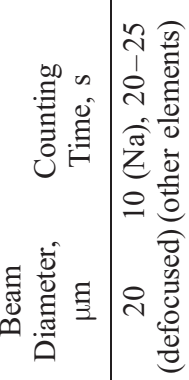

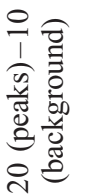

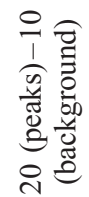

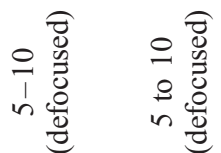

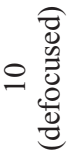

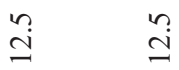

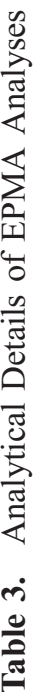

$\because$ n

iq
i
i

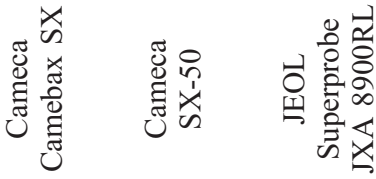

字

$\begin{array}{ll}\stackrel{9}{1} & \text { q } \\ & n\end{array}$

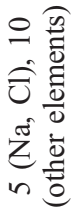

$\begin{array}{ll}\stackrel{0}{0} & \\ 0 & 0 \\ 0 & 0 \\ 0 & 1 \\ \frac{0}{0} & n \\ \text { d } & n\end{array}$

in

으

으

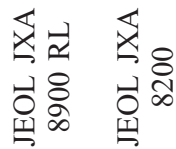

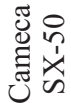

$n$
$\dot{q}$

요

: 


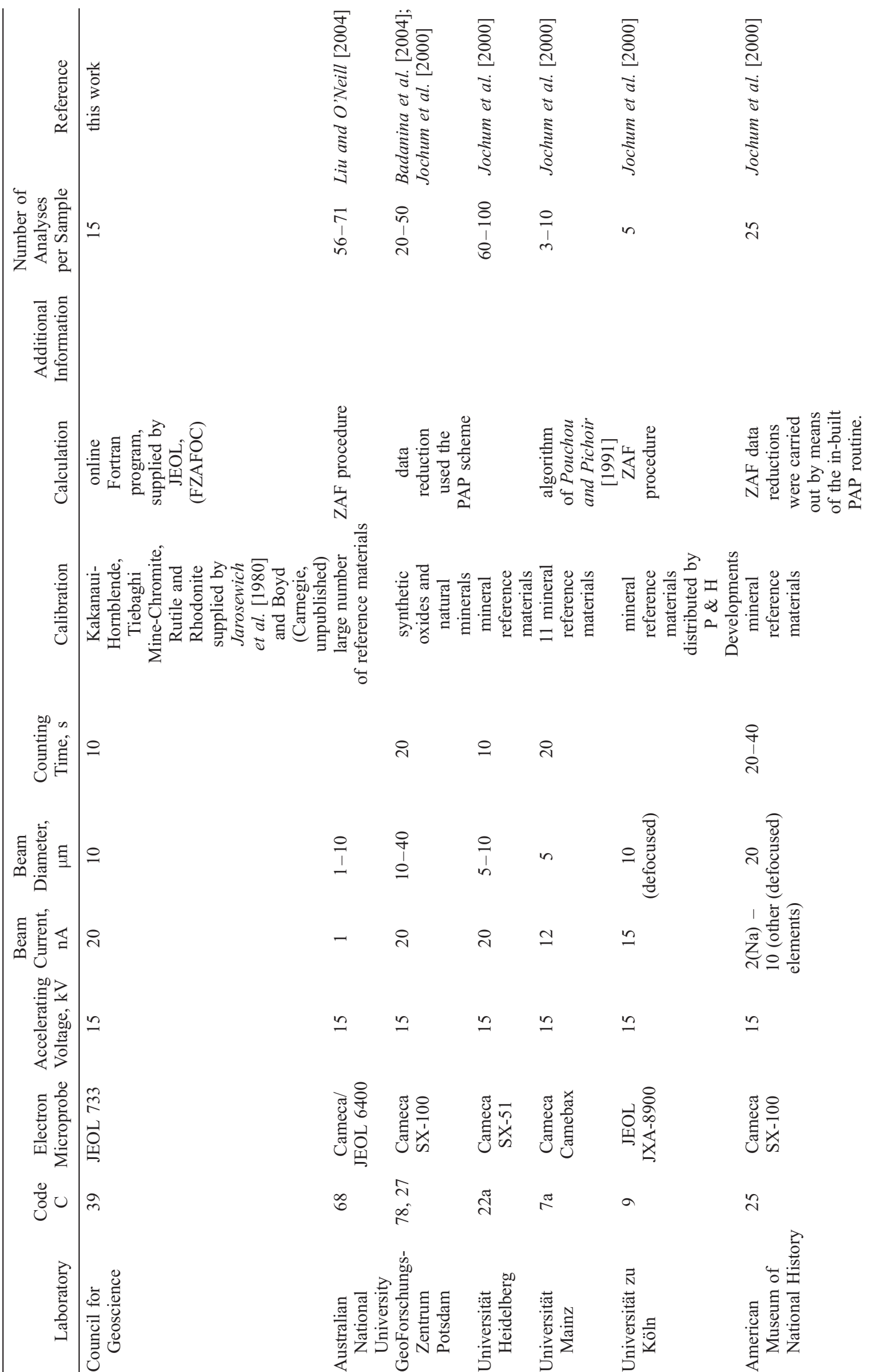


University of Kiel $(\mathrm{C}=40)$ following the procedure outlined by Garbe-Schönberg [1993]. Various standard solutions were used for calibration. Accuracy was checked against international reference materials [Govindaraju, 1994] and was generally better than $5 \%$.

\subsubsection{Multiple Collector-ICPMS (MC-ICPMS)}

[15] Lithium concentrations were determined at the Max-Planck-Institut für Chemie, Mainz $(\mathrm{C}=82)$ by standard bracketing on a $\mathrm{Nu}$ Instruments multicollector ICP-MS following standard separation techniques [Jeffcoate et al., 2004] (cf. description of isotope methods, this study). The lithium recovery was near $100 \%$. Estimated accuracy based on analysis of reference materials is better than $10 \%$.

\subsubsection{Multielement Isotope Dilution by Inductively Coupled Plasma-Mass Spectrometry (ID-ICPMS)}

[16] High-precision measurements were performed at the Max-Planck-Institut für Chemie Mainz $(\mathrm{C}=35,48,66)$ using a recently developed multielement isotope dilution ID-ICPMS method [Willbold et al., 2003; Willbold and Jochum, 2005]. After the addition of multielement spike solutions, about $100 \mathrm{mg}$ of the samples were dissolved using $\mathrm{HF}$ and $\mathrm{HNO}_{3}$. To correct for mass discrimination effect during measurement a Ru-Re solution was added. The measurements were carried out on a ThermoFinnigan Element 2 double-focusing sector field mass spectrometer. Interferences of polyatomic ions have been avoided by using the high resolution mode of this instrument. Concentrations of 12 trace elements were determined by ID and the overall analytical uncertainty for the ID data is $1-2 \%$. The ID-determined trace elements were used as internal standards for the determination of further 14 (mainly mono-isotopic) trace elements by external calibration by using relative sensitivity factors. The combined standard uncertainty for these data is about $2-3 \%$. ID-ICPMS data for BCR-1, BHVO-1, OU-6, NIST SRM 612 agree with the reference values within about $3 \%$ [Willbold and Jochum, 2005].

\subsubsection{Isotope Dilution by Multiple Collector-ICPMS (ID-MC-ICPMS)}

[17] New precise and accurate isotope dilution data for Hf and Ta have been published by Weyer et al. [2002]. Analyses were performed on a Micromass Isoprobe MC-ICP mass spectrometer in the Zentral- labor für Geochronologie, Universität Münster, Germany $(\mathrm{C}=74)$. Uncertainties are about $1 \%$ for $\mathrm{Hf}$ and $3-5 \%$ for Ta depending on the concentration.

\subsubsection{Secondary Ionization Mass Spectrometry (SIMS)}

[18] Lithium concentrations were determined at the University of Edinburgh $(\mathrm{C}=71)$ using the Cameca ims 4f ion microprobe. Analytical details are given in section 3.3. Measured lithium concentration was normalized to the NIST SRM 610 reference material using the recommended values from Pearce et al. [1997]. The analytical uncertainty for Li determination is less than $5 \%$.

[19] $\mathrm{Li}, \mathrm{Be}$ and $\mathrm{B}$ concentrations were determined at the Universität Heidelberg $(\mathrm{C}=77)$ using a Cameca ims $3 \mathrm{f}$ secondary ion mass spectrometer. The procedure of Marschall and Ludwig [2004] was followed for this study in order to minimize the influence of surface contamination. Analyses were performed using a $14.5 \mathrm{keV} / 30 \mathrm{nA}{ }^{16} \mathrm{O}^{-}$ primary ion beam. Positive secondary ions were nominally accelerated to $4.5 \mathrm{keV}$ (energy window set to $40 \mathrm{eV}$ ) and an energy filtering technique with an offset of $75 \mathrm{eV}$ at $\mathrm{m} / \Delta \mathrm{m}(10 \%)$ of ca. 1000 was used. Secondary ion intensities were collected using a $750-\mu \mathrm{m}$ field aperture (translating to an imaged field of ca. $15 \mu \mathrm{m}$ on the sample surface). Count rates for ${ }^{7} \mathrm{Li}$, ${ }^{9} \mathrm{Be}$ and ${ }^{11} \mathrm{~B}$ were normalized to the count rate of ${ }^{30} \mathrm{Si}$. Relative ion yields were calibrated with the NIST SRM 610 glass using the Pearce et al. [1997] recommended values. Five spots of the four analyzed MPI-DING glasses were measured. The overall uncertainty is dominated by possible matrix effects [Ottolini et al., 1993].

[20] $\mathrm{H}_{2} \mathrm{O}, \mathrm{CO}_{2}, \mathrm{~F}, \mathrm{~S}$ and $\mathrm{Cl}$ concentrations were determined at the Carnegie Institution of Washington $(\mathrm{C}=81)$ using a Cameca IMS6F ion probe, following the methods described by Hauri et al. [2002] and Koga et al. [2003]. A primary beam of $8 \mathrm{nA} \mathrm{Cs}^{+}$ions was used and negative secondary ions were analyzed at $5 \mathrm{keV}( \pm 50 \mathrm{eV})$ at a mass resolving power of 2400 ( $10 \%$ definition) with electron-gun charge compensation and no energy filtering. Glass grains were mounted into indium inside an Al-metal disk, and the operating vacuum was $7 \times 10^{-10}$ torr or better. A single mm-sized grain of each glass was analyzed five times, and the average and reproducibility of the five analyses is reported. Detection limits for the analytical session were $0.0016 \% \mathrm{~m} / \mathrm{m} \mathrm{H}_{2} \mathrm{O},<3 \mu \mathrm{g} / \mathrm{g} \mathrm{CO}_{2}$, and $<0.5 \mu \mathrm{g} / \mathrm{g} \mathrm{F}, \mathrm{S}$ and $\mathrm{Cl}$ as determined by multiple analyses of a synthetic forsterite with $0.00004 \%$ 
$\mathrm{m} / \mathrm{m} \mathrm{H}_{2} \mathrm{O}$ (see Koga et al. [2003] for details). Multiple analyses of ultra-pure $\mathrm{Herasil} \mathrm{SiO}_{2}$ glass gave similar detection limits except for $\mathrm{H}_{2} \mathrm{O}$ $(0.0088 \% \mathrm{~m} / \mathrm{m})$ and $\mathrm{Cl}(0.8 \mu \mathrm{g} / \mathrm{g})$ which are real concentrations resolved from the detection limits. Calibration drift was non-existent, as monitored by interspersed analyses of MORB glass ALV519-4-1 $(\mathrm{n}=14)$; this glass gave concentrations of $0.224 \%$ $\mathrm{m} / \mathrm{m} \mathrm{H}_{2} \mathrm{O}( \pm 11 \% 2 \sigma), 143 \mu \mathrm{g} / \mathrm{g} \mathrm{CO}_{2}( \pm 3.2 \% 2 \sigma)$, $113 \mu \mathrm{g} / \mathrm{g} \mathrm{F}( \pm 3.7 \% 2 \sigma), 831 \mu \mathrm{g} / \mathrm{g} \mathrm{S}( \pm 5 \% 2 \sigma)$ and $43.8 \mu \mathrm{g} / \mathrm{g} \mathrm{Cl}( \pm 5.7 \% 2 \sigma)$. This level of reproducibility is typical for most glasses, including the MPI-DING glasses measured in this study. During our analytical session, we also obtained data for the NIST glasses SRM610 $\left(0.0127 \% \mathrm{~m} / \mathrm{m} \mathrm{H}_{2} \mathrm{O}\right.$, $2.2 \mu \mathrm{g} / \mathrm{g} \mathrm{CO}_{2}, 413 \mu \mathrm{g} / \mathrm{g} \mathrm{F}, 693 \mu \mathrm{g} / \mathrm{g} \mathrm{S}, 438 \mu \mathrm{g} / \mathrm{g}$ $\mathrm{Cl})$, SRM $612\left(0.021 \% \mathrm{~m} / \mathrm{m} \mathrm{H}_{2} \mathrm{O}, 2.8 \mu \mathrm{g} / \mathrm{g} \mathrm{CO}_{2}\right.$, $62 \mu \mathrm{g} / \mathrm{g} \mathrm{F}, 350 \mu \mathrm{g} / \mathrm{g} \mathrm{S}, 131 \mu \mathrm{g} / \mathrm{g} \mathrm{Cl})$ and SRM614 $\left(0.0186 \% \mathrm{~m} / \mathrm{m} \mathrm{H}_{2} \mathrm{O}, 4.0 \mu \mathrm{g} / \mathrm{g} \mathrm{CO}_{2}, 10 \mu \mathrm{g} / \mathrm{g} \mathrm{F}\right.$, $306 \mu \mathrm{g} / \mathrm{g} \mathrm{S}, 92 \mu \mathrm{g} / \mathrm{g} \mathrm{Cl}$ ) with $2 \sigma$ reproducibilities from $1 \%$ to $7 \%$.

[21] For $\mathrm{H}_{2} \mathrm{O}$ and $\mathrm{CO}_{2}$, the SIMS calibration utilized reference glasses whose $\mathrm{H}_{2} \mathrm{O}$ contents were determined by both manometry and FTIR. Concentrations of $\mathrm{F}, \mathrm{S}$ and $\mathrm{Cl}$ in reference glasses were determined by EPMA from multiple laboratories. Interlaboratory biases have been examined and eliminated for all SIMS calibration materials. Considering possible matrix effects and errors on calibration slopes, we determine that the combined uncertainties (reproducibility and accuracy) are $15 \%$ for $\mathrm{H}_{2} \mathrm{O}$ and $10 \%$ for $\mathrm{CO}_{2}, \mathrm{~F}, \mathrm{~S}$ and $\mathrm{Cl}$.

[22] Some SIMS trace element data of the MPIDING glasses have been determined using an upgraded Cameca ims-3f ion microprobe at the Max-Planck-Institut für Chemie Mainz $(\mathrm{C}=79)$.

\subsubsection{Laser Ablation-Inductively Coupled Plasma-Mass Spectrometry (LA-ICP-MS)}

[23] This method was used in many different laboratories for multielement analyses of the MPI-DING glasses. Altogether 23 LA-ICPMS laboratories were involved in the trace element investigations using different laser ablation systems $(266 \mathrm{~nm}, 213 \mathrm{~nm}$ $\mathrm{Nd}: Y A G$, and $193 \mathrm{~nm}$ ArF excimer lasers) and ICP mass spectrometers (quadrupole, sector field instruments). Table 4 lists the instruments and analytical conditions used in the different laboratories.

\subsection{Isotopic Analyses}

[24] Different laboratories provided data of the isotopic compositions of $\mathrm{H}, \mathrm{Li}, \mathrm{B}, \mathrm{O}, \mathrm{Ca}, \mathrm{Sr}, \mathrm{Nd}$, $\mathrm{Hf}$ and $\mathrm{Pb}$. The results were obtained from high precision techniques using large sample amounts and from microanalytical techniques.

\subsubsection{Hydrogen Isotope and Water Analyses}

[25] At the University of Tübingen $(\mathrm{C}=31)$ the water content and hydrogen isotope composition of the MPI-DING glasses StHs6/80-G and T1-G were measured according to a method adapted after the conventional method of Vennemann and O'Neil [1993]. Prior to the extraction of water, about 300 to $450 \mathrm{mg}$ of the samples were degassed in a high vacuum $\left(<10^{-6} \mathrm{mbar}\right)$ at $110^{\circ} \mathrm{C}$ for about 24 hours. Water was extracted by heating the samples to about $800^{\circ} \mathrm{C}$ (just below the melting point to help facilitate the diffusion of water out of the glass) and held at that temperature for one hour. Thereafter, any remaining water was extracted by melting the sample at temperatures in excess of $1400^{\circ} \mathrm{C}$.

[26] Zinc has been used for the quantitative conversion of $\mathrm{H}_{2} \mathrm{O}$ to $\mathrm{H}_{2}$. The product $\mathrm{H}_{2}$ was analyzed for its isotope composition with a Finnigan MAT 252 mass spectrometer. The reference gas was calibrated using VSMOW (Vienna Standard Mean Ocean Water) and SLAP (Standard Light Antarctic Precipitation). On the basis of replicate analyses of reference materials, the isotopic analyses are precise to within 2 per mil (\%o) 2SD.

[27] The quantity of $\mathrm{H}_{2} \mathrm{O}$ was determined from calibration curves established by injection of variable amounts of an internal water standard into the same extraction line. The precision of the measurement is about $\pm 0.1 \% \mathrm{~m} / \mathrm{m}$.

\subsubsection{Oxygen Isotopes}

[28] The oxygen isotope composition $\left({ }^{16} \mathrm{O},{ }^{17} \mathrm{O}\right.$, ${ }^{18} \mathrm{O}$ ) of the MPI-DING glasses were measured at the University of Tübingen $(\mathrm{C}=31)$ using a method adapted after that described by Rumble and Hoering [1994]. Between 1 to $3 \mathrm{mg}$ of sample was loaded onto a small Pt-sample holder fixed on a stainless steel block and pumped out to a vacuum of less than $10^{-6}$ mbar for a minimum of 2 hours. After prefluorination of the sample chamber with 50 mbars of $\mathrm{F}_{2}$ overnight, the samples were heated with a $25 \mathrm{~W} \mathrm{CO}_{2}$-laser in 50 mbars of pure $\mathrm{F}_{2}$. Excess $\mathrm{F}_{2}$ was separated from the $\mathrm{O}_{2}$ produced by conversion to $\mathrm{Cl}_{2}$ using $\mathrm{KCl}$ held at $150^{\circ} \mathrm{C}$. The extracted $\mathrm{O}_{2}$ was collected on a molecular sieve (13X), desorbed for distillation purposes at -100 to $-110^{\circ} \mathrm{C}$ using an ethanol-liquid nitrogen slush trap and subsequently analyzed as $\mathrm{O}_{2}$ on a 


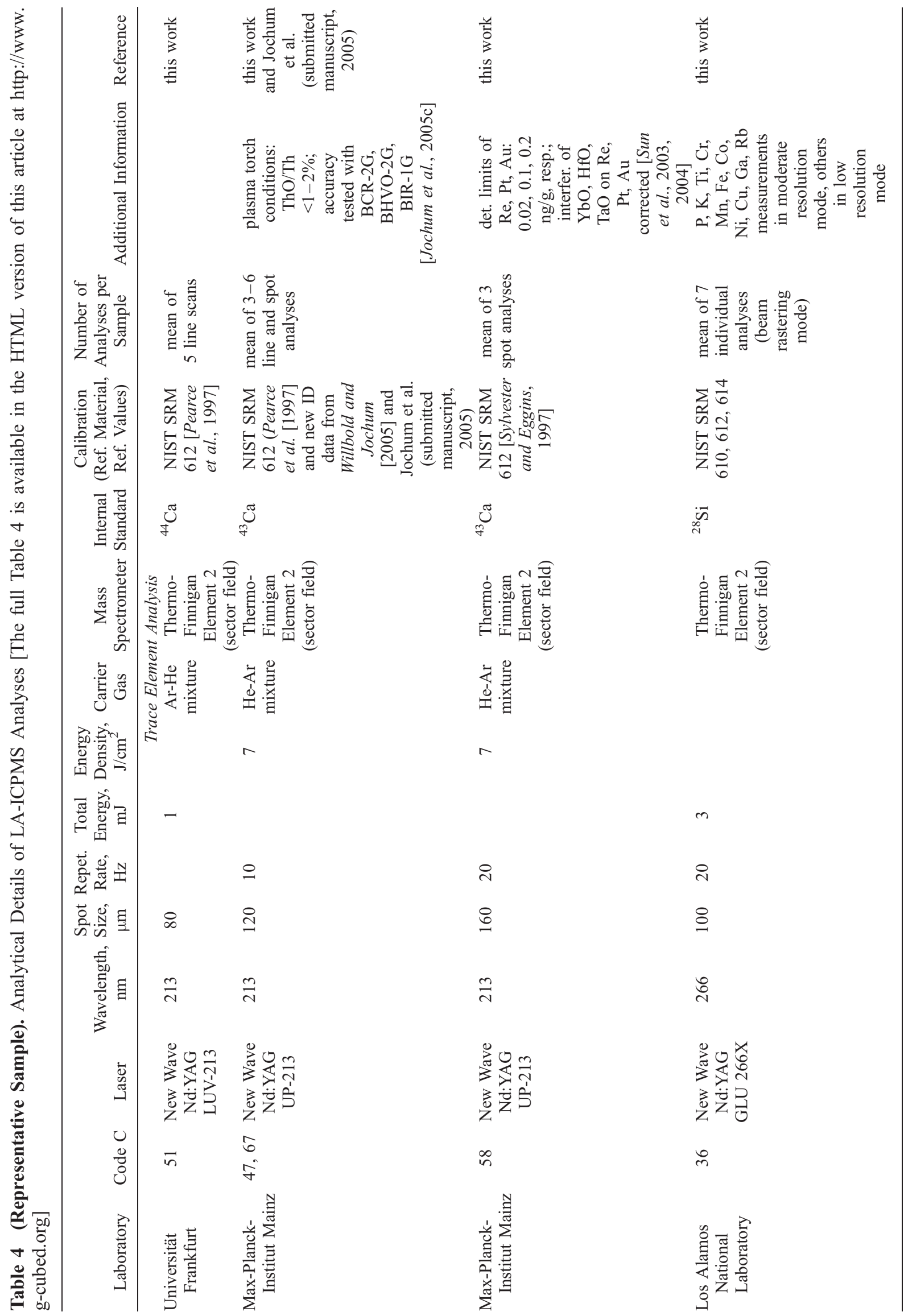


Finnigan MAT 252 mass spectrometer. The isotopic composition of the reference gas $\mathrm{O}_{2}$ has been determined by conversion to $\mathrm{CO}_{2}$ using a Pt-treated graphite rod and measurement of the isotopic composition of $\mathrm{CO}_{2}$ relative to a reference gas calibrated against VSMOW. Accuracy controls were done by analyzing NIST SRM 8546 (NBS 28) quartz.

\subsubsection{Boron Isotopes}

[29] Isotopic compositions of boron were determined by thermal ionization mass spectrometry (TIMS) using the $\mathrm{Cs}_{2} \mathrm{BO}_{2}^{+}$-graphite method at the GeoForschungsZentrum Potsdam $(\mathrm{C}=33)$. A detailed description of the whole analytical procedure has been given by Rosner and Meixner [2004]. Boron was extracted from the glasses by alkaline fusion with $\mathrm{K}_{2} \mathrm{CO}_{3}$ or alternatively by $\mathrm{HF}$ attack in the presence of mannitol. In both cases an aliquot sample solution comprising $3 \mu \mathrm{g}$ boron was separated by sequential ion exchange chromatography. An aliquot comprising $0.5 \mu \mathrm{g}$ boron, mixed with $\mathrm{CsCO}_{2}$ solution (1 mol B: $2 \mathrm{~mol}$ cesium) and mannitol (1 $\mu \mathrm{g}$ B: $40 \mu \mathrm{g}$ mannitol), was loaded on a degassed tantalum filament coated with a graphite/ ethanol slurry and heated at 0.7 A to dryness. Isotope analyses were carried out on a static multicollector Finnigan MAT 262 mass spectrometer equipped with a special double Faraday cup having a fixed spacing for the dicesium metaborate complexes. The boron was detected as $\mathrm{Cs}_{2} \mathrm{BO}_{2}^{+}$ complexes at masses 308 and 309. Running temperatures were $<900^{\circ} \mathrm{C}$. B-isotope ratios are reported as $\delta^{11} \mathrm{~B}$ values, i.e., normalized to the mean of concurrently measured NIST SRM 951 standard solutions:

$\delta^{11} \mathrm{~B}=\left[\left\{{ }^{11} \mathrm{~B} /{ }^{10} \mathrm{~B}\right\}\right.$ sample $\left./\left\{\left\{{ }^{11} \mathrm{~B} /{ }^{10} \mathrm{~B}\right\}_{\text {NIST SRM } 951}-1\right] * 1000\right)$.

Accuracy is controlled by comparison of our $\delta^{11} \mathrm{~B}$ for JB-3, JA-1 and JR-2 [Rosner and Meixner, 2004] with literature data. Within error $(1.1 \%$ o $2 \mathrm{SD})$ our $\delta^{11} \mathrm{~B}$ data overlap the literature values.

[30] The $\delta^{11} \mathrm{~B}$ signature of three MPI-DING glasses (StHs6/80-G, GOR132-G and GOR128-G) has also been determined with laser ablation-multicollector (LA-MC)-ICPMS at Thermo Electron (Bremen) $\mathrm{GmbH}$, Finnigan Advanced Mass Spectrometry, Bremen, Germany $(\mathrm{C}=76)$. Table 4 lists analytical details. Due to the low B content of selected samples the MC-ICPMS was equipped with multiple ion counters instead of the conventional Faraday cups. The "standard-sample-standard" bracketing approach has been chosen to correct for isotope fractionation effects (mass bias, laser induced fractionation and ion counter drift) and in samples with B at the $\mu \mathrm{g} / \mathrm{g}$ level, the method ensures an internal precision of around 2.5\%o (1 RSE). NIST SRM 610 was the external standard reference material and the average value for ${ }^{11} \mathrm{~B} /{ }^{10} \mathrm{~B}$ of 4.049 [Le Roux et al., 2004] was used. Details on the analytical method are reported by Tiepolo et al. [2005a, 2005b].

\subsubsection{Lithium Isotopes}

[31] Lithium isotopes were measured by MCICPMS and SIMS in the Mainz and Edinburgh laboratories, respectively. The data are reported in the conventional $\delta^{7} \mathrm{Li}$ notation relative to LSVEC (NIST SRM 8545).

\subsubsection{MC-ICPMS}

[32] Lithium isotopes were measured by solution MC-ICPMS at the Max-Planck Institut für Chemie $(C=82)$. Sufficient material $(10-60 \mathrm{mg})$ from each glass was used to provide approximately $0.1-$ $1 \mu \mathrm{g}$ of Li. Dissolution and separation were carried out using the technique of Jeffcoate et al. [2004], with the difference that only a single Methanol$\mathrm{HNO}_{3}$ column was used, with tests of pre- and after tail to ensure complete yield. The separation of $\mathrm{Na}$ from $\mathrm{Li}$ was nonetheless quite good, with $\mathrm{Na} / \mathrm{Li}$ ratios in solution in all cases less than 5. Total procedural blank was $40 \mathrm{pg}$. The Li recovery was near $100 \%$.

[33] The solutions were diluted to $100 \mu \mathrm{g} / 1$ for measurement and introduced into the mass spectrometer using a standard CETAC ASX-100 autosampler connected to a CETAC Aridus desolvating nebulizer with an ESI teflon PFA microconcentric nebulizer tip. Solution uptake was nominally $50 \mathrm{microliter} / \mathrm{min}$ and $4.13 \mathrm{l} / \mathrm{min}$ Ar sweep gas. Mass spectrometry was carried out on a standard $\mathrm{Nu}$ Plasma double focusing multicollector ICPMS with variable dispersion ion optics. The ${ }^{6} \mathrm{Li}$ and ${ }^{7} \mathrm{Li}$ beams were measured in the H6 and L5 Faraday collectors at an ion current of 5-7 pA $(5-7 \mathrm{~V}$ with a $10^{12} \mathrm{ohm}$ resistor, $50-70 \mathrm{~V} / \mu \mathrm{g} / \mathrm{g}$ ). The zoom optics were set as follows: L1:22V; Lin1:250V; Lin2: $250 \mathrm{~V}$; all others zero. This provided a relative mass dispersion of 0.058 . Three blocks of 10 measurements of 5 seconds each were carried out for each sample, with a 10 second background measurement between each block measured at the half mass. The measurement was followed by 60 seconds wash time in two different wash solutions. This reduced memory effects to $<1 \mathrm{mV}$. 
The samples were bracketed with LSVEC reference material at the same concentration. Memory effects were negligible, rising from less than $100 \mathrm{cps}$ of ${ }^{7} \mathrm{Li}$ at the beginning of the measurement session to as much as $1 \mathrm{mV}$ after an entire day of measurement.

\subsubsection{SIMS}

[34] Samples were analyzed in both lithium concentration and isotope composition, using the single collector secondary ionization mass spectrometer Cameca ims 4f (ion microprobe) at the University of Edinburgh $(\mathrm{C}=71)$ following the method detailed by Kasemann et al. [2005]. Positive secondary ions of ${ }^{6} \mathrm{Li}^{+}$and ${ }^{7} \mathrm{Li}^{+}$were produced by a $20 \mathrm{nA}, 15 \mathrm{kV},{ }^{16} \mathrm{O}^{-}$primary beam focused to a $25 \mu \mathrm{m}$ spot size. The secondary ions were analyzed with an energy window of $52 \mathrm{eV}$, a $150 \mu \mathrm{m}$ image field using the $150 \mu \mathrm{m}$ contrast and the $1800 \mu \mathrm{m}$ field apertures and a mass resolution of $\sim 1400$. Secondary ions were counted on an electron multiplier in mono collector mode operation. To get an internal precision of $<1 \%$ ( $\left(1 \sigma_{\text {mean }}\right)$, the Li-isotope ratio was measured for 100 cycles, each cycle consisting of 5 and $2 \mathrm{~s}$ count times on ${ }^{6} \mathrm{Li}^{+}$and ${ }^{7} \mathrm{Li}^{+}$, respectively. Calibration to the international reference material was through BCR-2G $\left(\delta^{7} \mathrm{Li}=4.0 \pm 0.1 \%\right.$, $2 \sigma$ (MC-ICPMS); $4.0 \pm 0.6 \%$, $2 \sigma$ (TIMS) [Kasemann et al., 2005]) and additionally checked against GSD- $1 \mathrm{G}\left(\delta^{7} \mathrm{Li}=\right.$ $31.1 \pm 0.1 \%$, $2 \sigma$ (MC-ICPMS); $31.7 \pm 0.7 \%$, $2 \sigma$ (TIMS) [Kasemann et al., 2005]) showing an internal uncertainty of $0.8 \%$ o $\left(1 \sigma_{\text {mean }}\right)$ for a single point analysis and an external uncertainty of about $0.8 \%$ (1 SD). At least 10 lithium concentration and isotope measurements (with an average distance of 100-200 $\mu \mathrm{m}$ ) where done on two different glass fragments from each sample.

\subsubsection{Calcium Isotopes}

[35] The $\mathrm{Ca}$ isotopic compositions of the MPIDING glasses and the USGS reference materials BHVO-2 and BIR-1 were determined by thermal ionization mass spectrometry using a double spike technique at the IFM-GEOMAR, Kiel $(\mathrm{C}=80)$. After common $\mathrm{HF}-\mathrm{HNO}_{3}$ dissolution, the samples were subjected to a chromatographic clean up by elution with $1.8 \mathrm{~mol} \mathrm{l}^{-1} \mathrm{HCl}$ on cation-exchange columns (BioRad) filled with MCI Gel (75100 mesh; $0.6 \mathrm{ml}$ ). Fractionation effects on the column can be excluded since mixing the sample with an appropriate amount of spike before and after chemical separation resulted in the same isotope ratios within the error limits. Incidentally, $\mathrm{Ca}$ was eluted in a yield very close to $100 \%$.
Nonetheless the ${ }^{43} \mathrm{Ca}-{ }^{48} \mathrm{Ca}$ double spike was added to the sample in prior of chromatographic clean-up. After the chemical purification a total amount of about $300 \mathrm{ng} \mathrm{Ca}$ was then loaded with a $\mathrm{Ta}$ activator onto outgassed Re filaments. The measurements were carried out on a ThermoFinnigan Triton using the routine method of Heuser et al. [2002]. Mass fractionation was corrected by exponential law. A total procedure blank of less than $5 \mathrm{ng}$ was determined, so that blank corrections could be neglected. The $\mathrm{Ca}$ isotope data are denoted as $\delta$ values $\left({ }^{44 / 40} \mathrm{Ca}_{\text {sample }} /{ }^{44 / 40} \mathrm{Ca}_{\text {standard }}-1\right) \times$ 1000) [Eisenhauer et al., 2004] referred to IAPSO, which is with an average value of $1.86 \%$ relative to SRM 915a in accordance to the proposed values for seawater [Hippler et al., 2003].

\subsubsection{Strontium and Neodymium Isotopes}

[36] At the Max-Planck-Institut für Chemie Mainz $(\mathrm{C}=30){ }^{87} \mathrm{Sr} /{ }^{86} \mathrm{Sr}$ and ${ }^{143} \mathrm{Nd} /{ }^{144} \mathrm{Nd}$ isotope ratios of all MPI-DING glasses were determined by TIMS [Raczek et al., 2003]. The amount of samples used was 50-200 mg (aliquots of the $10 \mathrm{~g}$ glass powders [Jochum et al., 2000]) for each analysis. The samples were dissolved in Savillex beakers on a hot plate using $24 \mathrm{~mol}^{-1} \mathrm{HF}$ and $7 \mathrm{~mol}^{-1} \mathrm{HClO}_{4}$. The initial chemical separation of $\mathrm{Sr}$ and $\mathrm{Nd}$ followed standard ion exchange procedures, employing $5 \mathrm{ml}$ of AG50W-X12 (200-400 mesh) ion exchange resin. The REE fraction was further separated on a $2 \mathrm{ml}$ column of Teflon powder coated with di-2-ethylhexyl phosphoric acid. Neodymium was eluted with $0.18 \mathrm{~mol} \mathrm{l}^{-1} \mathrm{HCl}$. The isotope ratios were determined on a Finnigan MAT 261 mass spectrometer equipped with a multicollector of seven separate cups. Strontium (about $100 \mathrm{ng}$ ) was loaded with $\mathrm{TaF}_{5}$ on single $\mathrm{W}$ filaments, whereas $\mathrm{Nd}$ (100 ng, except BM90/21-G: $60 \mathrm{ng}$ ) was loaded on double Re filaments and analyzed as metal. During the analytical period, several measurements of NIST SRM $987 \mathrm{Sr}$ and La Jolla Nd reference samples gave the following values: ${ }^{87} \mathrm{Sr} /{ }^{86} \mathrm{Sr}=0.710203 \pm$ $0.000034(2 \mathrm{SD}),{ }^{143} \mathrm{Nd} /{ }^{144} \mathrm{Nd}=0.511839 \pm$ 0.000038 (2SD). Total procedural blanks were about $100 \mathrm{pg} \mathrm{Sr}$ and $10 \mathrm{pg} \mathrm{Nd}$.

\subsubsection{Hafnium Isotopes}

[37] Hafnium isotopes on KL2-G and ML3B-G were measured at the Max-Planck-Institut für Chemie Mainz, Germany $(\mathrm{C}=75)$. The chemical separation of Hf followed the procedure described in detail by Münker et al. [2001]. Hf isotope ratios were measured on a $\mathrm{Nu}$ Plasma multicollector 
ICPMS (MC-ICPMS) in static mode using a CETAC Aridus inlet system fitted with an ESI Teflon nebulizer with a $50 \mu \mathrm{l}$ flow rate. All isotope ratios were corrected with an exponential fractionation law using ${ }^{179} \mathrm{Hf} /{ }^{177} \mathrm{Hf}=0.7325$. Repeated measurements of the JMC $475 \mathrm{Hf}$ reference material averaged ${ }^{176} \mathrm{Hf} /{ }^{177} \mathrm{Hf}=$ $0.282161 \pm 0.000016(2 \mathrm{SD}, \mathrm{n}=361)$ over a period of about 2 years, resulting in an overall repeatability of the ${ }^{176} \mathrm{Hf} /{ }^{177} \mathrm{Hf}$ ratio of about $60 \mathrm{ppm}$. Procedural blank was $<250 \mathrm{pg}$. Repeated measurements of international reference materials (e.g., BHVO-1, BCR-1, BIR-1) show excellent reproducibility within 9-24 ppm to calculated average literature values [e.g., Blichert-Toft, 2001; Bizzarro et al., 2003].

\subsubsection{Lead Isotopes}

[38] Lead isotope ratios were determined by TIMS, MC-ICPMS, solution ICPMS and LA-ICPMS in the Mainz and Melbourne laboratories. The analytical data have been recently published by Jochum et al. [2005a, 2005b].

\subsubsection{TIMS}

[39] For the TIMS analyses at the Max-PlanckInstitut für Chemie $(C=29)$ the glass chips $(20-$ $140 \mathrm{mg}$ ) were repeatedly ultrasonicated in cold ultrapure water, and then washed in hot ultrapure water for $30 \mathrm{sec}$. After rinsing, the chips were dissolved in closed Savillex beakers using hot HFHNO3 (about 5: 1) for $>48$ hours. Lead separation was carried out on Bio-Rad AG1-X8 anion-exchange resin using a $\mathrm{HBr}-\mathrm{HNO}_{3}$ eluent. Measurements were done on a Finnigan MAT 261 mass spectrometer in static mode, applying the highly precise triple spike technique [Galer, 1999]. This technique requires the run of a spiked and unspiked sample aliquot to correct for instrumental mass fractionation, but improves the accuracy of the isotopic ratios significantly. Total procedural blanks were below $50 \mathrm{pg}$. In-run errors (2RSE) are of the order of $0.004-0.010 \%$ for ${ }^{206} \mathrm{~Pb} /{ }^{204} \mathrm{~Pb}$, ${ }^{207} \mathrm{~Pb} /{ }^{204} \mathrm{~Pb},{ }^{208} \mathrm{~Pb} /{ }^{204} \mathrm{~Pb}$ ratios, and $0.002-0.005 \%$ for ${ }^{207} \mathrm{~Pb} /{ }^{206} \mathrm{~Pb},{ }^{208} \mathrm{~Pb} /{ }^{206} \mathrm{~Pb}$ ratios.

\subsubsection{MC-ICPMS}

[40] $\mathrm{Pb}$ isotope compositions were determined by MC-ICPMS at the University of Melbourne $(\mathrm{C}=$ 64). The analytical procedures of the Melbourne laboratory are described in detail by Woodhead [2002]. Pb was separated from the samples by standard ion exchange procedures using BioRad AG1X-8 (200-400 mesh) resin and $\mathrm{HBr} / \mathrm{HCl}$.
Total procedural blanks were less than $20 \mathrm{pg}$. After chemical separation, samples were taken up in ca. $1 \mathrm{ml}$ of $10 \mathrm{ng} / \mathrm{g} \mathrm{Tl}$ solution in $2 \% \mathrm{HNO}_{3}$. Samples were introduced to a $\mathrm{Nu}$ Plasma MC-ICP mass spectrometer via a Cetac Aridus desolvating unit, using a Glass Expansion OpalMist nebulizer operating at an uptake rate of $\sim 30$ microliters $\mathrm{min}^{-1}$. All analyses were conducted in static mode using Faraday cups. Each analysis consisted of 4 blocks of data, each block comprising a $30 \mathrm{~s}$ baseline measurement and 20 scans of $10 \mathrm{~s}$ duration. Total $\mathrm{Pb}$ beams ranged from 5-10 V, typically consuming 30-60 ng of $\mathrm{Pb}$. Isotope ratios were corrected "on line" for $\mathrm{Hg}$ interference on ${ }^{204} \mathrm{~Pb}$. A modified Tl-normalization technique [Woodhead, 2002] was used to correct for mass bias. Within-run precision is typically in the order of $0.003 \%$ for ${ }^{206} \mathrm{~Pb} /{ }^{204} \mathrm{~Pb}$, ${ }^{207} \mathrm{~Pb} /{ }^{204} \mathrm{~Pb},{ }^{208} \mathrm{~Pb} /{ }^{204} \mathrm{~Pb}$ ratios.

\subsubsection{ICPMS}

[41] Between 50 and $150 \mathrm{mg}$ of glass chips were cleaned in purified water and then dissolved in an $\mathrm{HF}-\mathrm{HNO}_{3}$ mixture. After drying, the samples were treated twice with conc. $\mathrm{HCl}$ to eliminate fluorides before they were taken up in $0.4 \mathrm{~mol} \mathrm{l}^{-1} \mathrm{HNO}_{3}$. A thallium solution was added for mass fractionation. Procedural $\mathrm{Pb}$ blank was $30 \mathrm{pg}$. Pb isotopes were measured at the Max-Planck-Institut für Chemie Mainz $(\mathrm{C}=70)$ with a single-collector sector field ThermoFinnigan Element 2 ICP mass spectrometer equipped with a PFA microconcentric nebulizer and a PFA spray chamber. Ion intensities were measured by fast electric scanning in low mass resolution with flat top peaks. About 2100 scans have been performed for each measurement.

\subsubsection{LA-ICPMS}

[42] To demonstrate the capability of LA-ICPMS for in situ isotopic work, the MPI Mainz laboratory $(\mathrm{C}=72)$ has measured $\mathrm{Pb}$ isotopes in the MPIDING glasses using the New Wave UP-213 laser system and the ThermoFinnigan Element 2 ICP mass spectrometer (Table 4). Details are given by Jochum et al. [2005a, 2005b]. Three-spot analyses were done with spot diameters of 60-160 $\mu \mathrm{m}$. Ablation time was about $40 \mathrm{~s}$. To measure the $\mathrm{Pb}$ isotope ratios as precise as possible, the electrical scan mode of the mass spectrometer was used. Each run consisted of about 500 ablation measurements. Mass fractionation was determined from the deviation of the ${ }^{205} \mathrm{Tl}^{203} \mathrm{Tl}$ ratio in NIST SRM 612 measured prior to the MPI-DING glasses from the literature value of 2.3871 [Rosman and Taylor, 1998]. An in-run precision ( $1 \mathrm{RSE}$ ) for $\mathrm{Pb}>1 \mu \mathrm{g} / \mathrm{g}$ 


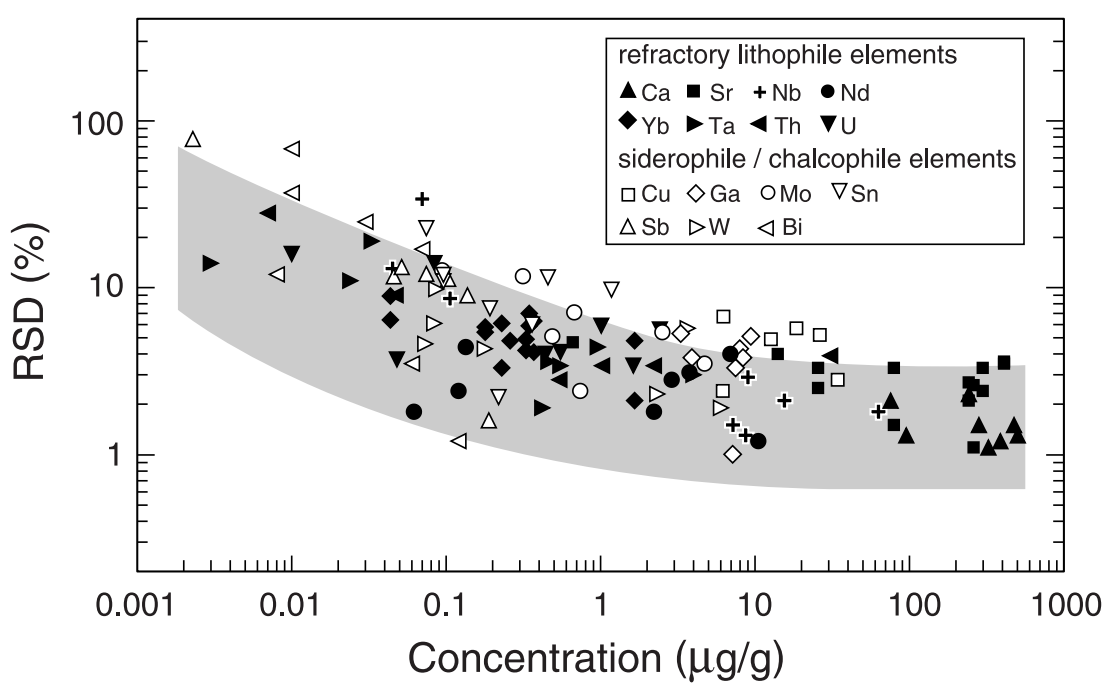

Figure 1. Concentrations and relative standard deviations (RSD) for elements of different geochemical behavior obtained from LA-ICPMS spot analyses on different locations of the MPI-DING reference glasses $(\mathrm{C}=47)$. Also shown is the repeatability field of LA-ICPMS. Most refractory lithophile and siderophile/chalcophile elements lie within this field, indicating that possible chemical heterogeneities are smaller than the combined standard uncertainty of LA-ICPMS, and hence are not detectable. Possible micro-heterogeneities $(<4 \%)$ are found for $\mathrm{Cu}, \mathrm{Sn}$, and $\mathrm{Bi}$.

of less than $0.1 \%$ was obtained. External precision is about $0.1-0.2 \%$.

\section{Analytical Results and Discussion}

\subsection{Homogeneity}

[43] Homogeneity is a fundamental requirement for any reference material. It is not an inherent property of the material, but is specific to both element and analytical test portion mass [Kane, 2002]. Therefore a reference glass could be homogeneous for most elements at bulk analytical tests and heterogeneous in most cases of microanalysis.

[44] The major and trace element homogeneity of the MPI-DING glasses was studied in detail by Jochum et al. [2000] using the microanalytical methods EPMA, SIMS, TOF-SIMS and SR-XRF. Analytical test portion masses for the different techniques range between $<1 \mathrm{ng}$ (EPMA) to about $3 \mu \mathrm{g}$ (LA-ICPMS).

[45] The major element homogeneity was evaluated by means of EPMA profiles. RSD variations (0.3$2 \%$ ) in all MPI-DING glasses except for the two komatiites GOR128-G and GOR132-G are similar to the ranges of analytical repeatability of EPMA analyses. This indicates that possible chemical heterogeneities are smaller than the analytical uncertainty and hence not detectable. Unequivocal mineralogical and chemical heterogeneities were observed in a few fragments of GOR128-G and GOR132-G, in which quench olivine crystals formed. However, these crystals are concentrated in small and limited areas, while most of the fragments are glassy throughout.

[46] Trace element investigations showed that RSD variations $(0.1-4 \%)$ of refractory lithophile elements (e.g., Sr, Ba, REE, Zr, Nb) were well within analytical errors. Heterogeneous distribution had been observed for Cr in ML3B-G (and may also exist in the other glasses) and for a few noble metals (due to variable loss to the platinum crucible during melting). New LA-ICPMS investigations $(\mathrm{C}=47)$ confirm the homogeneous distribution of many trace elements. This is shown in Figure 1 where the RSD values of trace elements are plotted versus their concentration. The data were obtained from 3-6 independent analyses performed on different splits of the reference glasses. The figure shows that the RSD values of refractory lithophile elements increase from about $1-3 \%$ at concentrations $>50 \mu \mathrm{g} / \mathrm{g}$ to about $5-20 \%$ at concentrations of $0.003-0.03 \mu \mathrm{g} / \mathrm{g}$. This RSD field reflects the repeatability of LA-ICPMS analyses $(\mathrm{C}=47)$ for homogeneous samples (K. P. Jochum et al., Trace element and isotope analyses of geo- and cosmochemical samples by laser ablation-sector fieldICPMS, submitted manuscript, 2005; hereinafter referred to as Jochum et al., submitted manuscript, 2005). Most siderophile and chalcophile elements are within this field indicating a similar homoge- 
neous distribution as the refractory lithophile elements. However, $\mathrm{Cu}, \mathrm{Sn}$ and $\mathrm{Bi}$ show larger variability (RSD of about 4\% for high concentrations). Inconsistent results for the noble metals Ir, Pt and $\mathrm{Au}$ have also been observed (auxiliary material ${ }^{1}$ Tables S1a-S1h). Heterogeneities of these and some other elements are also found in the NIST SRM 610-617 [Eggins and Shelley, 2002] and the USGS GS [Jochum et al., 2005c] glasses. They have been explained by loss of volatile components from the molten glass surface [Eggins and Shelley, 2002] and of siderophile elements to the platinum crucible [Rocholl et al., 1997] during preparation.

[47] Recently, Kempenaers et al. [2003] investigated possible micro-heterogeneity of StHs6/80-G, BM90/21-G, ML3B-G, KL2-G, ATHO-G and T1-G together with USGS BCR2-G and NIST SRM 613 in detail by measuring the elements K, $\mathrm{Ca}, \mathrm{Ti}, \mathrm{Cr}, \mathrm{Mn}, \mathrm{Fe}, \mathrm{Ni}, \mathrm{Cu}, \mathrm{Zn}, \mathrm{Ga}, \mathrm{Se}, \mathrm{Rb}, \mathrm{Sr}, \mathrm{Y}$, $\mathrm{Zr}, \mathrm{Nb}$ and $\mathrm{Mo}$. They used $\mu$ SR-XRF, a nondestructive trace-level microanalytical method with sufficiently low instrumental error. A procedure based on repeated analyses of the reference glass in many locations allowed the minimum sampling mass needed for a representative analysis to be calculated. For ML3B-G at least $5 \mathrm{ng}$ of material must be analyzed in order to obtain a materialrelated standard deviation below 5\%. This corresponds to a sample volume of $13 \times 13 \times 13 \mu^{3}$, i.e., somewhat smaller than what is typically vaporized during a LA-ICPMS pulse series or sampled during a $\mu$ SR-XRF experiment that makes use of a micro-beam of $10-15 \mu \mathrm{m}$ diameter. The results of StHs6/80, BM90/21-G, KL2-G, ATHO-G, T1-G were similar to that of ML3B-G. However, the minimal representative mass differed from element to element in the different glasses. Especially $\mathrm{Cu}$ in ATHO-G, T1-G and $\mathrm{Zn}$ in T1-G showed higher minimal representative mass values. At least $60 \mathrm{ng}$ of the material must be sampled/analyzed. When $\mathrm{Cu}$ and $\mathrm{Zn}$ are not considered, the minimal representative mass drops to about $20 \mathrm{ng}$ for all reference glasses. The authors conclude that the MPI-DING glasses appear to be well suited for calibration of trace-level micro analytical methods such as LA-ICP-MS, LIMS, $\mu$-PIXE and $\mu$-SR-XRF.

[48] In summary, many independent investigations showed that individual glass fragments of the MPIDING glasses are well homogenized with respect to both major and refractory lithophile trace elements at the $\mu \mathrm{m}$ to $\mathrm{mm}$ scale using $\mathrm{ng}-\mu \mathrm{g}$ analytical test portion masses, and this conclusion

\footnotetext{
${ }^{1}$ Auxiliary material is available at $\mathrm{ftp} / / / \mathrm{ftp}$.agu.org/apend/gc/ 2005GC001060.
}

appears to be true also for the entirety of the samples. Minimum test portion masses at which the samples appear homogeneous are about 5$20 \mathrm{ng}$. Micro-heterogeneities due to quench crystallization of olivine have been observed in small and limited areas of the komatiitic glasses GOR128-G and GOR132-G. Heterogeneities have also been observed for the trace elements $\mathrm{Cr}, \mathrm{Cu}$, $\mathrm{Zn}, \mathrm{Sn}, \mathrm{Bi}$ and for the noble metals Ir, Pt, $\mathrm{Au}$.

[49] To determine whether the MPI-DING glasses are also suitable geological reference materials for in situ isotope analysis, we have investigated possible small (within a single fragment) and large scale (different fragments) isotopic heterogeneities. Because of their low analytical uncertainty $(0.001-$ $0.1 \%$ ), large scale isotopic heterogeneities were tested by high-precision TIMS and MC-ICPMS (analytical test portion masses of about 20$100 \mathrm{mg}$ ). SIMS and LA-ICPMS (analytical test portion masses of about $5 \mathrm{ng}$ and $3 \mu \mathrm{g}$, respectively), where the analytical uncertainty is about $0.1-$ $0.3 \%$, were used to test for possible isotopic microheterogeneities of $\mathrm{Li}, \mathrm{B}$ and $\mathrm{Pb}$. The results of these investigations are discussed in detail for each isotope system in section 3.3.

\subsection{Element Abundances}

[50] Auxiliary material Tables S1a-S1i list the available major and trace element results for the MPIDING glasses. Most data are mean values of at least 5 individual analyses (see Tables 3 and 4). Besides of many new data, the tables contain already published concentration values (see Table 2). The data were obtained from more than 60 invited laboratories worldwide using 16 independent analytical methods. Estimated combined standard uncertainties [Eurachem, 2000], given as relative standard deviation in percent, the analytical technique used and the code (Table 2) are also given. Outliers are marked if the data are unacceptable presumably because of technical reasons. Most of the outliers have relatively high overall uncertainties (compared to other techniques) mainly caused by measurements near the detection limits or calibration errors. In the following, the results for the different elements and element groups, respectively, will be discussed in detail.

\subsubsection{Major and Minor Elements}

[51] Because of the limited sample size of the reference glasses the abundances of major and minor elements (expressed as oxide concentrations) are mainly determined by EPMA. This microanalytical technique is routinely used in geochemical 
laboratories and yields data with (estimated) uncertainties in the $1-4 \%$ (RSD) range depending on element and concentration levels. However, most EPMA results agree within 5-15\%, which is higher than the estimated combined standard uncertainties for the EPMA data. Because many investigations showed that the glass samples are well homogenized with respect to major and minor elements (with the exception of some small and limited crystal-bearing areas within the glass shards [Jochum et al., 2000] of the two komatiite glasses (see results for GOR128G; auxiliary material Table S1d, C = 32)) most discrepancies of the EPMA data may be caused by different correction procedures and calibration samples used. EPMA values are within the few results of bulk analytical techniques, such as XRF and INAA where large sample amounts $(0.1-0.8 \mathrm{~g})$ were used for an analysis. Major element data from other microanalytical techniques (LIMS, PIXE, SR-XRF) have higher uncertainties than the EPMA results. LAICPMS was used for the determination of some minor element concentrations (e.g., $\mathrm{TiO}_{2}, \mathrm{MnO}$ ) with good agreement with the EPMA data. A direct oxygen measurement by EPMA was given from the laboratory $\mathrm{C}=28$. Auxiliary material Tables S1aS1h contain $\mathrm{H}_{2} \mathrm{O}$ data for StHs6/80-G and T1-G using the method of Vennemann and O'Neil [1993]. $\mathrm{H}_{2} \mathrm{O}$ data obtained for all eight glasses by SIMS using the methods of Hauri et al. [2002] and Koga et al. [2003] give $\mathrm{H}_{2} \mathrm{O}$ data that are lower than the manometry data by a factor of $2-3$. It is thus possible that the manometry data contain additions from non-structural $\mathrm{H}_{2} \mathrm{O}$ trapped in micro-inclusions, or (less likely) incorporate water from $\mathrm{H}_{2} \mathrm{O}$-rich heterogeneities in the StHs6/80-G and T1-G glasses. $\mathrm{CO}_{2}$ data obtained by SIMS are at, or barely above, the detection limit. The combined $\mathrm{H}_{2} \mathrm{O}$ and $\mathrm{CO}_{2}$ data are consistent with air saturation at atmospheric pressure.

\subsection{2. $\mathrm{Li}, \mathrm{Be}, \mathrm{B}$}

[52] The database for these light trace elements has been improved compared to Jochum et al. [2000]. New data mainly come from LA-ICPMS, MCICPMS and SIMS laboratories. At the GeoForschungsZentrum Potsdam laboratory $(\mathrm{C}=33)$ boron concentrations of GOR128-G, GOR132-G and StHs6/80-G were determined using the wetchemical ICP-AES technique.

\subsubsection{F, $\mathrm{Cl}, \mathrm{Br}, \mathrm{S}$}

[53] Auxiliary material Tables S1a-S1h list new chlorine and sulfur data using EPMA, however, with large uncertainties. The $\mathrm{Cl}$ values are lower than the detection limits of INAA analyses previ- ously published. Fluorine, $\mathrm{Cl}$ and $\mathrm{S}$ data obtained by SIMS are all above the $0.5 \mu \mathrm{g} / \mathrm{g}$ detection limit with uncertainties ranging from $2 \%$ to $42 \%$ (2RSD); exceptions are $\mathrm{Cl}$ in BM90/21-G $(\sim 0.7 \mu \mathrm{g} / \mathrm{g})$ and $\mathrm{F}$ and $\mathrm{S}$ in ATHO-G $(\sim 0.7 \mu \mathrm{g} / \mathrm{g})$ which are only slightly above the detection limit. The slightly poorer level of reproducibility for $\mathrm{F}, \mathrm{Cl}$ and $\mathrm{S}$ for KL2-G and ML3-B compared to the others may be indicative of micron-scale heterogeneity in these elements. The reasons for the inconsistencies between the $\mathrm{Cl}$ data for ATHO-G are unclear. There are no new data for $\mathrm{Br}$.

\subsubsection{Sc, V, Cr, Co, Ni, Cu, Zn, Ga}

[54] LA-ICPMS has considerably expanded the database for these trace elements. New LA-ICPMS data for Sc are less precise than INAA values; however, most data agree within error limits. LA-ICPMS data for $\mathrm{Cr}, \mathrm{Co}, \mathrm{Ni}, \mathrm{Cu}, \mathrm{Zn}$ and $\mathrm{Ga}$ lie within the concentration ranges obtained from other analytical techniques. However, $\mathrm{Co}, \mathrm{Ni}, \mathrm{Cu}, \mathrm{Zn}, \mathrm{Ga}$ in some MPI-DING glasses vary widely presumably because of a more heterogeneous distribution of some siderophile and chalcophile trace elements in the glasses compared to refractory lithophile elements, such as $\mathrm{Sr}, \mathrm{Ba}, \mathrm{Yb}$ (see section 3.1).

\subsubsection{K, Rb, Cs}

[55] The preliminary reference values of Jochum et al. [2000] for K and Rb are well constrained because they are mainly based on high precise isotope dilution analyses using TIMS. New EPMA analyses have not changed significantly the accepted mean values for K. Many new ICP-MS and LA-ICPMS data are now available for $\mathrm{Rb}$ and $\mathrm{Cs}$.

\subsubsection{Ge, As, Se, Mo, Sn, Sb, Cd, In, W, Hg, Tl, Bi}

[56] The preliminary reference values for these elements [Jochum et al., 2000] are poorly constrained because of very few analyses. In most cases only information values, upper limits or even no values could be given. Auxiliary material Tables S1a-S1h show new data for these elements; however, in some cases they are inconsistent presumably because of analytical difficulties and possible heterogeneities in the MPI-DING glasses and/or the NIST glasses used for calibration.

\subsection{7. $\mathrm{Pb}$}

[57] The reliability of the $\mathrm{Pb}$ concentration has considerably improved by some new isotope dilution (ID) data using TIMS and ICPMS. New 
LA-ICPMS and ICPMS data are less precise; however, they agree with the results of other techniques.

\subsubsection{Sr, Ba, REE, Th, U}

[58] Partly more than 30 different results per reference glass are available for this group of elements which are of special interest in geochemistry. Analyses were performed by bulk (e.g., TIMS, INAA, SSMS, ICPMS) and microanalytical (e.g., SIMS, LA-ICPMS, SR-XRF) techniques in many laboratories. For most poly-isotopic elements ID data using TIMS, ICPMS, MC-ICPMS, SSMS and MIC-SSMS exist. Because isotope dilution is a definitive method considered to be free from bias [Heumann, 1988] requiring relatively large sample amounts (about $0.1 \mathrm{~g}$ ), these results are very precise, accurate and representative for the whole glass. The tables contain new data for $\mathrm{Sr}, \mathrm{Ba}, \mathrm{REE}$, Hf, U from a newly developed multielement IDICPMS method $(\mathrm{C}=35,48)$ which agree very well with the ID-TIMS $(\mathrm{C}=4)$, ID-SSMS $(\mathrm{C}=1)$ and ID-MIC-SSMS $(\mathrm{C}=2)$ data. Mean LA-ICPMS values also agree although the results of the different LA-ICPMS laboratories may differ up to $30 \%$. ID-TIMS $(C=53)$ was applied for Th and $U$ measurements of KL2-G and ML3B-G.

\subsubsection{Zr, Hf, Nb, Ta}

[59] Many analytical data exist for this element group. The concentrations of $\mathrm{Zr}$, Hf and Ta were precisely determined by isotope dilution using MC-ICPMS $(\mathrm{C}=26,74)$. New $\mathrm{Zr}$ and Hf IDICPMS data for KL2-G and ML3B-G $(\mathrm{C}=35,48)$ and data obtained by other techniques, mainly ICPMS and LA-ICPMS, expand the database for this element group.

\subsubsection{Noble Metals, Re}

[60] There are only few data for Re and the noble metals. Rhenium abundances in the MPI-DING glasses are very low and therefore difficult to determine. Noble metals differ extremely (up to a factor of 30 , e.g., Ir in T1-G). Besides analytical difficulties the major reason for these discrepancies may be a heterogeneous distribution of noble metals in the glass because of contamination by the Pt crucible during glass preparation [Dingwell et al., 1993].

\subsection{Isotope Data}

\subsubsection{Hydrogen Isotopes}

[61] The hydrogen isotope composition of the glasses $(\mathrm{C}=31)$ is expressed in the conventional $\delta$-notation relative to VSMOW in \%o (Table 5). The average precision of the isotopic measurement, on the basis of replicate analyses of standard reference material NBS-30 (biotite, $3.5 \% \mathrm{~m} / \mathrm{m}$ water, $\delta \mathrm{D}=$ $-65 \%$ ) is better than $\pm 2 \%(2 \sigma)$ and the accuracy is better than 5\%. As only single measurements were possible, given the analytical method used and the amount of material available, the homogeneity of the samples cannot be evaluated at the present time. The measured hydrogen isotope compositions of the glasses are marginally low in D-content compared to those for fresh magmatic glasses [e.g., Kyser, 1986; Taylor, 1986]. This may be a primary feature of the magmatic precursory material, relating to magmatic degassing during crystallization, or indicate hydrothermal alteration of the original sample material and/or exchange of hydrogen with ambient moisture during glass production. Alternatively, the much lower water contents determined by SIMS might mean that the manometry $\delta D$ values represent that of water trapped in microinclusions or heterogeneities in the StHs6/80-G and T1-G glasses.

\subsubsection{Oxygen Isotopes}

[62] The oxygen isotope compositions of all MPIDING glasses $(\mathrm{C}=31)$ are expressed in the standard $\delta$-notation, relative to VSMOW in \%o (Table 5). Replicate oxygen isotope analyses of different chips of the same sample and of the reference materials used (NIST SRM 8546 (NBS 28) quartz and UWG-2 garnet [Valley et al., 1995]) had an average reproducibility (2SD) of $\pm 0.07 \%$ for $\delta^{18} \mathrm{O}$ and $0.04 \%$ for $\delta^{17} \mathrm{O}$. The accuracy of both $\delta^{18} \mathrm{O}$ and $\delta^{17} \mathrm{O}$ values was better than $0.2 \%$ compared to accepted $\delta^{18} \mathrm{O}$ values for NIST SRM 8546 (NBS 28) of 9.64\% and UWG-2 of 5.8\% and an accepted $\delta^{17} \mathrm{O}$ value for NIST SRM 8546 (NBS 28) of $5.00 \%$. Hence the glasses have homogeneous isotope compositions on the scale of the measurements made here (equivalent to 1 to $3 \mathrm{mg}$ sample sizes). Compared to fresh peridotites, komatiites and basalts that commonly have $\delta^{18} \mathrm{O}$ values between 5 and $6 \%$, the glasses BM90/21-G, GOR128-G and GOR132-G, ML3B-G and KL2$\mathrm{G}$, respectively, all have unusually high $\delta^{18} \mathrm{O}$ values [Mattey et al., 1994; Harmon and Hoefs, 1995]. This may suggest oxygen isotope exchange between these ultramafic to mafic glasses and atmospheric oxygen (commonly $\delta^{18} \mathrm{O}=23 \%$ ) during the preparation of the glasses. Alternatively, the glasses were produced from rocks that have experienced low temperature hydrothermal alteration, a process that can readily lead to an increase 
Table 5. Hydrogen and Oxygen Isotope Compositions ${ }^{\mathrm{a}}$

\begin{tabular}{lccc}
\hline MPI-DING Glass & $\delta \mathrm{D}$ & $\delta^{17} \mathrm{O}$ & $\delta^{18} \mathrm{O}$ \\
\hline KL2-G & & $4.31 \pm 0.01$ & $8.63 \pm 0.09$ \\
ML3B-G & & $4.28 \pm 0.08$ & $8.35 \pm 0.22$ \\
StHs6/80-G & $-95 \pm 2$ & $3.21 \pm 0.10$ & $6.12 \pm 0.02$ \\
GOR128-G & & $4.83 \pm 0.00$ & $9.43 \pm 0.04$ \\
GOR132-G & & $4.34 \pm 0.00$ & $8.52 \pm 0.08$ \\
BM90/21-G & & $4.27 \pm 0.02$ & $8.40 \pm 0.01$ \\
T1-G & $-117 \pm 2$ & $3.89 \pm 0.01$ & $7.53 \pm 0.01$ \\
ATHO-G & & $1.59 \pm 0.02$ & $3.20 \pm 0.07$
\end{tabular}

${ }^{\mathrm{a}} \mathrm{C}=31$. Compositions are expressed in the standard $\delta$-notation, relative to VSMOW in permil. Precision $(2 \sigma)$ of the measurements is also indicated. Average reproducibility ( $2 \mathrm{SD}$, obtained from replicate analyses of reference materials) is about $2 \%(\delta \mathrm{D}), 0.04 \% 0\left(\delta^{17} \mathrm{O}\right)$, and $0.07 \%\left(\delta^{18} \mathrm{O}\right)$.

in ${ }^{18} \mathrm{O}$ compared to fresh magmatic rocks [e.g., Muehlenbachs, 1986]. The $\delta^{18} \mathrm{O}$ values of StHs6/ 80-G (andesite) and T1-G (quartz-diorite) have values that are more typical for fresh magmatic rocks of this type [e.g., Taylor and Sheppard, 1986]. In contrast, ATHO-G (rhyolite) has a $\delta^{18} \mathrm{O}$ value that is low compared to most fresh magmatic rocks of this type which may indicate hydrothermal alteration and isotopic exchange with low- $\delta^{18} \mathrm{O}$ meteoric waters of the rock prior to production of the glass and/or contamination of the magma with a low $\delta^{18} \mathrm{O}$-component during magma genesis [e.g., Taylor and Sheppard, 1986].

\subsubsection{Boron Isotopes}

[63] The boron isotope composition of GOR128-G, GOR132-G and StHs6/80-G (Table 6) was determined using TIMS $(\mathrm{C}=33)$ and LA-MC-ICPMS $(\mathrm{C}=76)$. The boron isotope data are listed as $\delta^{11} \mathrm{~B}$ values, i.e., normalized to the reference material NIST SRM 951.

[64] The in-run precision of the TIMS data is typically better than $0.15 \%$ o (2SE), whereas repeatability and reproducibility are up to one order of magnitude higher indicating the scatter between data from different TIMS measurements and/or independent chemical dissolution/separation aliquots. On the basis of these data and other recently published boron isotope data from the GeoForschungsZentrum Potsdam, the estimated combined standard uncertainty is better than $0.7 \%$ o (1 RSD; for detailed discussion, see Rosner and Meixner [2004]).

[65] The precision of the LA-MC-ICPMS data is significantly lower compared to the TIMS data. However, LA-MC-ICPMS has the advantages of minor sample preparation and high spatial resolution $(60-80 \mu \mathrm{m})$ [Tiepolo et al., 2005b]. As Figure 2 shows, $88 \%$ of the single spot analyses of GOR 128-G overlap the high-precision TIMS value [Rosner and Meixner, 2004] at the $1 \sigma$ level. All data for GOR128-G, GOR 132-G and StHs6/ 80-G [Tiepolo et al., 2005b] agree with the TIMS data at the $2 \sigma$ level indicating uniform distribution of $\mathrm{B}$ isotopes.

[66] The $\delta^{11} \mathrm{~B}$ value of $-4.48 \%$ o for StHs6/80-G is in the range of mantle derived rocks [e.g., Chaussidon and Marty, 1995]. The very high positive values of GOR128-G (13.55\%) and GOR132-G (7.11\%) indicate contamination of the mantle-derived magma, either by seawater altered crustal rocks during magma ascent or directly by assimilation of seawater $\left(\delta^{11} \mathrm{~B}=+39\right)$. Assuming an contaminant (seawater, seawater derived brine or seawater-altered crust) with a seawater like boron composition an increasing contamination would create a series of rocks with relatively low B contents coupled with low $\delta^{11} \mathrm{~B}$ values to relatively high $\mathrm{B}$ contents coupled with high $\delta^{11} \mathrm{~B}$ values. This is exactly displayed by the two komatiites. Moreover, the same systematic between a hypothetical seawater like contaminant and a mantle derived primary magma is shown by Li concentrations and $\delta^{7} \mathrm{Li}$ values of the GOR glasses.

Table 6. Boron Isotope Data Using TIMS $(\mathrm{C}=33)$ and LA-MC-ICPMS $(\mathrm{C}=76)^{\mathrm{a}}$

\begin{tabular}{|c|c|c|c|c|c|}
\hline \multirow[b]{2}{*}{ MPI-DING Glass } & \multicolumn{2}{|c|}{ TIMS } & \multicolumn{3}{|c|}{ LA-MC-ICPMS } \\
\hline & $\delta^{11} \mathrm{~B}, \%$ & $1 \mathrm{SD}, \%$ & $\delta^{11} \mathrm{~B}, \%$ & $1 \mathrm{SE}, \%$ & Remarks \\
\hline GOR128-G & 13.55 & 0.11 & 13.5 & 1.6 & $60 \mu \mathrm{m}$ spots \\
\hline & & & 14.5 & 2.8 & $80 \mu \mathrm{m}$ spots \\
\hline GOR132-G & 7.11 & 0.48 & 6.8 & 3.0 & $60 \mu \mathrm{m}$ spots \\
\hline StHs6/80-G & -4.48 & 0.14 & -4.3 & 2.4 & $80 \mu \mathrm{m}$ spots \\
\hline
\end{tabular}

\footnotetext{
${ }^{\mathrm{a}}$ TIMS, C = 33 [Rosner and Meixner, 2004]; LA-MC-ICPMS, C = 76 [Tiepolo et al., 2005b]. 1 SD values of TIMS data are based on 2-3 replicate measurements of the same homogeneous sample solution (GOR132-G, StHs6/80-G) and of two individual processed sample aliquots (GOR128-G), respectively. The 1 SE values of LA-MC-ICPMS data are based on 8 (GOR128-G) and 9 (GOR132-G, StHs6/80-G) replicates on the same glass sample. Data are expressed in the $\delta$-notation (see text) relative to NIST SRM951.
} 


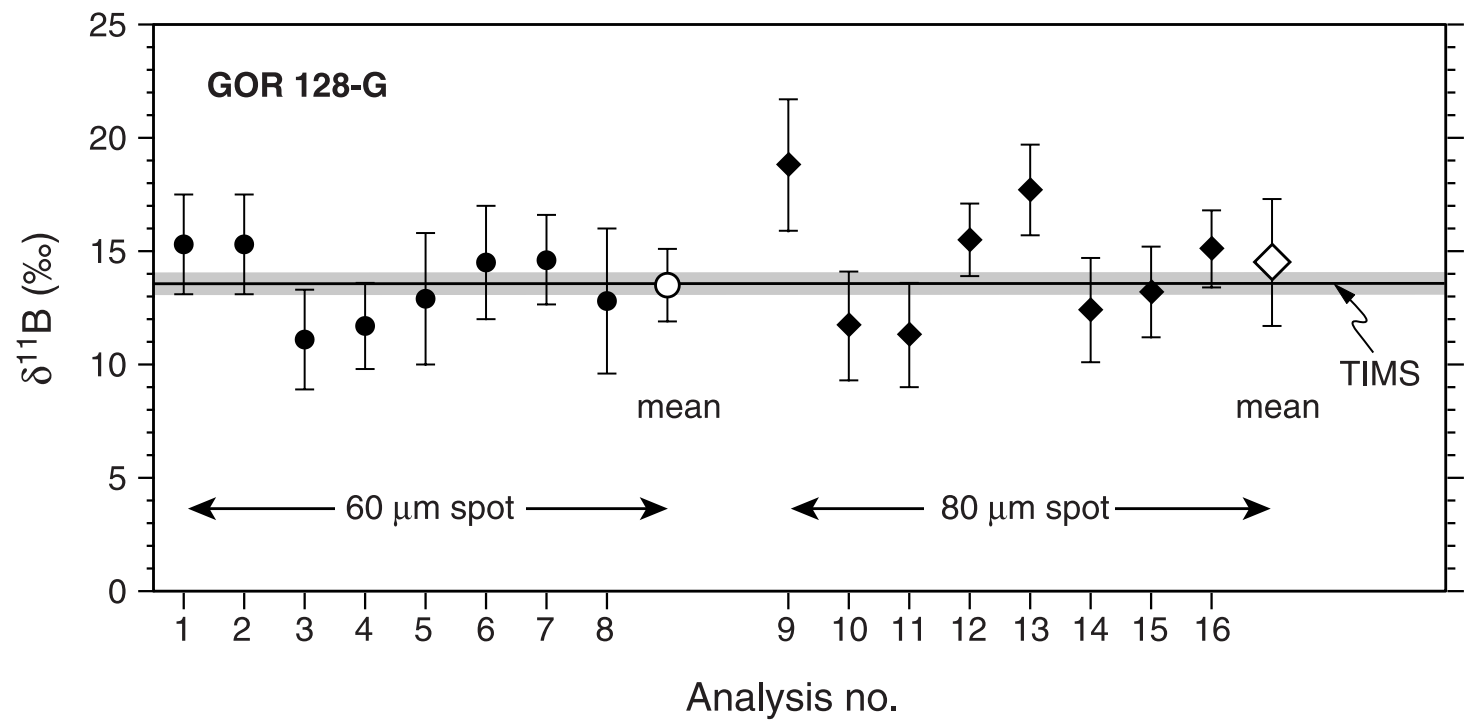

Figure 2. $\quad \delta^{11} \mathrm{~B}$ values for the komatiitic glass GOR 128-G obtained from LA-MC-ICPMS analyses using two different spot sizes. Nearly all single spot analyses overlap the high-precision TIMS value [Rosner and Meixner, 2004] at the $1 \sigma$ level.

However, the high boron concentrations of the GOR glasses require a relatively high boron concentration of the contaminant, which favors a seawater derived brine and/or highly altered crustal rocks and makes unmodified seawater an unlikely contaminant.

\subsubsection{Lithium Isotopes}

[67] The MC-ICPMS Li isotope data $(\mathrm{C}=82)$ are listed in Table 7. The reproducibility is dominated by residual errors in the standard bracketing technique. Repeat bracketed measurements of LSVEC give a total reproducibility for an individual analysis of 0.4 permil $(1 \sigma)$, similar to that achieved by other studies [cf. Jeffcoate et al., 2004]. BHVO-2 $(4.5 \%)$ and JG-2 $(-0.1 \% 0)$ analyses agree with published values [Jeffcoate et al., 2004], as do measurements of LSVEC that have been passed through the chemistry. For each dissolution a separate number is assigned, so that the variation between dissolutions of the same sample can be assessed. In some cases, measurements were performed both on the glass and on the sample powder the glass was made from. In the case of T1, no significant difference was found between glass and powder, in the case of BCR2 the difference is close to the analytical uncertainty, with the powder being slightly lighter than the glass. The USGS reference glasses BCR-2G (+5.0\%o) and GSD-1G (30.3\%o) are close to literature values [Kasemann et al., 2005]. The MPI-DING glasses range from $\delta^{7} \mathrm{Li}$ of 2.0 to $17.1 \%$. The uncertainties compared to the
Table 7. Lithium Isotope Data for MPI-DING Glasses and Other Reference Materials Using MC-ICPMS ${ }^{\mathrm{a}}$

\begin{tabular}{|c|c|c|c|}
\hline Reference Material & Diss. Number & Run Date & $\delta 7 \mathrm{Li}, \%$ \\
\hline GOR 132-G & H3 & 21.6 .05 & 8.9 \\
\hline GOR 128-G & H4 & 21.6 .05 & 14.4 \\
\hline \multirow[t]{2}{*}{ StHs6/80-G } & S5 & 30.5 .05 & 3.7 \\
\hline & & 30.5 .05 & 3.5 \\
\hline \multirow{2}{*}{$\mathrm{T} 1-\mathrm{G}$} & H8 & 17.6 .05 & 2.1 \\
\hline & & 17.6 .05 & 2.0 \\
\hline \multirow[t]{2}{*}{ ATHO-G } & S7 & 30.5 .05 & 17.1 \\
\hline & & 30.5 .05 & 17.1 \\
\hline \multirow[t]{2}{*}{ ML3B-G } & H1 & 17.6 .05 & 4.3 \\
\hline & & 17.6 .05 & 4.4 \\
\hline $\begin{array}{l}\text { L-SVEC } \\
\quad \text { (NIST SRM 8545) }\end{array}$ & A3 & 30.5 .05 & -0.1 \\
\hline through column & & 30.5 .05 & 0.0 \\
\hline \multirow[t]{2}{*}{ BCR-2G } & H6 & 17.6 .05 & 5.0 \\
\hline & & 17.6 .05 & 5.0 \\
\hline \multirow[t]{2}{*}{ GSD-1G } & S9 & 30.5 .05 & 30.4 \\
\hline & & 30.5 .05 & 30.2 \\
\hline \multirow[t]{2}{*}{ T1 (powder) } & H9 & 17.6 .05 & 2.6 \\
\hline & & 17.6.05 & 2.6 \\
\hline \multirow[t]{2}{*}{ BCR-2 (powder) } & H7 & 17.6 .05 & 4.6 \\
\hline & & 17.6 .05 & 4.2 \\
\hline \multirow[t]{3}{*}{ BHVO-2 (powder) } & A1 & 30.5 .05 & 4.4 \\
\hline & & 30.5 .05 & 4.1 \\
\hline & & 30.5 .05 & 4.2 \\
\hline \multirow[t]{2}{*}{ BHVO-2 (powder) } & H5 & 17.6 .05 & 4.9 \\
\hline & & 17.6 .05 & 4.7 \\
\hline \multirow[t]{3}{*}{ JG-2 (powder) } & $\mathrm{A} 2$ & 30.5 .05 & 0.1 \\
\hline & & 30.5 .05 & -0.1 \\
\hline & & 30.5 .05 & -0.1 \\
\hline
\end{tabular}

${ }^{\mathrm{a}} \mathrm{C}=82$. Data are relative to LVSEC (NIST SRM 8545). Data are also given for $\mathrm{T} 1$, the original rock powder of T1-G. Uncertainty ( $1 \mathrm{SD})$ is $\pm 0.4 \%$ based on repeated measurements. Dissolution numbers are given to provide controls on variability between aliquots. 
Table 8. Lithium Isotope Data for 5 MPI-DING and 2 USGS Reference Glasses Using SIMS

\begin{tabular}{|c|c|c|c|c|c|}
\hline \multirow[b]{2}{*}{ MPI-DING KL2-G } & \multicolumn{2}{|c|}{$\delta^{7} \mathrm{Li}, \%$} & \multirow[b]{2}{*}{ MPI-DING GOR128-G } & \multicolumn{2}{|c|}{$\delta^{7} \mathrm{Li}, \%$} \\
\hline & Split 1 & Split 2 & & Split 1 & Split 2 \\
\hline Analysis $1( \pm \mathrm{SE})$ & $4.8 \pm 0.9$ & $3.8 \pm 1.1$ & Analysis $1( \pm \mathrm{SE})$ & $12.0 \pm 1.0$ & $10.2 \pm 0.6$ \\
\hline Analysis $2( \pm \mathrm{SE})$ & $3.2 \pm 1.0$ & $5.9 \pm 1.0$ & Analysis $2( \pm \mathrm{SE})$ & $12.2 \pm 0.7$ & $13.1 \pm 0.8$ \\
\hline Analysis $3( \pm \mathrm{SE})$ & $6.3 \pm 0.8$ & $1.7 \pm 1.0$ & Analysis $3( \pm \mathrm{SE})$ & $13.1 \pm 0.7$ & $14.1 \pm 0.7$ \\
\hline Analysis $4( \pm$ SE) & $3.9 \pm 1.0$ & $4.8 \pm 0.9$ & Analysis $4( \pm \mathrm{SE})$ & $12.8 \pm 0.8$ & $13.1 \pm 0.9$ \\
\hline Analysis $5( \pm$ SE) & $3.8 \pm 1.0$ & $2.3 \pm 1.1$ & Analysis $5( \pm \mathrm{SE})$ & $12.4 \pm 0.9$ & $12.6 \pm 0.8$ \\
\hline Mean $( \pm \mathrm{SD})$ & $4.4 \pm 1.2$ & $3.7 \pm 1.8$ & Mean $( \pm$ SD $)$ & $12.5 \pm 0.4$ & $12.6 \pm 1.4$ \\
\hline Total mean $( \pm$ SD $)$ & \multicolumn{2}{|c|}{$4.1 \pm 1.5$} & Total mean $( \pm$ SD) & \multicolumn{2}{|c|}{$12.6 \pm 1.0$} \\
\hline MPI-DING ML3B-G & Split 1 & Split 2 & MPI-DING GOR132-G & Split 1 & Split 2 \\
\hline Analysis $1( \pm \mathrm{SE})$ & $3.6 \pm 1.1$ & $3.4 \pm 0.9$ & Analysis $1( \pm \mathrm{SE})$ & $8.4 \pm 0.8$ & $7.9 \pm 1.0$ \\
\hline Analysis $2( \pm \mathrm{SE})$ & $5.2 \pm 1.4$ & $3.4 \pm 1.1$ & Analysis $2( \pm \mathrm{SE})$ & $8.8 \pm 0.8$ & $8.1 \pm 1.0$ \\
\hline Analysis $3( \pm \mathrm{SE})$ & $3.8 \pm 1.2$ & $3.9 \pm 1.2$ & Analysis $3( \pm \mathrm{SE})$ & $9.6 \pm 1.0$ & $7.6 \pm 1.0$ \\
\hline Analysis $4( \pm \mathrm{SE})$ & $3.6 \pm 1.0$ & $6.7 \pm 1.3$ & Analysis $4( \pm \mathrm{SE})$ & $9.6 \pm 0.9$ & $8.5 \pm 0.9$ \\
\hline Analysis $5( \pm \mathrm{SE})$ & $5.0 \pm 1.3$ & $7.4 \pm 1.1$ & Analysis $5( \pm \mathrm{SE})$ & $8.3 \pm 1.0$ & $9.6 \pm 0.9$ \\
\hline Analysis $6( \pm \mathrm{SE})$ & \multirow[t]{3}{*}{$3.0 \pm 1.2$} & $7.2 \pm 1.1$ & Analysis $6( \pm \mathrm{SE})$ & $8.8 \pm 0.8$ & \multirow[t]{3}{*}{$8.5 \pm 0.8$} \\
\hline Analysis $7( \pm \mathrm{SE})$ & & $4.6 \pm 1.2$ & Analysis $7( \pm \mathrm{SE})$ & $8.4 \pm 0.9$ & \\
\hline Analysis $8( \pm \mathrm{SE})$ & & $5.4 \pm 1.1$ & & & \\
\hline Mean $( \pm \mathrm{SD})$ & $4.0 \pm 0.9$ & $5.2 \pm 1.7$ & Mean $( \pm \mathrm{SD})$ & $8.8 \pm 0.6$ & $8.4 \pm 0.7$ \\
\hline Total mean $( \pm$ SD) & \multicolumn{2}{|c|}{$4.7 \pm 1.5$} & Total mean $( \pm \mathrm{SD})$ & \multicolumn{2}{|c|}{$8.6 \pm 0.6$} \\
\hline MPI-DING T1-G & split 1 & split 2 & USGS & GSD-1G & BCR-2G \\
\hline Analysis $1( \pm \mathrm{SE})$ & $0.5 \pm 0.6$ & $-0.3 \pm 0.5$ & Analysis $1( \pm \mathrm{SE})$ & $31.2 \pm 0.6$ & $3.7 \pm 0.9$ \\
\hline Analysis $2( \pm \mathrm{SE})$ & $-1.2 \pm 0.6$ & $-0.2 \pm 0.4$ & Analysis $2( \pm \mathrm{SE})$ & $30.3 \pm 0.5$ & $4.4 \pm 1.0$ \\
\hline Analysis $3( \pm \mathrm{SE})$ & $-1.6 \pm 0.6$ & $0.8 \pm 0.4$ & Analysis $3( \pm \mathrm{SE})$ & $32.1 \pm 0.5$ & $4.7 \pm 1.0$ \\
\hline Analysis $4( \pm \mathrm{SE})$ & $-0.3 \pm 0.6$ & $0.0 \pm 0.6$ & Analysis $4( \pm \mathrm{SE})$ & $31.4 \pm 0.4$ & $4.6 \pm 0.8$ \\
\hline Analysis $5( \pm \mathrm{SE})$ & $0.4 \pm 0.6$ & $-0.1 \pm 0.5$ & Analysis $5( \pm \mathrm{SE})$ & $31.8 \pm 0.4$ & $2.9 \pm 1.0$ \\
\hline \multirow[t]{4}{*}{ Analysis $6( \pm \mathrm{SE})$} & $0.7 \pm 0.5$ & $0.1 \pm 0.6$ & Analysis $6( \pm \mathrm{SE})$ & $30.7 \pm 0.4$ & $3.0 \pm 1.3$ \\
\hline & & & Analysis $7( \pm \mathrm{SE})$ & $31.0 \pm 0.4$ & $4.2 \pm 0.6$ \\
\hline & & & Analysis $8( \pm \mathrm{SE})$ & $31.5 \pm 0.4$ & $4.4 \pm 0.8$ \\
\hline & & & Analysis $9( \pm \mathrm{SE})$ & & $4.1 \pm 0.6$ \\
\hline Mean $( \pm$ SD) & $-0.3 \pm 1.0$ & $0.0 \pm 0.4$ & Analysis $10( \pm \mathrm{SE})$ & & $5.4 \pm 0.8$ \\
\hline \multirow[t]{6}{*}{ Total mean $( \pm$ SD) } & \multirow{6}{*}{\multicolumn{2}{|c|}{$-0.1 \pm 0.7$}} & Analysis $11( \pm \mathrm{SE})$ & & $3.4 \pm 0.8$ \\
\hline & & & Analysis $12( \pm \mathrm{SE})$ & & $4.1 \pm 0.7$ \\
\hline & & & Analysis $13( \pm \mathrm{SE})$ & & $3.6 \pm 1.0$ \\
\hline & & & Analysis $14( \pm \mathrm{SE})$ & & $5.2 \pm 0.8$ \\
\hline & & & Analysis $15( \pm \mathrm{SE})$ & & $3.4 \pm 0.9$ \\
\hline & & & Mean ( \pm SD) & $31.3 \pm 0.6$ & $4.1 \pm 0.8$ \\
\hline
\end{tabular}

${ }^{\mathrm{a}} \mathrm{C}=71$. Data are given relative to the reference material LSVEC (NIST SRM 8545). Distances between different analyses were about $100 \mu \mathrm{m}$. Uncertainty on a single analysis is $1 \mathrm{SE}$ obtained from 100 analytical cycles.

SIMS data (Table 8) are smaller, owing to the larger amount of Li measured. The data are within the range of the SIMS data except for the sample $\mathrm{T} 1-\mathrm{G}$, which is about $2 \%$ heavier.

[68] Table 8 lists $\mathrm{Li}$ isotope data obtained from SIMS measurements $(C=71)$. Two different splits were analyzed at 5-8 points. Distances between the points were about $100 \mu \mathrm{m} . \delta^{7} \mathrm{Li}$ values of the MPI-DING glasses differ significantly with the exception of the Hawaiian basalt glasses KL2-G and ML3B-G. Some local heterogeneity in $\mathrm{Li}$ isotopes could be observed (Figure 3). ML3B-G shows higher $\delta^{7} \mathrm{Li}$ values in an area of about $200 \mu \mathrm{m}$. All $\delta^{7} \mathrm{Li}$ values for GOR128-G agree with the exception of the result of one point where $\delta^{7} \mathrm{Li}$ is $20 \%$ lower.

\subsubsection{Calcium Isotopes}

[69] The TIMS data of the Ca isotopes are listed in Table $9(\mathrm{C}=80)$. They are averages of at least four duplicate analyses including separate column chemistry and replicated measurements. Two standard deviations of the mean are less than $0.2 \%$. At first glance, the data matches with those from the few data available in literature (see compilation by DePaolo [2004]). However, a general convention is needed for the $\mathrm{Ca}$ isotope composition in igneous rocks such as an international rock reference 


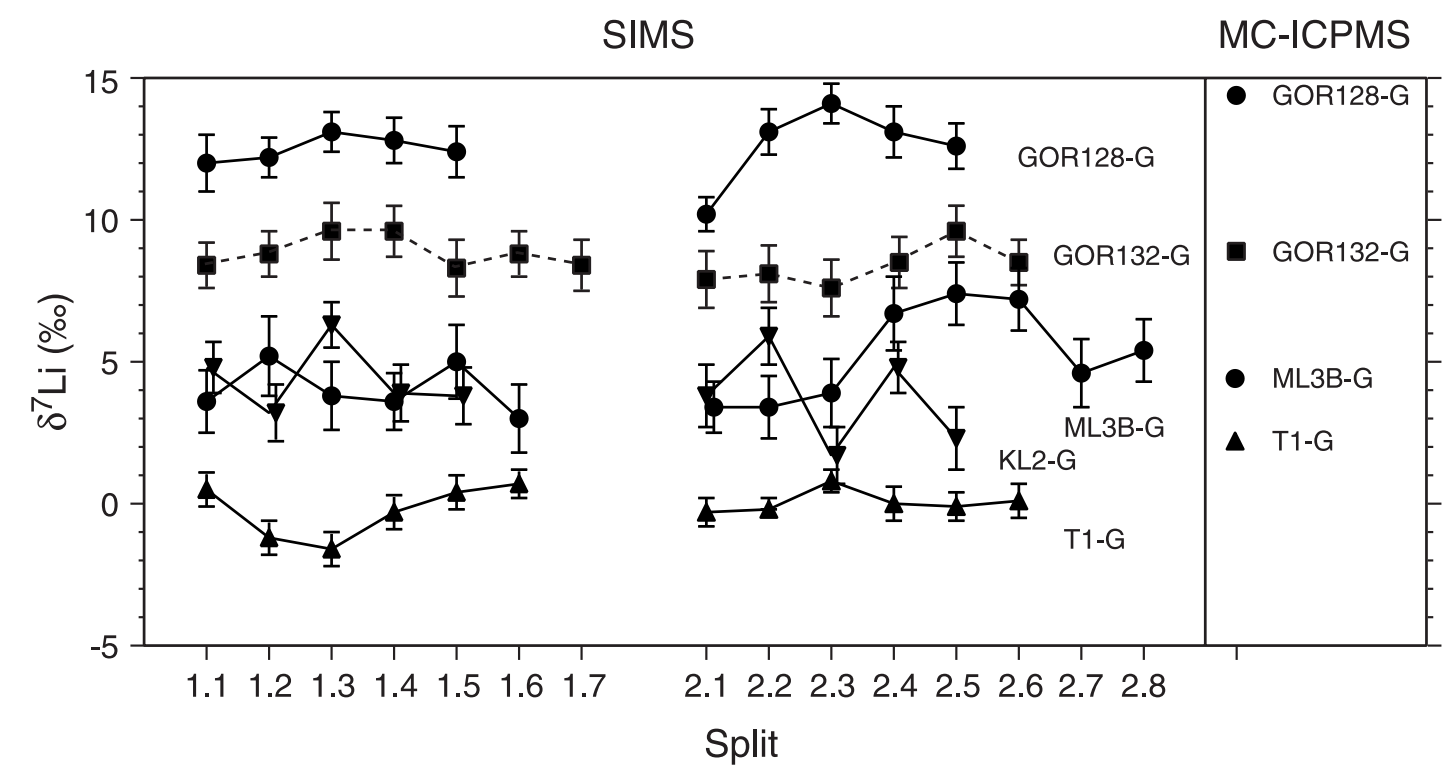

Figure 3. $\delta^{7} \mathrm{Li}$ values for five MPI-DING glasses. Two different splits were analyzed at $5-8$ points by SIMS $(\mathrm{C}=$ 71). Distances between the points were about $100 \mu \mathrm{m}$. Bars indicate \pm 1 SD. Slight micro-heterogeneities of Li isotopes could be observed for GOR 128-G and ML3B-G. The figure also contains the MC-ICPMS data $(\mathrm{C}=82)$ for four of these glasses.

material. The values of Table 9 are normalized to NIST SRM 915a, which is generally used as standard reference material for carbonates, and to IAPSO, which is a salinity (seawater) reference material.

\subsubsection{Strontium and Neodymium Isotopes}

[70] Up to three ${ }^{87} \mathrm{Sr} /{ }^{86} \mathrm{Sr}$ and ${ }^{143} \mathrm{Nd} /{ }^{144} \mathrm{Nd}$ isotope analyses were performed for each glass (Table 10) using TIMS $(\mathrm{C}=30)$. The data for replicate analyses agree within uncertainty limits (repeatability, 2SD $=0.000034$ for ${ }^{87} \mathrm{Sr} /{ }^{86} \mathrm{Sr}, 0.000038$ for ${ }^{143} \mathrm{Nd} /{ }^{144} \mathrm{Nd}$ ). Strontium and $\mathrm{Nd}$ isotopes were previously determined in the original rock powders of KL-2 and ML3-B [Newsom et al., 1986], which were used for the preparation of the reference glasses KL2-G and ML3B-G, respectively. The $\mathrm{Sr}$ data for the glasses and the powders (KL-2: 0.703497; ML-3B: 0.703817) agree within confidence intervals, whereas the $\mathrm{Nd}$ ratios of the original powders (KL-2: 0.512985; ML-3B: 0.512889 ) are slightly higher compared to those of the reference glasses, presumably because of larger uncertainties of the old data.

\subsubsection{Hafnium Isotopes}

[71] The Hf isotopic composition of two glasses is listed in Table 11. Replicate MC-ICPMS analyses $(\mathrm{C}=75)$ are identical within confidence intervals. The data for KL2-G and ML3B-G, two basalts from

Table 9. Calcium Isotope TIMS Data for the MPI-DING Glasses, the Salinity Standard IAPSO, and the USGS Reference Materials BHVO-2 and BIR-1 ${ }^{\text {a }}$

\begin{tabular}{lccc}
\hline Reference Materials & $\delta^{44 / 40} \mathrm{Ca}(\%$ IAPSO) & $\delta^{44 / 40} \mathrm{Ca}\left(\%{ }_{0}\right.$ NISTSRM915a) & $2 \sigma_{\text {mean }}$ \\
\hline KL2-G & -1.18 & 0.67 & $0.09(\mathrm{n}=10)$ \\
ML3B-G & -1.18 & 0.67 & $0.09(\mathrm{n}=13)$ \\
T1-G & -1.13 & 0.73 & $0.13(\mathrm{n}=9)$ \\
StHs6/80-G & -1.12 & 0.74 & $0.08(\mathrm{n}=9)$ \\
GOR 128-G & -1.19 & 0.66 & $0.04(\mathrm{n}=5)$ \\
GOR 132-G & -1.36 & 0.49 & $0.11(\mathrm{n}=6)$ \\
ATHO-G & -1.02 & 0.84 & $0.20(\mathrm{n}=4)$ \\
BM90/21-G & -0.56 & 1.29 & $0.15(\mathrm{n}=7)$ \\
IAPSO & & 1.85 & $0.04(\mathrm{n}=47)$ \\
BHVO-2 & -1.18 & 0.67 & $0.08(\mathrm{n}=13)$ \\
BIR-1 & -1.05 & 0.80 & $0.05(\mathrm{n}=11)$
\end{tabular}

${ }^{a} \mathrm{C}=80$. The long-term precision is about $0.15 \%$ (2SD). 
Table 10. Sr and Nd Isotopic Ratios of MPI-DING Reference Glasses ${ }^{\mathrm{a}}$

\begin{tabular}{|c|c|c|c|c|c|}
\hline MPI-DING Glass & ${ }^{87} \mathrm{Sr} /{ }^{86} \mathrm{Sr}$ & ${ }^{143} \mathrm{Nd} /{ }^{144} \mathrm{Nd}$ & MPI-DING Glass & ${ }^{87} \mathrm{Sr} /{ }^{86} \mathrm{Sr}$ & ${ }^{143} \mathrm{Nd} /{ }^{144} \mathrm{Nd}$ \\
\hline KL2-G & $0.703517 \pm 9$ & $\begin{array}{l}0.512953 \pm 9 \\
0.512946 \pm 5\end{array}$ & GOR132-G & $\begin{array}{l}0.707165 \pm 7 \\
0.707147 \pm 9\end{array}$ & $0.513282 \pm 8$ \\
\hline KL2-G (mean) & 0.703517 & 0.512950 & GOR132-G (mean) & 0.707156 & 0.513282 \\
\hline ML3B-G & $\begin{array}{l}0.703796 \pm 10 \\
0.703809 \pm 12 \\
0.703809 \pm 10\end{array}$ & $\begin{array}{l}0.512878 \pm 8 \\
0.512871 \pm 6\end{array}$ & BM90/21-G & $\begin{array}{l}0.706268 \pm 16 \\
0.706284 \pm 13\end{array}$ & $0.512598 \pm 10$ \\
\hline ML3B-G (mean) & 0.703805 & 0.512875 & BM90/21-G (mean) & 0.706276 & 0.512598 \\
\hline StHs6/80-G & $\begin{array}{l}0.703500 \pm 8 \\
0.703494 \pm 7\end{array}$ & $\begin{array}{l}0.512898 \pm 6 \\
0.512890 \pm 8\end{array}$ & $\mathrm{~T} 1-\mathrm{G}$ & $\begin{array}{l}0.710094 \pm 7 \\
0.710091 \pm 9\end{array}$ & $\begin{array}{l}0.512332 \pm 6 \\
0.512320 \pm 6\end{array}$ \\
\hline StHs6/80-G (mean) & 0.703497 & 0.512894 & T1-G (mean) & 0.710093 & 0.512326 \\
\hline GOR128-G & $\begin{array}{l}0.706877 \pm 9 \\
0.706898 \pm 9\end{array}$ & $\begin{array}{l}0.513240 \pm 6 \\
0.513228 \pm 7\end{array}$ & ATHO-G & $0.703224 \pm 9$ & $\begin{array}{c}0.513006 \pm 10 \\
0.513011 \pm 8\end{array}$ \\
\hline GOR128-G (mean) & 0.706888 & 0.513234 & ATHO-G (mean) & 0.703224 & 0.513009 \\
\hline
\end{tabular}

Kilauea and Mauna Loa, Hawaii, respectively, are within the range of those reported from other Hawaiian samples [e.g., Blichert-Toft et al., 1999].

\subsubsection{Lead Isotopes}

[72] Lead isotope ratios have been determined by TIMS $(\mathrm{C}=29)$, MC-ICPMS $(\mathrm{C}=64)$, LA-ICPMS $(\mathrm{C}=72)$ and solution ICPMS $(\mathrm{C}=70)$. The results of these investigations have been recently published by Jochum et al. [2005b]. Table 12 shows the average isotope ratios obtained for the different reference glasses. ${ }^{208} \mathrm{~Pb} /{ }^{206} \mathrm{~Pb}$ and ${ }^{207} \mathrm{~Pb} /{ }^{206} \mathrm{~Pb}$ ratios, which are commonly utilized for in situ $\mathrm{Pb}$ isotope studies, vary from 2.010 (GOR132-G) to 2.081 (T1-G) and 0.8164 (GOR132-G) to 0.8438 (GOR 128-G), respectively.

[73] Possible heterogeneities of $\mathrm{Pb}$ isotopes are found for ML3B-G and KL2-G by high-precision triple spike TIMS and MC-ICPMS measurements using different glass chips (sample amount 20$140 \mathrm{mg}$ ). As Figure 4 shows, small but significant differences could be found for ${ }^{208} \mathrm{~Pb} /{ }^{206} \mathrm{~Pb}$ in the different glass fragments, especially for sample ML3B-G. A reason for the discrepancies may be sample heterogeneities superimposed to the samples during glass preparation. However, the differences are small (about $0.02-0.05 \%$ ) and lower than the reproducibility $(0.1-0.3 \%)$ obtained from microanalytical techniques, such as LA-ICPMS and SIMS.

\section{Geochemical Characterization}

[74] Jochum et al. [2000] prepared eight MPIDING glasses for in situ microanalytical work which should fit the International Organisation for Standardization (ISO) definition of reference materials (ISO Guide 30 [ISO, 1992]), namely a sufficiently homogeneous material to be used for the calibration of an apparatus, the assessment of a measurement method, or for assigning values to materials. They followed the recommendations for the certification of reference materials of Kane and Potts [1997, 1999] and published preliminary reference values and information values.

[75] Recently, the IAG undertook efforts to function as a certifying body and to develop a protocol for the certification of geological and environmental reference materials to comply to the fullest extent possi-

Table 11. Hf Isotope Data

\begin{tabular}{ccc}
\hline MPI-DING Glass & ${ }^{176} \mathrm{Hf} /{ }^{177} \mathrm{Hf}$ & Analysis Period \\
\hline KL2-G & $0.283114 \pm 0.000010$ & January 2004 \\
& $0.283106 \pm 0.000004$ & November 2004 \\
& $0.283107 \pm 0.000005$ & January 2005 \\
mean \\
ML3B-G & $0.283067 \pm 0.000005$ & November 2004 \\
& $0.283067 \pm 0.000009$ & January 2005 \\
& $\mathbf{0 . 2 8 3 0 6 7}$ & mean \\
BCR-1 & $0.282864 \pm 0.000009$ & January 2004 \\
& $0.282860 \pm 0.000006$ & January 2004 \\
& $0.282874 \pm 0.000004$ & November 2004 \\
& $0.282877 \pm 0.000005$ & January 2005 \\
BHVO-1 & $\mathbf{0 . 2 8 2 8 6 9}$ & mean \\
& $0.283105 \pm 0.000006$ & January 2004 \\
& $0.283106 \pm 0.000008$ & November 2004 \\
& $0.283101 \pm 0.000008$ & January 2005 \\
& $\mathbf{0 . 2 8 3 1 0 4}$ & mean \\
BIR-1 & $0.283276 \pm 0.000005$ & November 2004 \\
& $0.283270 \pm 0.000010$ & November 2004 \\
& $\mathbf{0 . 2 8 3 2 7 3}$ & mean \\
\hline
\end{tabular}

${ }^{\mathrm{a}} \mathrm{C}=75$. Uncertainties represent in-run precision (2 SE). External precision $(2 \mathrm{SD})$ is 0.000017 . 
Table 12. Pb Isotope Data for the MPI-DING Glasses ${ }^{\mathrm{a}}$

\begin{tabular}{|c|c|c|c|c|c|c|}
\hline Reference Material & $\mathrm{N}$ & ${ }^{206} \mathrm{~Pb} /{ }^{204} \mathrm{~Pb}$ & ${ }^{207} \mathrm{~Pb} /{ }^{204} \mathrm{~Pb}$ & ${ }^{208} \mathrm{~Pb} /{ }^{204} \mathrm{~Pb}$ & ${ }^{208} \mathrm{~Pb} /{ }^{206} \mathrm{~Pb}$ & ${ }^{207} \mathrm{~Pb} /{ }^{206} \mathrm{~Pb}$ \\
\hline \multicolumn{7}{|c|}{$T I M S^{b}$} \\
\hline KL2-G & 4 & 19.031 & 15.634 & 38.528 & 2.0245 & 0.82149 \\
\hline ML3B-G & 2 & 18.730 & 15.607 & 38.477 & 2.0543 & 0.83326 \\
\hline ATHO-G & 1 & 18.387 & 15.481 & 38.115 & 2.0729 & 0.84196 \\
\hline StHs6/80-G & 1 & 18.900 & 15.614 & 38.515 & 2.0378 & 0.82611 \\
\hline $\mathrm{T} 1-\mathrm{G}$ & 1 & 18.726 & 15.679 & 38.974 & 2.0813 & 0.83726 \\
\hline NIST SRM 981 & & 16.942 & 15.499 & 36.731 & 2.1680 & 0.91485 \\
\hline \multicolumn{7}{|c|}{$M C-I C P M S^{\mathrm{c}}$} \\
\hline KL2-G & 1 & 19.026 & 15.628 & 38.507 & 2.0239 & 0.82141 \\
\hline ML3B-G & 1 & 18.695 & 15.584 & 38.397 & 2.0538 & 0.83358 \\
\hline ATHO-G & 1 & 18.375 & 15.473 & 38.087 & 2.0727 & 0.84205 \\
\hline StHs6/80-G & 1 & 18.894 & 15.609 & 38.496 & 2.0375 & 0.82614 \\
\hline $\mathrm{T} 1-\mathrm{G}$ & 1 & 18.725 & 15.675 & 38.953 & 2.0803 & 0.83715 \\
\hline GOR128-G & 1 & 18.510 & 15.618 & 38.256 & 2.0668 & 0.84377 \\
\hline GOR132-G & 1 & 19.245 & 15.712 & 38.688 & 2.0103 & 0.81644 \\
\hline NIST SRM 981 & & 16.936 & 15.491 & 36.701 & 2.1671 & 0.91466 \\
\hline Reference Material & $\mathrm{N}$ & ${ }^{208} \mathrm{~Pb} /{ }^{206} \mathrm{~Pb}$ & $1 \mathrm{SD}$ & ${ }^{207} \mathrm{~Pb} /{ }^{206} \mathrm{~Pb}$ & $1 \mathrm{SD}$ & \\
\hline \multicolumn{7}{|c|}{ Solution ICPMS $\mathrm{d}$} \\
\hline KL2-G & 3 & 2.021 & 0.004 & 0.8203 & 0.0003 & \\
\hline ML3B-G & 3 & 2.056 & 0.002 & 0.8342 & 0.0014 & \\
\hline ATHO-G & 3 & 2.074 & 0.005 & 0.8423 & 0.0009 & \\
\hline StHs6/80-G & 3 & 2.042 & 0.001 & 0.8256 & 0.0006 & \\
\hline $\mathrm{T} 1-\mathrm{G}$ & 3 & 2.081 & 0.002 & 0.8367 & 0.0008 & \\
\hline GOR128-G & 3 & 2.081 & 0.001 & 0.8479 & 0.0014 & \\
\hline GOR132-G & 3 & 2.007 & 0.005 & 0.8156 & 0.0024 & \\
\hline \multicolumn{7}{|c|}{$L A-I C P M S^{\mathrm{e}}$} \\
\hline KL2-G & 4 & 2.024 & 0.001 & 0.8225 & 0.0001 & \\
\hline ML3B-G & 4 & 2.055 & 0.002 & 0.8317 & 0.0042 & \\
\hline ATHO-G & 4 & 2.073 & 0.001 & 0.8417 & 0.0017 & \\
\hline StHs6/80-G & 4 & 2.036 & 0.006 & 0.8264 & 0.0017 & \\
\hline $\mathrm{T} 1-\mathrm{G}$ & 5 & 2.081 & 0.004 & 0.8382 & 0.0017 & \\
\hline GOR128-G & 2 & 2.068 & 0.006 & 0.8432 & 0.0025 & \\
\hline GOR132-G & 4 & 2.011 & 0.004 & 0.8179 & 0.0016 & \\
\hline
\end{tabular}

\footnotetext{
a Jochum et al. [2005b]. N, number of glass analyses.

${ }^{\mathrm{b}}$ Mean TIMS Pb isotope ratios using different splits $(\mathrm{C}=29)$. In-run precision $(2 \mathrm{RSE})$ is $0.002-0.01 \%$.

${ }^{\mathrm{c}}$ MC-ICPMS $(\mathrm{C}=64)$ measurements of the reference glasses and NIST SRM 981. In-run precision is typically $0.003 \%$.

${ }^{\mathrm{d}}$ Mean $\mathrm{Pb}$ isotope ratios by solution ICPMS using the single collector Element 2 ICP mass spectrometer $(\mathrm{C}=70)$. About 2100 scans have been performed for each analysis.

${ }^{\mathrm{e}} \mathrm{Mean} \mathrm{Pb}$ isotope ratios obtained from three-spot LA-ICPMS analyses of different splits using spot sizes of 60 $160 \mu \mathrm{m}$ and the electrical scan mode of the Element 2 mass spectrometer $(\mathrm{C}=72)$.
}

ble with recommendations of the ISO [Kane, 2002, 2004; Kane et al., 2003]. In this paper we adapt to these recommendations in order to meet the requirements of the certifying procedure.

\subsection{Identification of Qualified Laboratories}

[76] Certification can only be accomplished satisfactorily by laboratories having the technical competence to perform measurements that match certification goals for reference values, particularly recognizing the need to minimize interlaboratory bias and to achieve the appropriate standards of traceability and uncertainty [Kane et al., 2003]. On the basis of ISO Guide 35 [ISO, 1989], at least 15 laboratories are required for interlaboratory programmes. In this interlaboratory programme, 65 laboratories (Table 2) participated in the geochemical characterization of the MPI-DING glasses. Fifty-eight of them are pure geochemistry and the others are applied geochemistry laboratories. More than $95 \%$ of the laboratories were invited to analyze the glasses. The remaining laboratories have been self-selecting, partly by publishing analytical data of the samples. All laboratories were 


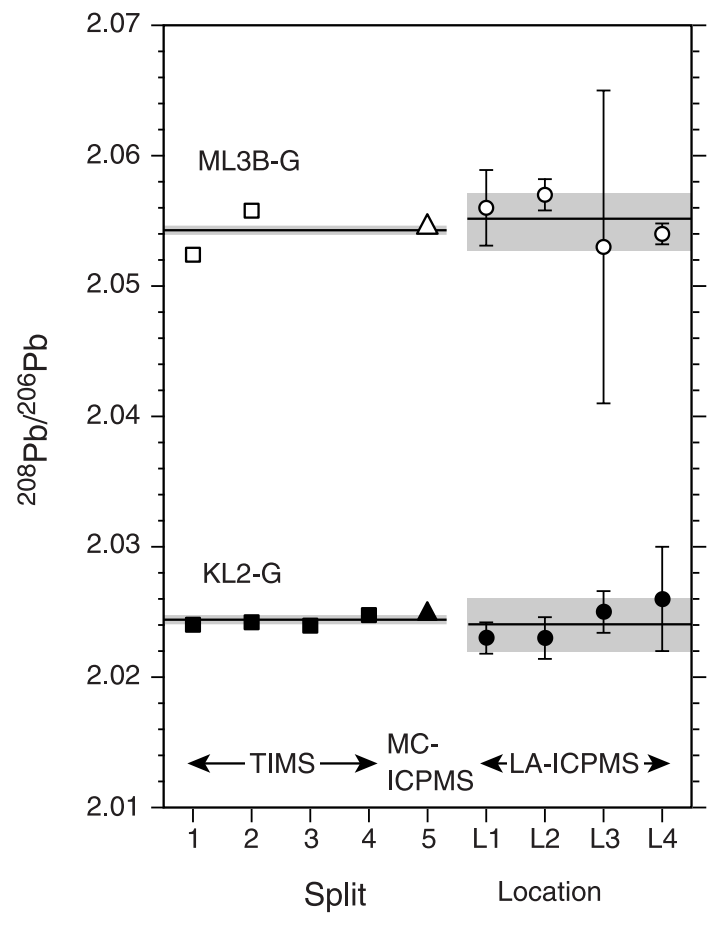

Figure 4. ${ }^{208} \mathrm{~Pb} /{ }^{206} \mathrm{~Pb}$ ratios measured in two MPIDING glasses using four splits for TIMS $(C=29)$ and one split for MC-ICPMS $(\mathrm{C}=64)$. LA-ICPMS spot analyses $(\mathrm{C}=72)$ were performed at different locations of the glasses. The horizontal lines are average values of TIMS/MC-ICPMS and LA-ICPMS data, respectively. The shaded bands represent typical uncertainties (1 SD) of these data. Bars indicate in-run precision ( $\pm 1 \mathrm{SE})$. The figure shows small, but significant, isotopic heterogeneities in the different glass fragments, especially for sample ML3B-G. However, differences are lower than the reproducibility obtained from LAICPMS (and SIMS).

considered as "qualified". According to the IAG protocol [Kane et al., 2003], the competence is assessed for some laboratories by participating in IAG GeoPT ${ }^{\mathrm{TM}}$ proficiency testing programme and interlaboratory standard method evaluations. Competence of all laboratories is assessed on the quality of published research data where issues of error investigation and uncertainty estimation have been evaluated satisfactorily. The collaborating laboratories have demonstrated their technical competence in geochemical research by using thoroughly investigated and well established methods, as well as the publication of reports and research papers describing improvements to "state of the practice" analytical techniques. Four laboratories are equipped to perform isotope dilution by TIMS $(\mathrm{C}=4,53)$, MC-ICPMS $(\mathrm{C}=26,74)$ and ICPMS $(\mathrm{C}=35,48,66)$ using dissolved samples. A special ID-SSMS $(\mathrm{C}=1)$ and ID-MIC-SSMS $(\mathrm{C}=2)$ technique was also applied for some elements. ID is considered to be a definitive method with negligible systematic errors. This is demonstrated in auxiliary material Tables S1a, S1b, and S1h, where most ID-ICPMS data agree with the ID-TIMS values within $2 \mathrm{SD}$.

\subsection{Data Assessment}

[77] Each laboratory submitted their mean results with the respective standard deviations. Nearly all of the analysts also provided the results of all measurements made. A brief description of the method and the procedure used is given in section 2. References for a detailed description of the techniques used are also given. The analytical data of auxiliary material Tables S1a-S1h are accompanied by estimated combined standard uncertainties [Eurachem, 2000]. These uncertainties comprise all components of variance. Some of the components were evaluated from the statistical distribution of the results of series of measurements and were characterized by relative standard deviations (\%). The other components (e.g., calibration error, mass bias), which were also characterized by standard deviations, were evaluated from assumed probability distributions based on experience or other information. As already mentioned, some data are unacceptable presumably because of technical reasons. These outliers were rejected (data are marked). The rejection rates are very low, ranging between $1 \%$ to $3 \%$ for the different glasses.

\subsection{Traceability}

[78] Traceability [King, 1997; Potts, 1997] is a key concept in the characterization of reference samples. It links the validity of all analytical measurements to national and international standards through an unbroken chain of comparisons, for each of which an analytical uncertainty is known at a specified level of confidence [Kane, 2002]. In geochemical research, the USGS rock powders BCR-1, BHVO-1, the NIST glasses and other well-known reference materials can be legitimately viewed as important national and international samples that should be accepted as key links in traceability chains. As shown in section 2 and by Jochum et al. [2000], traceability was established in the results from the various techniques by the use of such international reference materials, for example, to set up the calibration.

[79] Agreement between two or more independent methods and the use of definitive methods, such as 
Table 13a. Summary of Composition Data for $K L 2-G^{a}$

\begin{tabular}{|c|c|c|c|c|c|c|c|c|c|c|c|c|c|c|c|c|}
\hline & \multicolumn{2}{|c|}{ ID } & \multicolumn{2}{|c|}{ ICPMS } & \multicolumn{2}{|c|}{ BULK T. } & \multicolumn{2}{|c|}{ LA-ICPMS } & \multicolumn{2}{|c|}{ MICRO T. } & \multicolumn{2}{|c|}{$\begin{array}{c}\text { All } \\
\text { Techniques }\end{array}$} & \multicolumn{4}{|c|}{ Preferred Value } \\
\hline & Mean & SD & Mean & SD & Mean & $\mathrm{SD}$ & Mean & SD & Mean & $\mathrm{SD}$ & Mean & $\mathrm{SD}$ & Ov. Mean & $\mathrm{U}$ & $\mathrm{n}$ & \\
\hline $\mathrm{H} 2 \mathrm{O}, \% \mathrm{~m} / \mathrm{m}$ & & & & & & & & & 0.015 & & 0.015 & & 0.015 & & & $\overline{\mathrm{Inf}}$ \\
\hline $\mathrm{Li}, \mu \mathrm{g} / \mathrm{g}$ & & & 5.4 & & & & 5.0 & 0.8 & 5.1 & 0.7 & 5.2 & 0.2 & 5.1 & 0.5 & 9 & Ref \\
\hline $\mathrm{Be}, \mu \mathrm{g} / \mathrm{g}$ & & & & & & & 0.73 & 0.11 & 1.11 & 0.32 & 0.92 & 0.27 & 0.88 & 0.34 & 5 & Inf \\
\hline $\mathrm{B}, \mu \mathrm{g} / \mathrm{g}$ & & & & & & & 2.69 & 0.23 & 2.80 & 0.28 & 2.74 & 0.07 & 2.73 & 0.28 & 5 & Inf \\
\hline $\mathrm{CO} 2, \mu \mathrm{g} / \mathrm{g}$ & & & & & & & & & 5.2 & & 5.2 & & 5.2 & & 1 & Inf \\
\hline $\mathrm{O}, \% \mathrm{~m} / \mathrm{m}$ & & & & & & & & & 44.4 & & 44.4 & & 44.4 & & 1 & Inf \\
\hline $\mathrm{F}, \mu \mathrm{g} / \mathrm{g}$ & & & & & & & & & 177 & & 177 & & 177 & & 1 & Inf \\
\hline $\mathrm{Na} 2 \mathrm{O}, \% \mathrm{~m} / \mathrm{m}$ & & & & & 2.24 & 0.08 & & & 2.38 & 0.13 & 2.31 & 0.10 & 2.35 & 0.08 & 14 & Ref \\
\hline $\mathrm{MgO}, \% \mathrm{~m} / \mathrm{m}$ & & & & & 7.35 & & & & 7.34 & 0.16 & 7.35 & 0.01 & 7.34 & 0.09 & 13 & Ref \\
\hline $\mathrm{Al} 2 \mathrm{O} 3, \% \mathrm{~m} / \mathrm{m}$ & & & & & 13.2 & & & & 13.3 & 0.3 & 13.3 & 0.1 & 13.3 & 0.2 & 13 & Ref \\
\hline $\mathrm{SiO} 2, \% \mathrm{~m} / \mathrm{m}$ & & & & & 50.5 & & & & 50.3 & 0.6 & 50.4 & 0.1 & 50.3 & 0.3 & 13 & Ref \\
\hline $\mathrm{P} 2 \mathrm{O} 5, \% \mathrm{~m} / \mathrm{m}$ & & & & & 0.240 & & & & 0.230 & 0.034 & 0.235 & 0.007 & 0.232 & 0.026 & 8 & Ref \\
\hline $\mathrm{S}, \mu \mathrm{g} / \mathrm{g}$ & & & & & & & & & 7.7 & & 7.7 & & 7.7 & & 1 & Inf \\
\hline $\mathrm{g} / \mathrm{g}$ & & & & & & & & & 26 & 5 & 26 & & 26 & & 2 & Inf \\
\hline $\mathrm{K} 2 \mathrm{O}, \% \mathrm{~m} / \mathrm{m}$ & 0.488 & & & & 0.472 & 0.011 & & & 0.480 & 0.020 & 0.480 & 0.008 & 0.480 & 0.010 & 14 & Ref \\
\hline $\mathrm{CaO}, \% \mathrm{~m} / \mathrm{m}$ & & & & & 11.0 & 0.5 & & & 10.9 & 0.4 & 10.9 & 0.0 & 10.9 & 0.2 & 16 & Ref \\
\hline $\mathrm{Sc}, \mu \mathrm{g} / \mathrm{g}$ & & & 31.0 & & 31.0 & 1.3 & 31.7 & 1.8 & 33.6 & 0.8 & 31.8 & 1.2 & 31.8 & 0.9 & 15 & Ref \\
\hline $\mathrm{TiO} 2, \% \mathrm{~m} / \mathrm{m}$ & & & & & 2.52 & & 2.66 & 0.28 & 2.53 & 0.19 & 2.57 & 0.08 & 2.56 & 0.09 & 23 & Ref \\
\hline $\mathrm{V}, \mu \mathrm{g} / \mathrm{g}$ & & & & & & & 288 & 33 & 373 & 80 & 330 & 60 & 309 & 38 & 11 & Ref \\
\hline $\mathrm{Cr}, \mu \mathrm{g} / \mathrm{g}$ & & & & & 285 & 14 & 278 & 22 & 328 & 37 & 297 & 27 & 294 & 27 & 14 & Ref \\
\hline $\mathrm{MnO}, \% \mathrm{~m} / \mathrm{m}$ & & & & & 0.163 & 0.002 & 0.147 & 0.016 & 0.171 & 0.020 & 0.160 & 0.012 & 0.165 & 0.009 & 22 & Ref \\
\hline $\mathrm{FeO} \mathrm{T}, \% \mathrm{~m} / \mathrm{m}$ & & & & & 10.7 & 0.4 & & & 10.7 & 0.2 & 10.7 & & 10.7 & 0.1 & 15 & Ref \\
\hline $\mathrm{Co}, \mu \mathrm{g} / \mathrm{g}$ & & & 43.0 & & 42.2 & 1.6 & 41.1 & 5.2 & 39.7 & 0.5 & 41.5 & 1.4 & 41.2 & 2.3 & 17 & Ref \\
\hline & & & 111 & & 120 & 7 & 110 & 12 & 114 & $\varepsilon$ & 114 & 5 & 112 & 5 & 16 & Ref \\
\hline $\mathrm{Cu}, \mu \mathrm{g} / \mathrm{g}$ & & & 97.0 & & & & 86.4 & 11.1 & 89.5 & 9.2 & 91.0 & 5.4 & 87.9 & 9.1 & 11 & Ref \\
\hline $\mathrm{Zn}, \mu \mathrm{g} / \mathrm{g}$ & & & 116 & & 113 & 10 & 108 & 14 & 109 & 12 & 111 & 4 & 110 & 10 & 11 & Ref \\
\hline $\mathrm{Ga}, \mu \mathrm{g} / \mathrm{g}$ & & & 22.0 & & 19.5 & 0.7 & 20.0 & 2.2 & 19.6 & 2.3 & 20.3 & 1.2 & 20.0 & 1.2 & 12 & Ref \\
\hline $\mathrm{Ge}, \mu \mathrm{g} / \mathrm{g}$ & & & & & & & 1.3 & 0.6 & 1.0 & & 1.2 & 0.2 & 1.3 & 0.8 & 4 & $\operatorname{Inf}$ \\
\hline As, $\mu \mathrm{g} / \mathrm{g}$ & & & & & & & 0.17 & 0.08 & & & 0.17 & & 0.17 & & 2 & $\operatorname{Inf}$ \\
\hline $\mathrm{Se}, \mu \mathrm{g} / \mathrm{g}$ & & & & & & & 0.07 & & & & 0.07 & & 0.07 & & 1 & Inf \\
\hline $\mathrm{Br}, \mu \mathrm{g} / \mathrm{g}$ & & & & & $<0.2$ & & & & & & $<0.2$ & & $<0.2$ & & 1 & Inf \\
\hline & 8.69 & & 8.82 & 0.46 & 10.27 & 0.64 & 8.47 & 0.92 & 7.00 & & 8.65 & 1.16 & 8.70 & 0.40 & 27 & Ref \\
\hline $\mathrm{Sr}$, & 366 & 4 & 367 & 29 & & 23 & & 23 & & 23 & 361 & 9 & 3 & 8 & 32 & Ref \\
\hline $\mathrm{Y}$, & & & 26.8 & 1.5 & 31.3 & 3.3 & 24.1 & 1.9 & 25.9 & 2.4 & 27.0 & 3.1 & 25.4 & 1.1 & 27 & Ref \\
\hline $\mathrm{g}$ & 159 & 5 & 159 & 8 & 169 & 20 & 1 & 10 & 159 & 11 & 157 & 10 & 15 & 5 & 34 & Ref \\
\hline $\mathrm{Nb}, \mu \mathrm{g} / \mathrm{g}$ & & & 15.4 & 0.3 & 16.1 & & 14.8 & 1.1 & 15.0 & 1.2 & 15.3 & 0.6 & 15 & 0.5 & 27 & Ref \\
\hline Mo, $\mu \mathrm{g} / \mathrm{g}$ & & & 3.6 & & 4.3 & 1.0 & 3.3 & 0.7 & 4.0 & & 3.8 & 0.4 & 3.6 & 0.6 & 69 & Ref \\
\hline $\mathrm{Rh}, \mu \mathrm{g} / \mathrm{g}$ & & & & & & & & & 37 & & 37 & & 37 & & 1 & Inf \\
\hline $\mathrm{Pd}, \mu \mathrm{g} / \mathrm{g}$ & & & & & $<6$ & & & & & & $<6$ & & $<6$ & & 1 & \\
\hline $\mathrm{Ag}, \mu \mathrm{g} / \mathrm{g}$ & & & & & & & 0.15 & 0.11 & & & 0.15 & & 015 & & 2 & \\
\hline $\mathrm{g} / \mathrm{g}$ & & & & & & & 0.09 & 0.05 & & & 0.09 & & 0. & & 2 & Inf \\
\hline In, & & & & & & & 0.24 & 0.05 & & & 0.24 & & 0.24 & & 3 & $\operatorname{Inf}$ \\
\hline g & & & 1.60 & & 1.90 & & 1.5 & 0.50 & 1.40 & & 1.60 & & 1. & 0.29 & 13 & Ref \\
\hline & & & 0.16 & & 0.14 & 0.02 & 0.11 & 0.04 & 0.19 & & 0.15 & 0.03 & 4 & 0.03 & 9 & Ref \\
\hline $\mathrm{Cs}$, & & & 0.127 & 0.011 & 0.100 & & 0.108 & 0.021 & 0.120 & & 0.114 & 0.012 & 0.115 & 0.009 & 20 & Ref \\
\hline & 124 & 2 & 125 & 4 & 126 & 5 & 120 & 8 & 126 & $2 J$ & 124 & 3 & 123 & 5 & 32 & Ref \\
\hline $\mathrm{La}, \mu \mathrm{g} / \mathrm{g}$ & 13.3 & & 13.2 & 0.4 & 13.1 & 0.1 & 13.0 & 0.7 & 13.0 & 0.9 & 13.1 & 0.1 & 13.1 & 0.2 & 32 & Ref \\
\hline $\mathrm{Ce}, \mu \mathrm{g} / \mathrm{g}$ & 33.2 & & 32.7 & 1.1 & 33.4 & 0.7 & 32.1 & 2.2 & 31.7 & 2.6 & 32.6 & 0.7 & 32.4 & 0.7 & 30 & Ref \\
\hline $\mathrm{Pr}, \mu \mathrm{g} / \mathrm{g}$ & & & 4.76 & 0.1 & 4.67 & 0.05 & 4.54 & 0.29 & 4.55 & 0.21 & 4.63 & 0.11 & 4.60 & 0.10 & 25 & Ref \\
\hline $\mathrm{Nd}, \mu \mathrm{g} / \mathrm{g}$ & 22.0 & 0.2 & 21.7 & 0.8 & 22.0 & 1.5 & 21.4 & 1.1 & 21.5 & 1.9 & 21.7 & 0.3 & 21.6 & 0.4 & +30 & Ref \\
\hline $\mathrm{Sm}$ & 5.69 & 0.13 & 5.65 & 0.34 & 5.56 & 0.18 & 5.48 & 0.27 & 5.49 & 0.40 & 5.58 & 0.09 & 5.54 & 0.09 & 31 & Ref \\
\hline $\mathrm{Eu}, \mathrm{1}$ & 1.99 & & 2.00 & 0.07 & 1.91 & 0.09 & 1.79 & 0.10 & 1.90 & 0.24 & 1.92 & 0.08 & 1.92 & 0.04 & +32 & Ref \\
\hline $\mathrm{Gd}$, & 6.09 & 0.05 & 6.38 & 0.37 & 6.50 & 1.18 & 5.64 & 0.38 & 6.23 & 0.11 & 6.17 & 0.33 & 5.92 & 0.20 & 29 & Ref \\
\hline & & & 0.933 & 0.040 & 0.923 & 0.059 & 0.851 & 0.075 & 0.986 & & 0.923 & 0.056 & 0.890 & 0.031 & 25 & Ref \\
\hline Dy, $\mu \mathrm{g} / \mathrm{g}$ & 5.44 & 0.06 & 5.37 & 0.27 & 5.34 & 0.25 & 5.10 & 0.38 & 5.15 & 0.32 & 5.28 & 0.15 & 5.22 & 0.12 & 29 & Ref \\
\hline Ho, $\mu \mathrm{g} / \mathrm{g}$ & & & 0.987 & 0.038 & 0.998 & 0.010 & 0.941 & 0.063 & 0.953 & 0.046 & 0.970 & 0.027 & 0.961 & 0.022 & 26 & Ref \\
\hline $\mathrm{Er}, \mu \mathrm{g} / \mathrm{g}$ & 2.67 & 0.09 & 2.66 & 0.15 & 2.67 & 0.10 & 2.46 & 0.17 & 2.53 & 0.26 & 2.60 & 0.10 & 2.54 & 0.07 & 29 & Ref \\
\hline $\mathrm{Tm}, \mu \mathrm{g} / \mathrm{g}$ & & & 0.347 & 0.011 & 0.320 & & 0.325 & 0.020 & 0.320 & & 0.328 & 0.013 & 0.331 & 0.009 & 22 & Ref \\
\hline $\mathrm{Yb}, \mu \mathrm{g} / \mathrm{g}$ & 2.13 & 0.04 & 2.15 & 0.12 & 2.09 & 0.03 & 2.07 & 0.13 & 2.16 & 0.24 & 2.12 & 0.04 & 2.10 & 0.05 & 32 & Ref \\
\hline $\mathrm{Lu}, \mu \mathrm{g} / \mathrm{g}$ & 0.293 & & 0.294 & 0.010 & 0.286 & 0.022 & 0.279 & 0.024 & 0.295 & 0.078 & 0.289 & 0.01 & 0.285 & 0.009 & 30 & Ref \\
\hline
\end{tabular}


Table 13a. (continued)

\begin{tabular}{|c|c|c|c|c|c|c|c|c|c|c|c|c|c|c|c|c|}
\hline & \multicolumn{2}{|c|}{ ID } & \multicolumn{2}{|c|}{ ICPMS } & \multicolumn{2}{|c|}{ BULK T. } & \multicolumn{2}{|c|}{ LA-ICPMS } & \multicolumn{2}{|c|}{ MICRO T. } & \multicolumn{2}{|c|}{$\begin{array}{c}\text { All } \\
\text { Techniques }\end{array}$} & \multicolumn{4}{|c|}{ Preferred Value } \\
\hline & Mean & $\mathrm{SD}$ & Mean & SD & Mean & SD & Mean & SD & Mean & SD & Mean & $\mathrm{SD}$ & Ov. Mean & $\mathrm{U}$ & $\mathrm{n}$ & \\
\hline $\mathrm{Hf}, \mu \mathrm{g} / \mathrm{g}$ & 4.03 & 0.08 & 4.38 & 0.17 & 4.21 & 0.01 & 3.70 & 0.31 & 4.19 & & 4.10 & 0.25 & 3.93 & 0.14 & 26 & Ref \\
\hline $\mathrm{Ta}, \mu \mathrm{g} / \mathrm{g}$ & 0.917 & 0.009 & 0.968 & 0.036 & 0.987 & 0.042 & 0.963 & 0.066 & 0.910 & & 0.949 & 0.034 & 0.961 & 0.022 & 27 & Ref \\
\hline $\mathrm{W}, \mu \mathrm{g} / \mathrm{g}$ & & & & & 0.30 & & 0.38 & 0.06 & & & 0.34 & 0.05 & 0.37 & 0.06 & 7 & Inf \\
\hline $\mathrm{Re}, \mu \mathrm{g} / \mathrm{g}$ & & & & & & & 0.0007 & 0.0002 & & & 0.0007 & & 0.0007 & & 3 & Inf \\
\hline Os, $\mu \mathrm{g} / \mathrm{g}$ & & & & & $<0.3$ & & & & & & $<0.3$ & & $<0.3$ & & 1 & Inf \\
\hline $\mathrm{Ir}, \mu \mathrm{g} / \mathrm{g}$ & & & & & 0.1 & & & & & & 0.1 & & 0.1 & & 1 & Inf \\
\hline $\mathrm{Pt}, \mu \mathrm{g} / \mathrm{g}$ & & & & & 7 & & 10 & & 24 & 21 & 14 & 9 & 16 & & 4 & Inf \\
\hline $\mathrm{Au}, \mu \mathrm{g} / \mathrm{g}$ & & & & & 0.1 & & 0.1 & 0.0 & 1.2 & & 0.5 & 0.6 & 0.4 & & 4 & Inf \\
\hline $\mathrm{Hg}, \mu \mathrm{g} / \mathrm{g}$ & & & & & $<0.3$ & & & & & & $<0.3$ & & $<0.3$ & & 1 & Inf \\
\hline $\mathrm{Tl}, \mu \mathrm{g} / \mathrm{g}$ & & & & & & & 0.0074 & 0.0006 & & & 0.0074 & & 0.0074 & & 2 & Inf \\
\hline $\mathrm{Pb}, \mu \mathrm{g} / \mathrm{g}$ & 1.97 & 0.16 & 2.27 & 0.10 & 2.18 & 0.08 & 2.04 & 0.10 & 2.00 & & 2.09 & 0.13 & 2.07 & 0.10 & 18 & Ref \\
\hline $\mathrm{Bi}, \mu \mathrm{g} / \mathrm{g}$ & & & & & 0.039 & & 0.035 & 0.007 & & & 0.037 & 0.003 & 0.036 & 0.014 & 3 & Inf \\
\hline $\mathrm{Th}, \mu \mathrm{g} / \mathrm{g}$ & 0.971 & & 1.02 & 0.05 & 1.08 & 0.09 & 1.01 & 0.08 & 0.97 & 0.13 & 1.01 & 0.04 & 1.02 & 0.03 & 32 & Ref \\
\hline $\mathrm{U}, \mu \mathrm{g} / \mathrm{g}$ & 0.525 & 0.023 & 0.567 & 0.035 & 0.548 & 0.040 & 0.551 & 0.049 & & & 0.547 & 0.017 & 0.548 & 0.016 & 27 & Ref \\
\hline
\end{tabular}

${ }^{a}$ All techniques mean: average of 1-5 techn. groups means, Ov. (overall) mean: unweighted mean of all results, Ref: reference value, Inf: information value, SD: standard deviation, U: uncertainty at $95 \%$ confidence level, n: number of analyses. BULK T.: XRF, SSMS, MIC-SSMS, MS, INAA, ICP-AES; MICRO T.: EPMA, SIMS, LIMS, SR-XRF, PIXE.

Table 13b. Summary of Composition Data for ML3B-G

\begin{tabular}{|c|c|c|c|c|c|c|c|c|c|c|c|c|c|c|c|c|}
\hline & \multicolumn{2}{|c|}{ ID } & \multicolumn{2}{|c|}{ ICPMS } & \multicolumn{2}{|c|}{ BULK T. } & \multicolumn{2}{|c|}{ LA-ICPMS } & \multicolumn{2}{|c|}{ MICRO T. } & \multicolumn{2}{|c|}{$\begin{array}{c}\text { All } \\
\text { Techniques }\end{array}$} & \multicolumn{4}{|c|}{ Preferred Value } \\
\hline & Mean & SD & Mean & SD & Mean & SD & Mean & SD & Mean & $\mathrm{SD}$ & Mean & $\mathrm{SD}$ & Ov. Mean & $\mathrm{U}$ & $\mathrm{n}$ & \\
\hline $\mathrm{H} 2 \mathrm{O}, \% \mathrm{~m} / \mathrm{m}$ & & & & & & & & & 0.015 & & 0.015 & & 0.015 & & 1 & Inf \\
\hline $\mathrm{Li}, \mu \mathrm{g} / \mathrm{g}$ & & & 4.7 & 0.2 & & & 4.7 & 0.4 & 3.9 & 0.3 & 4.4 & 0.5 & 4.5 & 0.4 & 10 & Ref \\
\hline $\mathrm{Be}, \mu \mathrm{g} / \mathrm{g}$ & & & & & & & 0.58 & 0.10 & 0.75 & & 0.67 & 0.12 & 0.62 & 0.14 & 5 & Inf \\
\hline $\mathrm{B}, \mu \mathrm{g} / \mathrm{g}$ & & & & & & & 2.5 & 0.6 & 2.2 & & 2.4 & 0.2 & 2.5 & 0.6 & 5 & $\operatorname{Inf}$ \\
\hline $\mathrm{CO} 2, \mu \mathrm{g} / \mathrm{g}$ & & & & & & & & & 4.7 & & 4.7 & & 4.7 & & 1 & Inf \\
\hline $\mathrm{O}, \% \mathrm{~m} / \mathrm{m}$ & & & & & & & & & 44.7 & & 44.7 & & 44.7 & & 1 & Inf \\
\hline $\mathrm{F}, \mu \mathrm{g} / \mathrm{g}$ & & & & & & & & & 70 & & 70 & & 70 & & 1 & Inf \\
\hline $\mathrm{Na} 2 \mathrm{O}, \% \mathrm{~m} / \mathrm{m}$ & & & & & 2.35 & 0.04 & & & 2.42 & 0.10 & 2.38 & 0.05 & 2.40 & 0.06 & 13 & Ref \\
\hline $\mathrm{MgO}, \% \mathrm{~m} / \mathrm{m}$ & & & & & 6.56 & 0.11 & & & 6.59 & 0.13 & 6.58 & 0.02 & 6.59 & 0.08 & 13 & Ref \\
\hline $\mathrm{Al} 2 \mathrm{O} 3, \% \mathrm{~m} / \mathrm{m}$ & & & & & 13.3 & 0.4 & & & 13.6 & 0.3 & 13.5 & 0.2 & 13.6 & 0.2 & 13 & Ref \\
\hline $\mathrm{SiO} 2, \% \mathrm{~m} / \mathrm{m}$ & & & & & 50.5 & 2.2 & & & 51.5 & 0.6 & 51.0 & 0.8 & 51.4 & 0.6 & 13 & Ref \\
\hline $\mathrm{P} 2 \mathrm{O} 5, \% \mathrm{~m} / \mathrm{m}$ & & & & & 0.21 & 0.00 & & & 0.23 & 0.03 & 0.222 & 0.018 & 0.230 & 0.025 & 9 & Ref \\
\hline $\mathrm{S}, \mu \mathrm{g} / \mathrm{g}$ & & & & & & & & & 1.2 & & 1.2 & & 1.2 & & 1 & Inf \\
\hline $\mathrm{Cl}, \mu \mathrm{g} / \mathrm{g}$ & & & & & & & & & 7.5 & & 7.5 & & 7.5 & & 1 & $\operatorname{Inf}$ \\
\hline $\mathrm{K} 2 \mathrm{O}, \% \mathrm{~m} / \mathrm{m}$ & 0.386 & & & & 0.382 & 0.008 & & & 0.386 & 0.006 & 0.385 & 0.002 & 0.385 & 0.004 & 14 & Ref \\
\hline $\mathrm{CaO}, \% \mathrm{~m} / \mathrm{m}$ & & & & & 10.5 & 0.20 & & & 10.5 & 0.1 & 10.5 & 0.0 & 10.5 & 0.1 & 14 & Ref \\
\hline $\mathrm{Sc}, \mu \mathrm{g} / \mathrm{g}$ & & & 30.0 & & 30.9 & & 31.6 & 2.9 & 33.7 & & 31.5 & 1.6 & 31.6 & 1.6 & 13 & Ref \\
\hline $\mathrm{TiO} 2, \% \mathrm{~m} / \mathrm{m}$ & & & & & 2.02 & 0.06 & 2.33 & 0.21 & 2.04 & 0.17 & 2.13 & 0.18 & 2.13 & 0.09 & 23 & Ref \\
\hline $\mathrm{V}, \mu \mathrm{g} / \mathrm{g}$ & & & & & 188 & & 277 & 29 & 261 & 43 & 242 & 47 & 268 & 23 & 13 & Ref \\
\hline $\mathrm{Cr}, \mu \mathrm{g} / \mathrm{g}$ & & & & & 152 & 16 & 179 & 44 & 194 & 23 & 175 & 21 & 177 & 23 & 15 & Ref \\
\hline $\mathrm{MnO}, \% \mathrm{~m} / \mathrm{m}$ & & & & & 0.169 & 0.002 & 0.158 & 0.014 & 0.174 & 0.022 & 0.167 & 0.008 & 0.170 & 0.009 & 20 & Ref \\
\hline $\mathrm{FeO} \mathrm{T}, \% \mathrm{~m} / \mathrm{m}$ & & & & & 11.1 & 0.5 & & & 10.9 & 0.2 & 11.0 & 0.2 & 10.9 & 0.1 & 15 & Ref \\
\hline $\mathrm{Co}, \mu \mathrm{g} / \mathrm{g}$ & & & & & 38.4 & 9.0 & 42.0 & 6.0 & 40.2 & & 40.2 & 1.8 & 41.2 & 3.5 & 15 & Ref \\
\hline $\mathrm{Ni}, \mu \mathrm{g} / \mathrm{g}$ & & & 105 & & 125 & 31 & 103 & 9 & 97 & & 107 & 12 & 107 & 9 & 15 & Ref \\
\hline $\mathrm{Cu}, \mu \mathrm{g} / \mathrm{g}$ & & & 121 & & & & 110 & 9 & 117 & & 116 & 6 & 112 & 10 & 9 & Ref \\
\hline $\mathrm{Zn}, \mu \mathrm{g} / \mathrm{g}$ & & & 116 & & 111 & 8 & 102 & 21 & 114 & 8 & 111 & 6 & 108 & 14 & 9 & Ref \\
\hline $\mathrm{Ga}, \mu \mathrm{g} / \mathrm{g}$ & & & 21.0 & & 19.0 & & 18.5 & 2.8 & 23.3 & & 20.4 & 2.2 & 19.6 & 2.1 & 11 & Ref \\
\hline $\mathrm{Ge}, \mu \mathrm{g} / \mathrm{g}$ & & & & & & & 1.2 & 0.8 & 0.9 & & 1.1 & 0.2 & 1.1 & 1.1 & 4 & Inf \\
\hline As, $\mu \mathrm{g} / \mathrm{g}$ & & & & & & & 0.28 & 0.22 & & & 0.28 & & 0.28 & & 3 & Inf \\
\hline $\mathrm{Se}, \mu \mathrm{g} / \mathrm{g}$ & & & & & & & 0.06 & & & & 0.06 & & 0.06 & & 1 & Inf \\
\hline
\end{tabular}


Table 13b. (continued)

\begin{tabular}{|c|c|c|c|c|c|c|c|c|c|c|c|c|c|c|c|c|}
\hline & \multicolumn{2}{|c|}{ ID } & \multicolumn{2}{|c|}{ ICPMS } & \multicolumn{2}{|c|}{ BULK T. } & \multicolumn{2}{|c|}{ LA-ICPMS } & \multicolumn{2}{|c|}{ MICRO T. } & \multicolumn{2}{|c|}{$\begin{array}{c}\text { All } \\
\text { Techniques }\end{array}$} & \multicolumn{4}{|c|}{ Preferred Value } \\
\hline & Mean & $\mathrm{SD}$ & Mean & SD & Mean & SD & Mean & SD & Mean & SD & Mean & SD & Ov. Mean & $\mathrm{U}$ & $\mathrm{n}$ & \\
\hline $\mathrm{Br}, \mu \mathrm{g} / \mathrm{g}$ & & & & & & & & & $<0.2$ & & $<0.2$ & & $<0.2$ & & 1 & Inf \\
\hline $\mathrm{Rb}, \mu \mathrm{g} / \mathrm{g}$ & 5.81 & & 5.76 & 0.20 & & & 5.82 & 0.60 & 5.70 & & 5.77 & 0.06 & 5.80 & 0.21 & 23 & Ref \\
\hline $\mathrm{Sr}, \mu \mathrm{g} / \mathrm{g}$ & 316 & 2 & 312 & 11 & 319 & 16 & 309 & 12 & 319 & 16 & 315 & 4 & 312 & 4 & 30 & Ref \\
\hline $\mathrm{Y}, \mu \mathrm{g} / \mathrm{g}$ & & & 24.7 & 1.5 & 27.6 & & 23.3 & 1.7 & 24.6 & 2.0 & 25.1 & 1.8 & 23.9 & 0.7 & 27 & Ref \\
\hline $\mathrm{Zr}, \mu \mathrm{g} / \mathrm{g}$ & 130 & 4 & 125 & 5 & 137 & 5 & 117 & 8 & 126 & 6 & 127 & 7 & 122 & 3 & 31 & Ref \\
\hline $\mathrm{Nb}, \mu \mathrm{g} / \mathrm{g}$ & & & 8.48 & 0.46 & 9.03 & & 8.43 & 0.38 & 9.38 & 0.70 & 8.83 & 0.46 & 8.61 & 0.22 & 26 & Ref \\
\hline Mo, $\mu \mathrm{g} / \mathrm{g}$ & & & 18.0 & & 18.0 & & 16.1 & 3.4 & 17.3 & & 17.4 & 0.9 & 16.7 & 2.3 & 8 & Ref \\
\hline \multicolumn{17}{|l|}{$\mathrm{Rh}, \mu \mathrm{g} / \mathrm{g}$} \\
\hline \multicolumn{17}{|l|}{$\mathrm{Pd}, \mu \mathrm{g} / \mathrm{g}$} \\
\hline $\mathrm{Ag}, \mu \mathrm{g} / \mathrm{g}$ & & & & & & & 0.03 & & & & 0.03 & & 0.03 & & 1 & Inf \\
\hline $\mathrm{Cd}, \mu \mathrm{g} / \mathrm{g}$ & & & & & & & 0.10 & 0.04 & & & 0.10 & & 0.10 & & 2 & Inf \\
\hline $\mathrm{In}, \mu \mathrm{g} / \mathrm{g}$ & & & & & & & 0.23 & 0.04 & & & 0.23 & & 0.20 & & 3 & Inf \\
\hline $\mathrm{Sn}, \mu \mathrm{g} / \mathrm{g}$ & & & 1.10 & & & & 1.15 & 0.48 & & & 1.12 & 0.03 & 1.14 & 0.33 & 10 & Ref \\
\hline $\mathrm{Sb}, \mu \mathrm{g} / \mathrm{g}$ & & & 0.13 & & & & 0.11 & 0.04 & & & 0.12 & 0.02 & 0.11 & 0.05 & 5 & Inf \\
\hline $\mathrm{Cs}, \mu \mathrm{g} / \mathrm{g}$ & & & 0.148 & 0.010 & & & 0.137 & 0.027 & & & 0.142 & 0.008 & 0.140 & 0.012 & 18 & Ref \\
\hline $\mathrm{Ba}, \mu \mathrm{g} / \mathrm{g}$ & 80.8 & 0.8 & 88.5 & 12.2 & 82.0 & & 79.2 & 4.1 & 78.7 & 8.0 & 81.8 & 4.0 & 80.1 & 2.2 & 26 & Ref \\
\hline $\mathrm{La}, \mu \mathrm{g} / \mathrm{g}$ & 9.04 & & 8.92 & 0.23 & 9.09 & 0.30 & 9.04 & 0.45 & 8.80 & 0.14 & 8.98 & 0.12 & 8.99 & 0.13 & 30 & Ref \\
\hline $\mathrm{Ce}, \mu \mathrm{g} / \mathrm{g}$ & 23.4 & & 22.9 & 0.8 & 24.3 & 0.6 & 23.2 & 0.9 & 22.5 & 1.0 & 23.3 & 0.6 & 23.1 & 0.3 & 29 & Ref \\
\hline $\mathrm{Pr}, \mu \mathrm{g} / \mathrm{g}$ & & & 3.42 & 0.06 & 3.37 & & 3.42 & 0.14 & 3.54 & 0.27 & 3.44 & 0.07 & 3.43 & 0.06 & 524 & Ref \\
\hline $\mathrm{Nd}, \mu \mathrm{g} / \mathrm{g}$ & 16.9 & 0.3 & 16.2 & 0.7 & 16.8 & 0.3 & 16.9 & 0.6 & 16.4 & 1.1 & 16.6 & 0.3 & 16 & 0.2 & 29 & Ref \\
\hline $\mathrm{Sm}, \mu \mathrm{g} / \mathrm{g}$ & 4.78 & 0.02 & 4.64 & 0.23 & 4.78 & 0.16 & 4.74 & 0.24 & 4.85 & 0.01 & 4.76 & 0.07 & 4.75 & 0.07 & 29 & Ref \\
\hline $\mathrm{Eu}, \mu \mathrm{g} / \mathrm{g}$ & 1.71 & & 1.68 & 0.06 & 1.65 & 0.02 & 1.67 & 0.06 & 1.73 & 0.02 & 1.69 & 0.03 & 1.67 & 0.02 & 29 & Ref \\
\hline $\mathrm{Gd}, \mu \mathrm{g} / \mathrm{g}$ & 5.28 & 0.08 & 5.35 & 0.33 & 5.10 & & 5.10 & 0.32 & 5.10 & 0.03 & 5.18 & 0.12 & 5.26 & 0.23 & 28 & Ref \\
\hline $\mathrm{Tb}, \mu \mathrm{g} / \mathrm{g}$ & & & 0.811 & 0.040 & 0.823 & 0.011 & 0.783 & 0.057 & 0.805 & 0.021 & 0.805 & 0.016 & 0.797 & 0.021 & 24 & Ref \\
\hline Dy, $\mu \mathrm{g} / \mathrm{g}$ & 4.90 & 0.11 & 4.84 & 0.23 & 4.83 & 0.30 & 4.84 & 0.21 & 4.71 & 0.24 & 4.82 & 0.07 & 4.84 & 0.07 & 28 & Ref \\
\hline Ho, $\mu \mathrm{g} / \mathrm{g}$ & & & 0.918 & 0.035 & 0.916 & 0.008 & 0.901 & 0.051 & 0.896 & 0.020 & 0.908 & 0.011 & 0.906 & 0.018 & 25 & Ref \\
\hline $\mathrm{Er}, \mu \mathrm{g} / \mathrm{g}$ & 2.52 & 0.10 & 2.45 & 0.13 & 2.45 & & 2.41 & 0.13 & 2.44 & 0.28 & 2.45 & 0.04 & 2.44 & 0.05 & 27 & Ref \\
\hline $\mathrm{Tm}, \mu \mathrm{g} / \mathrm{g}$ & & & 0.324 & 0.008 & & & 0.324 & 0.020 & 0.330 & & 0.326 & 0.004 & 0.324 & 0.007 & 21 & Ref \\
\hline $\mathrm{Yb}, \mu \mathrm{g} / \mathrm{g}$ & 2.04 & 0.02 & 2.01 & 0.08 & 2.15 & 0.04 & 2.06 & 0.12 & 2.08 & 0.05 & 2.07 & 0.05 & 2.06 & 0.04 & +29 & Ref \\
\hline $\mathrm{Lu}, \mu \mathrm{g} / \mathrm{g}$ & 0.287 & & 0.281 & 0.010 & 0.288 & 0.025 & 0.287 & 0.019 & 0.292 & 0.002 & 0.287 & 0.004 & 0.286 & 0.006 & 528 & Ref \\
\hline Hf, $\mu \mathrm{g} / \mathrm{g}$ & 3.28 & 0.08 & 3.45 & 0.05 & 3.51 & 0.29 & 3.14 & 0.20 & 3.25 & 0.13 & 3.32 & 0.15 & 3.22 & 0.08 & 27 & Ref \\
\hline $\mathrm{Ta}, \mu \mathrm{g} / \mathrm{g}$ & 0.529 & 0.005 & 0.570 & 0.030 & 0.563 & & 0.552 & 0.033 & & & 0.553 & 0.018 & 0.555 & 0.013 & 23 & Ref \\
\hline $\mathrm{W}, \mu \mathrm{g} / \mathrm{g}$ & & & & & & & 0.35 & 0.07 & & & 0.35 & & 0.35 & 0.09 & 5 & Inf \\
\hline $\mathrm{Re}, \mu \mathrm{g} / \mathrm{g}$ & & & & & & & 0.0007 & 0.0002 & & & 0.0007 & & 0.0007 & & 2 & Inf \\
\hline \multicolumn{17}{|l|}{ Os, $\mu \mathrm{g} / \mathrm{g}$} \\
\hline $\mathrm{Ir}, \mu \mathrm{g} / \mathrm{g}$ & & & & & 0.03 & & & & & & 0.03 & & 0.03 & & & Inf \\
\hline $\mathrm{Pt}, \mu \mathrm{g} / \mathrm{g}$ & & & & & 6.8 & & 9.7 & & 10.0 & & 8.8 & 1.8 & 8.8 & 8.8 & 3 & Ref \\
\hline $\mathrm{Au}, \mu \mathrm{g} / \mathrm{g}$ & & & & & 0.067 & & 0.064 & 0.034 & & & 0.066 & 0.002 & 0.065 & 0.082 & 23 & Inf \\
\hline $\mathrm{Hg}$, & & & & & $<0.3$ & & & & & & $<0.3$ & & $<0.3$ & & 1 & Inf \\
\hline $\mathrm{Tl}, \mu \mathrm{g} / \mathrm{g}$ & & & & & & & 0.008 & 0.004 & & & 0.008 & & 0.008 & & 2 & Inf \\
\hline $\mathrm{Pb}, \mu \mathrm{g} / \mathrm{g}$ & 1.32 & 0.12 & 1.33 & 0.10 & 1.40 & & 1.40 & 0.15 & & & 1.36 & 0.04 & 1.38 & 0.07 & 16 & Ref \\
\hline $\mathrm{Bi}, \mu \mathrm{g} / \mathrm{g}$ & & & & & 0.010 & & 0.004 & 0.002 & & & 0.007 & 0.004 & 0.006 & 0.009 & 3 & Inf \\
\hline $\mathrm{Th}, \mu \mathrm{g} / \mathrm{g}$ & 0.547 & & 0.534 & 0.014 & 0.565 & 0.021 & 0.550 & 0.030 & & & 0.549 & 0.013 & 0.548 & 0.011 & 26 & Ref \\
\hline $\mathrm{U}, \mu \mathrm{g} / \mathrm{g}$ & 0.427 & 0.014 & 0.436 & 0.021 & 0.438 & 0.045 & 0.448 & 0.055 & & & 0.437 & 0.008 & 0.442 & 0.018 & 26 & Ref \\
\hline
\end{tabular}

${ }^{a}$ All techniques mean: average of 1-5 techn. groups means, Ov. (overall) mean: unweighted mean of all results, Ref: reference value, Inf: information value, SD: standard deviation, U: uncertainty at $95 \%$ confidence level, n: number of analyses. BULK T.: XRF, SSMS, MIC-SSMS, MS, INAA, ICP-AES; MICRO T.: EPMA, SIMS, LIMS, SR-XRF, PIXE.

ID, provide traceability to the fullest extent possible in these circumstances. As already mentioned 16 different analytical techniques were used for the characterization of the MPI-DING glasses (auxiliary material Tables S1a-S1i). Most of them are independent with respect to the use of different sample preparation techniques based on different principles, the use of different calibrants and dif- ferent theoretical bases for the measurements [Kane et al., 2003]. To compare more easily the results obtained from the 16 different techniques (auxiliary material Tables S1a-S1i), we created five major groups of analytical methods. Criteria for this grouping are in particular bulk-microanalytical method, definitive-comparative method, and powdered/dissolved samples. 
Table 13c. Summary of Composition Data for StHs6/80-G ${ }^{\mathrm{a}}$

\begin{tabular}{|c|c|c|c|c|c|c|c|c|c|c|c|c|c|c|c|c|}
\hline & \multicolumn{2}{|c|}{ ID } & \multicolumn{2}{|c|}{ ICPMS } & \multicolumn{2}{|c|}{ BULK T. } & \multicolumn{2}{|c|}{ LA-ICPMS } & \multicolumn{2}{|c|}{ MICRO T. } & \multicolumn{2}{|c|}{$\begin{array}{c}\text { All } \\
\text { Techniques }\end{array}$} & \multicolumn{4}{|c|}{$\begin{array}{l}\text { Preferred } \\
\text { Value }\end{array}$} \\
\hline & Mean & SD & Mean & SD & Mean & SD & Mean & SD & Mean & SD & Mean & SD & Ov. Mean & $\mathrm{U}$ & $\mathrm{n}$ & \\
\hline $\mathrm{H} 2 \mathrm{O}, \% \mathrm{~m} / \mathrm{m}$ & & & & & 0.030 & & & & 0.020 & & 0.025 & 0.007 & 0.025 & & & Inf \\
\hline $\mathrm{Li}, \mu \mathrm{g} / \mathrm{g}$ & & & 21.4 & 3.4 & & & 21.7 & 3.8 & 18.4 & 0.8 & 20.5 & 1.8 & 20.7 & 2.3 & 10 & Ref \\
\hline $\mathrm{Be}, \mu \mathrm{g} / \mathrm{g}$ & & & & & & & 1.1 & 0.1 & 1.3 & 0.1 & 1.2 & 0.1 & 1.2 & 0.1 & 6 & 6 Inf \\
\hline $\mathrm{B}, \mu \mathrm{g} / \mathrm{g}$ & & & & & 11.6 & & 11.9 & 1.8 & 11.6 & 1.3 & 11.7 & 0.2 & 11.8 & 1.3 & 7 & 7 Ref \\
\hline $\mathrm{CO} 2, \mu \mathrm{g} / \mathrm{g}$ & & & & & & & & & 4.4 & & 4.4 & & 4.4 & & 1 & I Inf \\
\hline $\mathrm{O}, \% \mathrm{~m} / \mathrm{m}$ & & & & & & & & & 47.9 & & 47.9 & & 47.9 & & 1 & Inf \\
\hline $\mathrm{F}, \mu \mathrm{g} / \mathrm{g}$ & & & & & & & & & 320 & & 320 & & 320 & & 1 & Inf \\
\hline $\mathrm{Na} 2 \mathrm{O}, \% \mathrm{~m} / \mathrm{m}$ & & & & & 4.59 & 0.11 & & & 4.38 & 0.25 & 4.48 & 0.15 & 4.44 & 0.14 & 13 & 3 Ref \\
\hline $\mathrm{MgO}, \% \mathrm{~m} / \mathrm{m}$ & & & & & 2.01 & 0.01 & & & 1.96 & 0.06 & 1.98 & 0.03 & 1.97 & 0.04 & 13 & 3 Ref \\
\hline $\mathrm{A} 12 \mathrm{O} 3, \% \mathrm{~m} / \mathrm{m}$ & & & & & 17.7 & 0.2 & & & 17.8 & 0.4 & 17.7 & 0.1 & 17.8 & 0.2 & 12 & 2 Ref \\
\hline $\mathrm{SiO} 2, \% \mathrm{~m} / \mathrm{m}$ & & & & & 64.0 & 0.5 & & & 63.6 & 0.8 & 63.8 & 0.2 & 63.7 & 0.5 & 12 & 2 Ref \\
\hline $\mathrm{P} 2 \mathrm{O} 5, \% \mathrm{~m} / \mathrm{m}$ & & & & & 0.160 & 0.000 & & & 0.166 & 0.021 & 0.163 & 0.004 & 0.164 & 0.018 & 6 & 6 Ref \\
\hline $\mathrm{S}, \mu \mathrm{g} / \mathrm{g}$ & & & & & & & & & 2.7 & & 2.7 & & 2.7 & & 1 & Inf \\
\hline $\mathrm{Cl}, \mu \mathrm{g} / \mathrm{g}$ & & & & & & & & & 231 & 39 & 231 & & 231 & 50 & 5 & 5 Ref \\
\hline $\mathrm{K} 2 \mathrm{O}, \% \mathrm{~m} / \mathrm{m}$ & 1.30 & & & & 1.27 & 0.04 & & & 1.30 & 0.04 & 1.29 & 0.02 & 1.29 & 0.02 & 14 & 4 Ref \\
\hline $\mathrm{CaO}, \% \mathrm{~m} / \mathrm{m}$ & & & & & 5.19 & 0.20 & & & 5.32 & 0.11 & 5.26 & 0.10 & 5.28 & 0.09 & 15 & 5 Ref \\
\hline $\mathrm{Sc}, \mu \mathrm{g} / \mathrm{g}$ & & & 9.6 & & 9.8 & 0.2 & 11.9 & 1.3 & 11.8 & 0.4 & 10.8 & 1.3 & 11.5 & 0.8 & 15 & 5 Ref \\
\hline $\mathrm{TiO} 2, \% \mathrm{~m} / \mathrm{m}$ & & & & & 0.688 & 0.011 & 0.746 & 0.065 & 0.683 & 0.026 & 0.705 & 0.035 & 0.703 & 0.021 & 22 & 2 Ref \\
\hline $\mathrm{V}, \mu \mathrm{g} / \mathrm{g}$ & & & & & & & 88.0 & 8.0 & 96.0 & 18.1 & 92.0 & 5.7 & 90.3 & 6.7 & 14 & 4 Ref \\
\hline $\mathrm{Cr}, \mu \mathrm{g} / \mathrm{g}$ & & & & & 19.7 & 9.0 & 15.5 & 3.4 & 17.0 & 7.0 & 17.4 & 2.1 & 16.9 & 3.3 & 15 & 5 Ref \\
\hline $\mathrm{MnO}, \% \mathrm{~m} / \mathrm{m}$ & & & & & 0.075 & 0.004 & 0.072 & 0.004 & 0.078 & 0.011 & 0.075 & 0.003 & 0.076 & 0.004 & 21 & I Ref \\
\hline $\mathrm{FeO} \mathrm{T}, \% \mathrm{~m} / \mathrm{m}$ & & & & & 4.37 & 0.18 & & & 4.37 & 0.12 & 4.37 & 0.00 & 4.37 & 0.07 & 15 & 5 Ref \\
\hline $\mathrm{Co}, \mu \mathrm{g} / \mathrm{g}$ & & & 13.0 & & 12.7 & 0.2 & 13.6 & 1.6 & 11.7 & 4.6 & 12.8 & 0.8 & 13 & 1.1 & 15 & 5 Ref \\
\hline $\mathrm{Ni}, \mu \mathrm{g} / \mathrm{g}$ & & & 22.0 & & 29.5 & 9.2 & 23.4 & 7.1 & 19.7 & 4.7 & 23.7 & 4.2 & 23.7 & 3.8 & 15 & 5 Ref \\
\hline $\mathrm{Cu}, \mu \mathrm{g} / \mathrm{g}$ & & & 40.0 & & & & 42.0 & 13.4 & 40.3 & 1.1 & 40.8 & 1.1 & 41.5 & 8.3 & 10 & Ref \\
\hline $\mathrm{Zn}, \mu \mathrm{g} / \mathrm{g}$ & & & 64 & & 65 & 6 & 71 & 10 & 66 & 7 & 66 & 3 & 67 & 7 & 10 & Ref \\
\hline $\mathrm{Ga}, \mu \mathrm{g} / \mathrm{g}$ & & & 21.0 & & 17.5 & 0.7 & 22.0 & 5.1 & 21.2 & 0.2 & 20.4 & 2.0 & 20.9 & 2.7 & 11 & I Ref \\
\hline $\mathrm{Ge}, \mu \mathrm{g} / \mathrm{g}$ & & & & & & & 1.0 & 0.7 & 1.4 & 0.0 & 1.2 & 0.3 & 1.1 & 0.7 & 5 & 5 Ref \\
\hline As, $\mu \mathrm{g} / \mathrm{g}$ & & & & & 2.10 & 0.14 & 2.89 & 0.66 & 3.05 & 0.35 & 2.68 & 0.51 & 2.73 & 0.48 & 8 & Ref \\
\hline $\mathrm{Se}, \mu \mathrm{g} / \mathrm{g}$ & & & & & & & 0.04 & & & & 0.04 & & 0.04 & & 1 & Inf \\
\hline $\mathrm{Br}$, & & & & & 0.8 & 0.1 & & & 0.7 & & 0.8 & 0.1 & 0.8 & 0.3 & 3 & Inf \\
\hline & 29.5 & & 28.6 & 0.8 & 29.0 & 0.3 & 31.7 & 4.4 & 28.3 & 4.6 & 29.5 & 1.4 & 30.7 & 1.7 & 25 & Ref \\
\hline $\mathrm{Sr}, \mu \mathrm{g} / \mathrm{g}$ & 506 & & 491 & 16 & 482 & 17 & & 21 & 491 & 29 & 489 & 11 & 482 & 8 & 30 & Ref \\
\hline $\mathrm{Y}, \mu \mathrm{g} / \mathrm{g}$ & & & 11.7 & & 10.6 & 0.4 & 11. & 1.1 & 11.4 & 1.4 & 11.3 & 0.5 & 11.4 & 0.4 & 26 & Ref \\
\hline $\mathrm{Zr}, \mu \mathrm{g} / \mathrm{g}$ & 125 & & 124 & 6 & 125 & 5 & 115 & 10 & 119 & 9 & 121 & 4 & 118 & 3 & 31 & Ref \\
\hline $\mathrm{Nb}, \mu \mathrm{g} / \mathrm{g}$ & & & 6.61 & & 8.1 & 0.01 & 6.90 & 0.55 & 7.00 & 0.80 & 7.14 & 0.63 & 6.94 & 0.25 & 25 & Ref \\
\hline Mo, $\mu \mathrm{g} / \mathrm{g}$ & & & 1.8 & & 2.4 & 0.8 & 1.8 & 0.8 & & & 2.0 & 0.3 & 2.0 & 0.6 & 8 & Ref \\
\hline $\mathrm{Rh}, \mu \mathrm{g} / \mathrm{g}$ & & & & & & & & & & & & & & & & \\
\hline $\mathrm{Pd}, \mu \mathrm{g} / \mathrm{g}$ & & & & & $<6$ & & & & & & $<6$ & & $<6$ & & 1 & \\
\hline $\mathrm{Ag}$, & & & & & & & 0.02 & & & & 0.02 & & 0.02 & & 1 & Inf \\
\hline & & & & & & & 0.1 & & & & 0.1 & & 0.1 & & 1 & Inf \\
\hline In, & & & & & & & 0. & 0.5 & & & 0.5 & & 0.5 & & 2 & Inf \\
\hline $\mathrm{Sn}, \mu \mathrm{g} / \mathrm{g}$ & & & 1.0 & & & & 1 & 0.3 & 0.7 & & 1.0 & 0.2 & 1.1 & 0.2 & 10 & Ref \\
\hline $\mathrm{Sb}, \mu \mathrm{g} / \mathrm{g}$ & & & 0.2 & & 0.22 & 0.02 & 0.1 & 0.09 & & & 0.20 & 0.02 & 0.20 & 0.07 & 6 & Ref \\
\hline $\mathrm{Cs}, \mu \mathrm{g} / \mathrm{g}$ & & & 1.59 & 0.13 & 1.96 & 0.06 & 1.7 & 0.23 & 1.89 & & 1.80 & 0.16 & 1.75 & 0.11 & 17 & Ref \\
\hline $\mathrm{Ba}, \mu \mathrm{g} / \mathrm{g}$ & 310 & & 339 & 52 & 300 & 0 & 298 & 15 & 283 & 28 & 306 & 21 & 298 & 9 & 28 & Ref \\
\hline $\mathrm{La}, \mu \mathrm{g} / \mathrm{g}$ & 12.5 & & 11.9 & 0.1 & 11.7 & 0.7 & 12.1 & 0.7 & 11.8 & 0.8 & 12.0 & 0.3 & 12.0 & 0.3 & 28 & Ref \\
\hline $\mathrm{Ce}, \mu \mathrm{g} / \mathrm{g}$ & 26.5 & & 25.6 & 1.3 & 27.5 & 5.0 & 26.3 & 1.2 & 24.5 & 1.2 & 26.1 & 1.1 & 26.1 & 0.7 & 28 & Ref \\
\hline $\mathrm{Pr}, \mu \mathrm{g} / \mathrm{g}$ & & & 3.22 & 0.09 & 3.04 & & 3.21 & 0.16 & 3.15 & 0.05 & 3.15 & 0.08 & 3.20 & 0.06 & 22 & Ref \\
\hline $\mathrm{Nd}, \mu \mathrm{g} / \mathrm{g}$ & 13.5 & & 12.6 & 0.4 & 12.8 & 2.0 & 13.0 & 0.6 & 11.9 & 2.2 & 12.8 & 0.6 & 13.0 & 0.3 & 28 & Ref \\
\hline $\mathrm{g} / \mathrm{g}$ & 2.90 & & 2.81 & 0.17 & 2.81 & 0.10 & 2.79 & 0.12 & 2.63 & 0.14 & 2.79 & 0.10 & 2.78 & 0.05 & 27 & Ref \\
\hline $\mathrm{Eu}, \mathrm{l}$ & 0.987 & & 0.977 & 0.093 & 0.963 & 0.026 & 0.954 & 0.046 & 0.875 & 0.078 & 0.951 & 0.044 & 0.953 & 0.022 & 26 & Ref \\
\hline $\mathrm{Gd}, \mu \mathrm{g} / \mathrm{g}$ & 2.73 & & 2.77 & 0.29 & 2.75 & 0.35 & 2.55 & 0.20 & 2.47 & 0.12 & 2.65 & 0.14 & 2.59 & 0.09 & 26 & Ref \\
\hline $\mathrm{Tb}, \mu \mathrm{g} / \mathrm{g}$ & & & 0.396 & 0.029 & 0.370 & 0.028 & 0.367 & 0.023 & 0.365 & 0.014 & 0.375 & 0.015 & 0.371 & 0.011 & 22 & Ref \\
\hline Dy, $\mu \mathrm{g} / \mathrm{g}$ & 2.32 & & 2.22 & 0.07 & 2.41 & 0.01 & 2.22 & 0.15 & 2.03 & 0.12 & 2.24 & 0.14 & 2.22 & 0.06 & 25 & Ref \\
\hline Ho, $\mu \mathrm{g} / \mathrm{g}$ & & & 0.428 & 0.011 & 0.395 & 0.021 & 0.421 & 0.028 & 0.426 & 0.006 & 0.417 & 0.015 & 0.420 & 0.011 & 22 & Ref \\
\hline $\mathrm{Er}, \mu \mathrm{g} / \mathrm{g}$ & 1.26 & & 1.22 & 0.07 & 0.95 & & 1.19 & 0.08 & 1.18 & 0.07 & 1.16 & 0.12 & 1.18 & 0.04 & 25 & Ref \\
\hline $\mathrm{Tm}, \mu \mathrm{g} / \mathrm{g}$ & & & 0.173 & 0.006 & & & 0.170 & 0.015 & 0.180 & 0.028 & 0.174 & 0.005 & 0.172 & 0.007 & 19 & Ref \\
\hline $\mathrm{Yb}, \mu \mathrm{g} / \mathrm{g}$ & 1.17 & & 1.11 & 0.01 & 1.12 & 0.02 & 1.14 & 0.08 & 1.09 & 0.03 & 1.13 & 0.03 & 1.13 & 0.03 & 28 & Ref \\
\hline
\end{tabular}


Table 13c. (continued)

\begin{tabular}{|c|c|c|c|c|c|c|c|c|c|c|c|c|c|c|c|c|}
\hline & \multicolumn{2}{|c|}{ ID } & \multicolumn{2}{|c|}{ ICPMS } & \multicolumn{2}{|c|}{ BULK T. } & \multicolumn{2}{|c|}{ LA-ICPMS } & \multicolumn{2}{|c|}{ MICRO T. } & \multicolumn{2}{|c|}{$\begin{array}{c}\text { All } \\
\text { Techniques }\end{array}$} & \multicolumn{4}{|c|}{$\begin{array}{l}\text { Preferred } \\
\text { Value }\end{array}$} \\
\hline & Mean & $\mathrm{SD}$ & Mean & SD & Mean & $\mathrm{SD}$ & Mean & $\mathrm{SD}$ & Mean & SD & Mean & SD & Ov. Mean & $\mathrm{U}$ & $\mathrm{n}$ & \\
\hline $\mathrm{Lu}, \mu \mathrm{g} / \mathrm{g}$ & 0.174 & & 0.170 & 0.000 & 0.167 & 0.006 & 0.166 & 0.017 & 0.179 & 0.020 & 0.171 & 0.005 & 0.168 & 0.006 & 27 & Ref \\
\hline Hf, $\mu \mathrm{g} / \mathrm{g}$ & 3.23 & 0.12 & 3.25 & 0.04 & 3.28 & 0.04 & 2.98 & 0.21 & 3.14 & 0.05 & 3.17 & 0.12 & 3.07 & 0.09 & 24 & Ref \\
\hline $\mathrm{Ta}, \mu \mathrm{g} / \mathrm{g}$ & 0.403 & 0.004 & 0.410 & & 0.421 & 0.001 & 0.423 & 0.036 & & & 0.414 & 0.010 & 0.420 & 0.015 & 21 & Ref \\
\hline $\mathrm{W}, \mu \mathrm{g} / \mathrm{g}$ & & & & & & & 0.47 & 0.17 & & & 0.47 & & 0.47 & 0.18 & 6 & Inf \\
\hline $\mathrm{Re}, \mu \mathrm{g} / \mathrm{g}$ & & & & & & & 0.0009 & 0.0006 & & & 0.0009 & & 0.0009 & 0.0017 & 3 & Inf \\
\hline Os, $\mu \mathrm{g} / \mathrm{g}$ & & & & & $<1$ & & & & & & $<1$ & & $<1$ & & 1 & Inf \\
\hline $\mathrm{Ir}, \mu \mathrm{g} / \mathrm{g}$ & & & & & 0.02 & & & & & & 0.02 & & 0.02 & & 2 & Inf \\
\hline $\mathrm{Pt}, \mu \mathrm{g} / \mathrm{g}$ & & & & & & & 1 & & & & 1 & & 1 & & 1 & Inf \\
\hline $\mathrm{Au}, \mu \mathrm{g} / \mathrm{g}$ & & & & & 0.042 & 0.000 & 0.053 & 0.004 & & & 0.048 & 0.008 & 0.048 & 0.032 & 4 & Inf \\
\hline $\mathrm{Hg}, \mu \mathrm{g} / \mathrm{g}$ & & & & & $<0.2$ & & & & & & $<0.2$ & & $<0.2$ & & 1 & Inf \\
\hline $\mathrm{Tl}, \mu \mathrm{g} / \mathrm{g}$ & & & & & & & 0.11 & 0.02 & & & 0.11 & & 0.11 & & 3 & Inf \\
\hline $\mathrm{Pb}, \mu \mathrm{g} / \mathrm{g}$ & & & 9.66 & 0.36 & & & 10.4 & 1.97 & 9.95 & 1.34 & 10.0 & 0.4 & 10.3 & 0.9 & 16 & Ref \\
\hline $\mathrm{Bi}, \mu \mathrm{g} / \mathrm{g}$ & & & & & 0.13 & & 0.10 & 0.05 & & & 0.11 & 0.02 & 0.11 & 0.07 & 4 & Inf \\
\hline $\mathrm{Th}, \mu \mathrm{g} / \mathrm{g}$ & & & 2.27 & 0.04 & 2.19 & 0.06 & 2.30 & 0.21 & 2.21 & & 2.24 & 0.05 & 2.28 & 0.07 & 25 & Ref \\
\hline $\mathrm{U}, \mu \mathrm{g} / \mathrm{g}$ & & & 0.98 & 0.03 & 1.02 & 0.13 & 1.02 & 0.11 & & & 1.01 & 0.02 & 1.01 & 0.04 & 24 & Ref \\
\hline
\end{tabular}

Table 13d. Summary of Composition Data for GOR128-G ${ }^{\mathrm{a}}$

\begin{tabular}{|c|c|c|c|c|c|c|c|c|c|c|c|c|c|c|}
\hline & ID & \multicolumn{2}{|c|}{ ICPMS } & \multicolumn{2}{|c|}{ BULK T. } & \multicolumn{2}{|c|}{ LA-ICPMS } & \multicolumn{2}{|c|}{ MICRO T. } & \multicolumn{2}{|c|}{$\begin{array}{c}\text { All } \\
\text { Techniques }\end{array}$} & \multicolumn{3}{|c|}{ Preferred Value } \\
\hline & Mean SD & Mean & SD & Mean & SD & Mean & SD & Mean & SD & Mean & SD & Ov. Mean & $\mathrm{U}$ & $\mathrm{n}$ \\
\hline $\mathrm{H} 2 \mathrm{O}, \% \mathrm{~m} / \mathrm{m}$ & & & & & & & & 0.026 & & 0.026 & & 0.026 & & 1 Inf \\
\hline $\mathrm{Li}, \mu \mathrm{g} / \mathrm{g}$ & & 9.9 & 0.2 & & & 12.2 & 1.5 & 7.1 & 0.4 & 9.7 & 2.5 & 10.4 & 1.7 & 11 Ref \\
\hline $\mathrm{Be}, \mu \mathrm{g} / \mathrm{g}$ & & & & & & 0.033 & 0.005 & 0.037 & 0.005 & 0.035 & 0.003 & 0.034 & 0.007 & $4 \operatorname{Inf}$ \\
\hline $\mathrm{B}, \mu \mathrm{g} / \mathrm{g}$ & & & & 22.7 & & 24.8 & 3.1 & 20.4 & 2.0 & 22.6 & 2.2 & 23.5 & 2.8 & 7 Ref \\
\hline $\mathrm{CO} 2, \mu \mathrm{g} / \mathrm{g}$ & & & & & & & & 4.4 & & 4.4 & & 4.4 & & 1 Inf \\
\hline $\mathrm{O}, \% \mathrm{~m} / \mathrm{m}$ & & & & & & & & 44.4 & & 44.4 & & 44.4 & & 1 Inf \\
\hline $\mathrm{F}, \mu \mathrm{g} / \mathrm{g}$ & & & & & & & & 25 & & 25 & & 25 & & 1 Inf \\
\hline $\mathrm{Na} 2 \mathrm{O}, \% \mathrm{~m} / \mathrm{m}$ & & & & 0.548 & 0.025 & & & 0.588 & 0.030 & 0.568 & 0.028 & 0.574 & 0.026 & 9 Ref \\
\hline $\mathrm{MgO}, \% \mathrm{~m} / \mathrm{m}$ & & & & 26.1 & 0.1 & & & 25.9 & 0.5 & 26.0 & 0.1 & 26.0 & 0.3 & 10 Ref \\
\hline $\mathrm{A} 12 \mathrm{O} 3, \% \mathrm{~m} / \mathrm{m}$ & & & & 9.93 & 0.25 & & & 9.90 & 0.24 & 9.91 & 0.02 & 9.91 & 0.17 & $9 \operatorname{Inf}$ \\
\hline $\mathrm{SiO} 2, \% \mathrm{~m} / \mathrm{m}$ & & & & 46.6 & 0.8 & & & 45.9 & 0.5 & 46.3 & 0.5 & 46.1 & 0.4 & 11 Ref \\
\hline $\mathrm{P} 2 \mathrm{O} 5, \% \mathrm{~m} / \mathrm{m}$ & & & & 0.028 & 0.004 & 0.020 & & 0.025 & 0.005 & 0.024 & 0.004 & 0.025 & 0.005 & 6 Ref \\
\hline $\mathrm{S}, \mu \mathrm{g} / \mathrm{g}$ & & & & & & & & 4.3 & & 4.3 & & 4.3 & & $1 \mathrm{Inf}$ \\
\hline $\mathrm{Cl}, \mu \mathrm{g} / \mathrm{g}$ & & & & & & & & 12 & & 12 & & 12 & & 1 Inf \\
\hline $\mathrm{K} 2 \mathrm{O}, \% \mathrm{~m} / \mathrm{m}$ & 0.035 & & & 0.037 & 0.003 & & & 0.036 & 0.010 & 0.036 & 0.001 & 0.036 & 0.005 & 11 Ref \\
\hline $\mathrm{CaO}, \% \mathrm{~m} / \mathrm{m}$ & & & & 6.14 & 0.23 & 6.65 & & 6.23 & 0.11 & 6.34 & 0.27 & 6.24 & 0.12 & $12 \operatorname{Ref}$ \\
\hline $\mathrm{Sc}, \mu \mathrm{g} / \mathrm{g}$ & & 30.0 & & 30.2 & & 32.5 & 1.8 & & & 30.9 & 1.4 & 32.1 & 1.4 & 10 Ref \\
\hline $\mathrm{TiO} 2, \% \mathrm{~m} / \mathrm{m}$ & & & & 0.283 & 0.004 & 0.302 & 0.032 & 0.279 & 0.007 & 0.288 & 0.013 & 0.288 & 0.012 & 16 Ref \\
\hline $\mathrm{V}, \mu \mathrm{g} / \mathrm{g}$ & & & & 170 & & 191 & 17 & & & 181 & 15 & 189 & 13 & 10 Ref \\
\hline $\mathrm{Cr}, \mu \mathrm{g} / \mathrm{g}$ & & & & 2120 & 35 & 2364 & 222 & 2210 & 78 & 2231 & 124 & 2272 & 171 & 18 Ref \\
\hline$\% \mathrm{~m} / \mathrm{m}$ & & & & 0.172 & 0.006 & 0.183 & 0.030 & 0.176 & 0.014 & 0.177 & 0.005 & 0.176 & 0.009 & 14 Ref \\
\hline $\mathrm{FeO} \mathrm{T}, \% \mathrm{~m} / \mathrm{m}$ & & & & 9.82 & 0.18 & & & 9.82 & 0.19 & 9.82 & 0.00 & 9.81 & 0.12 & 11 Ref \\
\hline $\mathrm{Co}, \mu \mathrm{g} / \mathrm{g}$ & & 81.0 & & 78.8 & 8.2 & 95.7 & 9.8 & & & 85.2 & 9.2 & 92.4 & 6.2 & 15 Ref \\
\hline $\mathrm{Ni}, \mu \mathrm{g} / \mathrm{g}$ & & & & 1070 & 44 & 1076 & 106 & & & 1073 & 4 & 1074 & 61 & 11 Ref \\
\hline $\mathrm{Cu}, \mu \mathrm{g} / \mathrm{g}$ & & $\mathbf{5 7 . 0}$ & & & & 64.5 & 17.3 & & & 60.8 & 5.3 & 63.8 & 12.5 & 10 Ref \\
\hline $\mathrm{Zn}, \mu \mathrm{g} / \mathrm{g}$ & & 72.0 & & 75.5 & 0.7 & 75.0 & 4.6 & & & 74.2 & 1.9 & 74.7 & 6.7 & 6 Ref \\
\hline $\mathrm{Ga}, \mu \mathrm{g} / \mathrm{g}$ & & 9.10 & & 8.28 & & 9.04 & 1.11 & & & 8.81 & 0.46 & 8.67 & 1.07 & 7 Ref \\
\hline $\mathrm{Ge}, \mu \mathrm{g} / \mathrm{g}$ & & & & & & 0.96 & 0.01 & & & 0.96 & & 0.96 & & $2 \mathrm{Inf}$ \\
\hline As, & & & & & & $<0.1$ & & & & $<0.1$ & & $<0.1$ & & $1 \mathrm{Inf}$ \\
\hline $\mathrm{Se}, \mu \mathrm{g} / \mathrm{g}$ & & & & & & $<0.03$ & & & & $<\mathbf{0 . 0 3}$ & & $<\mathbf{0 . 0 3}$ & & $1 \mathrm{Inf}$ \\
\hline $\mathrm{Br}, \mu \mathrm{g} / \mathrm{g}$ & & & & $<0.3$ & & & & & & $<0.3$ & & $<0.3$ & & $1 \mathrm{Inf}$ \\
\hline $\mathrm{Rb}, \mu \mathrm{g} / \mathrm{g}$ & 0.373 & 0.470 & 0.036 & & & 0.395 & 0.043 & & & 0.413 & 0.051 & 0.406 & 0.025 & 18 Ref \\
\hline
\end{tabular}


Table 13d. (continued)

\begin{tabular}{|c|c|c|c|c|c|c|c|c|c|c|c|c|c|c|}
\hline & ID & \multicolumn{2}{|c|}{ ICPMS } & \multicolumn{2}{|c|}{ BULK T. } & \multicolumn{2}{|c|}{ LA-ICPMS } & \multicolumn{2}{|c|}{ MICRO T. } & \multicolumn{2}{|c|}{$\begin{array}{c}\text { All } \\
\text { Techniques }\end{array}$} & \multicolumn{3}{|c|}{ Preferred Value } \\
\hline & Mean SD & Mean & SD & Mean & SD & Mean & SD & Mean & $\mathrm{SD}$ & Mean & $\mathrm{SD}$ & Ov. Mean & $\mathrm{U}$ & $\mathrm{n}$ \\
\hline $\mathrm{Sr}, \mu \mathrm{g} / \mathrm{g}$ & 33.1 & 30.9 & 2.7 & 34.0 & & 29.5 & 1.9 & 28.6 & & 31.2 & 2.3 & 30.0 & 1.0 & $21 \mathrm{Ref}$ \\
\hline $\mathrm{Y}, \mu \mathrm{g} / \mathrm{g}$ & & 12.3 & 1.0 & 10.0 & & 11.8 & 1.2 & 12.1 & & 11.6 & 1.1 & 11.8 & 0.5 & 21 Ref \\
\hline $\mathrm{Zr}, \mu \mathrm{g} / \mathrm{g}$ & 10.1 & 10.9 & 1.2 & 10.4 & & 9.8 & 1.1 & 10.3 & & 10.3 & 0.4 & 10.0 & 0.5 & 23 Ref \\
\hline $\mathrm{Nb}, \mu \mathrm{g} / \mathrm{g}$ & & 0.118 & 0.017 & 0.101 & & 0.096 & 0.012 & & & 0.105 & 0.012 & 0.099 & 0.007 & 18 Ref \\
\hline Mo, $\mu \mathrm{g} / \mathrm{g}$ & & 0.60 & & & & 0.73 & 0.27 & & & 0.66 & 0.09 & 0.71 & 0.26 & $6 \mathrm{Inf}$ \\
\hline \multicolumn{15}{|l|}{$\mathrm{Rh}, \mu \mathrm{g} / \mathrm{g}$} \\
\hline $\mathrm{Pd}, \mu \mathrm{g} / \mathrm{g}$ & & & & & & & & & & & & & & \\
\hline $\mathrm{Ag}, \mu \mathrm{g} / \mathrm{g}$ & & & & $<0.5$ & & & & & & $<0.5$ & & $<0.5$ & & $1 \operatorname{Inf}$ \\
\hline $\mathrm{Cd}, \mu \mathrm{g} / \mathrm{g}$ & & & & & & 0.072 & 0.003 & & & 0.072 & & 0.072 & & $2 \operatorname{Inf}$ \\
\hline $\mathrm{In}, \mu \mathrm{g} / \mathrm{g}$ & & & & & & 0.067 & 0.029 & & & 0.067 & & 0.067 & & $3 \mathrm{Inf}$ \\
\hline $\mathrm{Sn}, \mu \mathrm{g} / \mathrm{g}$ & & 0.220 & & & & 0.225 & 0.096 & & & 0.223 & 0.004 & 0.224 & 0.092 & 6 In \\
\hline $\mathrm{Sb}, \mu \mathrm{g} / \mathrm{g}$ & & 0.020 & & & & 0.006 & 0.002 & & & 0.013 & 0.010 & 0.010 & 0.021 & $3 \operatorname{Inf}$ \\
\hline $\mathrm{Cs}, \mu \mathrm{g} / \mathrm{g}$ & & 0.233 & 0.016 & 0.290 & & 0.237 & 0.052 & & & 0.253 & 0.032 & 0.240 & 0.025 & $16 \mathrm{Re}$ \\
\hline $\mathrm{Ba}, \mu \mathrm{g} / \mathrm{g}$ & 1.09 & 1.04 & & & & 1.06 & 0.07 & 1.00 & & 1.05 & 0.04 & 1.06 & 0.03 & $20 \mathrm{Re}$ \\
\hline $\mathrm{La}, \mu \mathrm{g} / \mathrm{g}$ & 0.129 & 0.130 & 0.011 & 0.110 & & 0.118 & 0.007 & 0.140 & & 0.125 & 0.012 & 0.121 & 0.004 & 23 Ref \\
\hline $\mathrm{Ce}, \mu \mathrm{g} / \mathrm{g}$ & 0.487 & 0.448 & 0.039 & 0.530 & & 0.446 & 0.028 & 0.400 & & 0.462 & 0.049 & 0.450 & 0.016 & $21 \mathrm{Re}$ \\
\hline $\operatorname{Pr}, \mu \mathrm{g} / \mathrm{g}$ & & 0.110 & 0.011 & 0.104 & & 0.098 & 0.005 & & & 0.104 & 0.006 & 0.100 & 0.004 & 19 Ref \\
\hline $\mathrm{Nd}, \mu \mathrm{g} / \mathrm{g}$ & 0.881 & 0.754 & 0.044 & 0.789 & & 0.783 & 0.101 & 0.790 & & 0.800 & 0.048 & 0.784 & 0.047 & 22 Ref \\
\hline $\mathrm{Sm}, \mu \mathrm{g} / \mathrm{g}$ & 0.604 & 0.535 & 0.052 & 0.558 & 0.085 & 0.514 & 0.039 & 0.530 & & 0.548 & 0.035 & 0.525 & 0.020 & $23 \mathrm{Re}$ \\
\hline $\mathrm{Eu}, \mu \mathrm{g} / \mathrm{g}$ & 0.306 & 0.264 & 0.014 & 0.245 & 0.006 & 0.263 & 0.016 & 0.290 & & 0.274 & 0.024 & 0.264 & 0.008 & 24 Ref \\
\hline $\mathrm{Gd}, \mu \mathrm{g} / \mathrm{g}$ & 1.40 & 1.19 & 0.01 & 1.20 & 0.42 & 1.15 & 0.11 & & & 1.23 & 0.11 & 1.17 & 0.04 & $21 \mathrm{Re}$ \\
\hline $\mathrm{Tb}, \mu \mathrm{g} / \mathrm{g}$ & & 0.259 & 0.011 & 0.235 & 0.035 & 0.247 & 0.025 & & & 0.247 & 0.012 & 0.248 & 0.012 & 17 Ref \\
\hline Dy, $\mu \mathrm{g} / \mathrm{g}$ & 2.30 & 1.96 & 0.09 & 1.93 & 0.01 & 1.97 & 0.18 & 1.89 & & 2.01 & 0.17 & 1.98 & 0.07 & $23 \mathrm{Re}$ \\
\hline $\mathrm{Ho}, \mu \mathrm{g} / \mathrm{g}$ & & 0.450 & 0.021 & 0.434 & 0.037 & 0.443 & 0.044 & & & 0.442 & 0.008 & 0.443 & 0.019 & $19 \mathrm{Re}$ \\
\hline $\mathrm{Er}, \mu \mathrm{g} / \mathrm{g}$ & 1.67 & 1.41 & 0.09 & 1.43 & & 1.40 & 0.14 & 1.17 & & 1.42 & 0.18 & 1.40 & 0.06 & 21 Ref \\
\hline $\mathrm{Tm}, \mu \mathrm{g} / \mathrm{g}$ & & 0.206 & 0.006 & 0.180 & & 0.205 & 0.018 & & & 0.197 & 0.015 & 0.204 & 0.009 & $17 \mathrm{Re}$ \\
\hline $\mathrm{Yb}, \mu \mathrm{g} / \mathrm{g}$ & 1.63 & 1.37 & 0.06 & 1.50 & 0.22 & 1.41 & 0.14 & 1.15 & & 1.41 & 0.18 & 1.41 & 0.06 & 23 Ref \\
\hline $\mathrm{Lu}, \mu \mathrm{g} / \mathrm{g}$ & 0.250 & 0.205 & 0.009 & 0.215 & 0.007 & 0.203 & 0.021 & & & 0.218 & 0.022 & 0.206 & 0.009 & 22 Ref \\
\hline $\mathrm{Hf}, \mu \mathrm{g} / \mathrm{g}$ & $\mathbf{0 . 3 5 3} 0.013$ & 0.375 & 0.047 & 0.344 & & 0.343 & 0.036 & & & 0.354 & 0.015 & 0.349 & 0.017 & 20 Ref \\
\hline $\mathrm{Ta}, \mu \mathrm{g} / \mathrm{g}$ & $\mathbf{0 . 0 2 4} 0.000$ & & & & & 0.019 & 0.002 & & & 0.021 & 0.003 & 0.019 & 0.001 & $13 \operatorname{Ref}$ \\
\hline $\mathrm{W}, \mu \mathrm{g} / \mathrm{g}$ & & & & 14.3 & & 15.7 & 2.4 & & & 15.0 & 1.0 & 15.5 & 2.4 & $6 \operatorname{Inf}$ \\
\hline $\mathrm{Re}, \mu \mathrm{g} / \mathrm{g}$ & & & & & & 0.0006 & 0.00004 & & & 0.0006 & & 0.0006 & & $2 \mathrm{Inf}$ \\
\hline \multicolumn{15}{|l|}{ Os, $\mu \mathrm{g} / \mathrm{g}$} \\
\hline $\mathrm{Ir}, \mu \mathrm{g} / \mathrm{g}$ & & & & 0.063 & & & & & & 0.063 & & 0.063 & & $1 \operatorname{Inf}$ \\
\hline $\mathrm{Pt}, \mu \mathrm{g} / \mathrm{g}$ & & & & 9.6 & & 12.6 & & & & 11.1 & 2.1 & 11.1 & & $2 \operatorname{Inf}$ \\
\hline $\mathrm{Au}, \mu \mathrm{g} / \mathrm{g}$ & & & & 0.028 & & 0.021 & & & & 0.024 & 0.005 & 0.024 & & $2 \mathrm{In}$ \\
\hline $\mathrm{Hg}, \mu \mathrm{g} / \mathrm{g}$ & & & & $<0.2$ & & & & & & $<0.2$ & & $<0.2$ & & $1 \mathrm{In}$ \\
\hline $\mathrm{Tl}, \mu \mathrm{g} / \mathrm{g}$ & & & & & & $<\mathbf{0 . 0 0 3}$ & & & & $<0.003$ & & $<0.003$ & & $1 \mathrm{In}$ \\
\hline $\mathrm{Pb}, \mu \mathrm{g} / \mathrm{g}$ & & 0.415 & 0.120 & 0.340 & & 0.332 & 0.064 & & & 0.362 & 0.046 & 0.345 & 0.043 & 14 Ref \\
\hline $\mathrm{Bi}, \mu \mathrm{g} / \mathrm{g}$ & & & & 0.0009 & & & & & & 0.0009 & & 0.0009 & & $1 \operatorname{Inf}$ \\
\hline $\mathrm{Th}, \mu \mathrm{g} / \mathrm{g}$ & & 0.010 & & 0.006 & & 0.008 & 0.002 & 0.012 & & 0.009 & 0.003 & 0.008 & 0.001 & $15 \operatorname{Ref}$ \\
\hline $\mathrm{U}, \mu \mathrm{g} / \mathrm{g}$ & & 0.0140 & 0.0053 & 0.0140 & & 0.0118 & 0.0015 & & & 0.0133 & 0.001 & 0.0123 & 0.0012 & $18 \operatorname{Ref}$ \\
\hline
\end{tabular}

aAll techniques mean: average of 1-5 techn. groups means, Ov. (overall) mean: unweighted mean of all results, Ref: reference value, Inf: information value, SD: standard deviation, U: uncertainty at $95 \%$ confidence level, $n$ : number of analyses. BULK T.: XRF, SSMS, MIC-SSMS, MS, INAA, ICP-AES; MICRO T.: EPMA, SIMS, LIMS, SR-XRF, PIXE.

\subsubsection{Bulk Analytical Techniques}

[80] Isotope dilution (ID using TIMS, MC-ICPMS, ICPMS): ID is a definitive method and delivers data of very high quality with respect to precision and accuracy. ISO Guide 35 [ISO, 1989] specifically encourages use of definitive methods for the characterization of reference materials. Measurements were made directly in terms of base SI units. For ID analysis, samples were spiked and dissolved.
[81] ICPMS methods (ICPMS using single and multicollector instruments): ICPMS is a modern bulk analytical technique, which uses dissolved samples (typically about 50-100 mg sample amount) for analysis. Data were generally calibrated with certified standard solutions.

[82] Other bulk analytical techniques (XRF, SSMS, MIC-SSMS, MS, INAA, ICP-AES): With the exception of ICP-AES these techniques use powdered samples without chemical treatment. 
Table 13e. Summary of Composition Data for GOR $132-G^{a}$

\begin{tabular}{|c|c|c|c|c|c|c|c|c|c|c|c|c|c|c|c|}
\hline & \multicolumn{2}{|c|}{ ID } & \multicolumn{2}{|c|}{ ICPMS } & \multicolumn{2}{|c|}{ BULK T. } & \multicolumn{2}{|c|}{ LA-ICPMS } & \multicolumn{2}{|c|}{ MICRO T. } & \multicolumn{2}{|c|}{$\begin{array}{c}\text { All } \\
\text { Techniques }\end{array}$} & \multicolumn{3}{|c|}{ Preferred Value } \\
\hline & Mean & SD & Mean & $\mathrm{SD}$ & Mean & SD & Mean & SD & Mean & SD & Mean & $\mathrm{SD}$ & Ov. Mean & $\mathrm{U}$ & $\mathrm{n}$ \\
\hline $\mathrm{H} 2 \mathrm{O}, \% \mathrm{~m} / \mathrm{m}$ & & & & & & & & & 0.026 & & 0.026 & & 0.026 & & $1 \mathrm{Inf}$ \\
\hline $\mathrm{Li}, \mu \mathrm{g} / \mathrm{g}$ & & & 9.5 & 0.6 & & & 9.6 & 1.0 & 6.9 & 0.2 & 8.7 & 1.5 & 8.9 & 1.2 & 8 Ref \\
\hline $\mathrm{Be}, \mu \mathrm{g} / \mathrm{g}$ & & & & & & & 0.10 & 0.08 & 0.04 & & 0.07 & 0.04 & 0.08 & & $3 \mathrm{Inf}$ \\
\hline $\mathrm{B}, \mu \mathrm{g} / \mathrm{g}$ & & & & & 15.6 & & 17.6 & 2.6 & 17.8 & & 17.0 & 1.2 & 17.2 & 2.6 & 5 Ref \\
\hline $\mathrm{CO} 2, \% \mathrm{~m} / \mathrm{m}$ & & & & & & & & & 5.8 & & 5.8 & & 5.8 & & $1 \mathrm{Inf}$ \\
\hline $\mathrm{O}, \% \mathrm{~m} / \mathrm{m}$ & & & & & & & & & 44.0 & & 44.0 & & 44.0 & & $1 \mathrm{Inf}$ \\
\hline $\mathrm{F}, \mu \mathrm{g} / \mathrm{g}$ & & & & & & & & & 22 & & 22 & & 22 & & 1 Inf \\
\hline $\mathrm{Na} 2 \mathrm{O}, \% \mathrm{~m} / \mathrm{m}$ & & & & & 0.79 & 0.03 & & & 0.85 & 0.06 & 0.82 & 0.04 & 0.83 & 0.04 & 12 Ref \\
\hline $\mathrm{MgO}, \% \mathrm{~m} / \mathrm{m}$ & & & & & 22.6 & 0.2 & & & 22.3 & 0.4 & 22.4 & 0.2 & 22.4 & 0.2 & 12 Ref \\
\hline $\mathrm{Al} 2 \mathrm{O} 3, \% \mathrm{~m} / \mathrm{m}$ & & & & & 11.1 & 0.3 & & & 11.0 & 0.2 & 11.0 & 0.1 & 11.0 & 0.2 & 11 Ref \\
\hline $\mathrm{SiO} 2, \% \mathrm{~m} / \mathrm{m}$ & & & & & 46.1 & 1.0 & & & 45.4 & 0.4 & 45.7 & 0.5 & 45.5 & 0.4 & 12 Ref \\
\hline $\mathrm{P} 2 \mathrm{O} 5, \% \mathrm{~m} / \mathrm{m}$ & & & & & 0.037 & 0.018 & & & 0.035 & 0.005 & 0.036 & 0.002 & 0.036 & 0.012 & 5 Inf \\
\hline $\mathrm{S}, \mu \mathrm{g} / \mathrm{g}$ & & & & & & & & & 1.8 & & 1.8 & & 1.8 & & $1 \mathrm{Inf}$ \\
\hline $\mathrm{Cl}, \mu \mathrm{g} / \mathrm{g}$ & & & & & & & & & 6.2 & & 6.2 & & 6.2 & & 1 Inf \\
\hline $\mathrm{K} 2 \mathrm{O}, \% \mathrm{~m} / \mathrm{m}$ & 0.0314 & & & & 0.0323 & 0.0053 & & & 0.0300 & 0.0053 & 0.0312 & 0.0012 & 0.0308 & 0.0034 & 13 Ref \\
\hline $\mathrm{CaO}, \% \mathrm{~m} / \mathrm{m}$ & & & & & 8.38 & 0.38 & & & 8.48 & 0.10 & 8.43 & 0.07 & 8.45 & 0.12 & 14 Ref \\
\hline $\mathrm{Sc}, \mu \mathrm{g} / \mathrm{g}$ & & & 34.0 & & 34.9 & 1.2 & 37.2 & 1.6 & & & 35.4 & 1.7 & 36.5 & 1.2 & 11 Ref \\
\hline $\mathrm{TiO} 2, \% \mathrm{~m} / \mathrm{m}$ & & & & & 0.309 & 0.055 & 0.326 & 0.024 & 0.295 & 0.016 & 0.310 & 0.016 & 0.306 & 0.013 & 21 Ref \\
\hline $\mathrm{V}, \mu \mathrm{g} / \mathrm{g}$ & & & & & 188 & & 219 & 25 & 190 & & 199 & 18 & 214 & 17 & 11 Ref \\
\hline $\mathrm{Cr}, \mu \mathrm{g} / \mathrm{g}$ & & & & & 2425 & 87 & 2640 & 207 & 2510 & 149 & 2525 & 108 & 2528 & 183 & 17 Ref \\
\hline $\mathrm{MnO}, \% \mathrm{~m} / \mathrm{m}$ & & & & & 0.149 & 0.006 & 0.147 & 0.014 & 0.160 & 0.015 & 0.152 & 0.007 & 0.154 & 0.007 & 18 Ref \\
\hline $\mathrm{FeO} \mathrm{T}, \% \mathrm{~m} / \mathrm{m}$ & & & & & 10.0 & 0.4 & & & 10.2 & 0.2 & 10.1 & 0.1 & 10.1 & 0.1 & 14 Ref \\
\hline $\mathrm{Co}, \mu \mathrm{g} / \mathrm{g}$ & & & 93.0 & & 86.6 & 6.8 & 94.5 & 10.7 & & & 91.4 & 4.2 & 92.7 & 5.7 & 14 Ref \\
\hline $\mathrm{Ni}, \mu \mathrm{g} / \mathrm{g}$ & & & & & 1168 & 39 & 1194 & 122 & 1210 & & 1190 & 21 & 1187 & 58 & 13 Ref \\
\hline $\mathrm{Cu}, \mu \mathrm{g} / \mathrm{g}$ & & & 190 & & 200 & & 208 & 20 & & & 199 & 9 & 205 & 21 & 8 Ref \\
\hline $\mathrm{Zn}, \mu \mathrm{g} / \mathrm{g}$ & & & 69.0 & & 76.3 & 11.4 & 79.9 & 16.2 & & & 75.1 & 5.6 & 76.8 & 12.5 & 7 Ref \\
\hline $\mathrm{Ga}, \mu \mathrm{g} / \mathrm{g}$ & & & 11.0 & & 10.7 & 0.1 & 10.1 & 1.3 & & & 10.6 & 0.4 & 10.4 & 0.9 & 8 Ref \\
\hline $\mathrm{Ge}, \mu \mathrm{g} / \mathrm{g}$ & & & & & & & 0.68 & 0.12 & & & 0.68 & & 0.68 & & $3 \mathrm{Inf}$ \\
\hline As, $\mu \mathrm{g} / \mathrm{g}$ & & & & & & & 0.16 & 0.01 & & & 0.16 & & 0.16 & & $2 \mathrm{Inf}$ \\
\hline $\mathrm{Se}, \mu \mathrm{g} / \mathrm{g}$ & & & & & & & $<0.03$ & & & & $<0.03$ & & $<0.03$ & & 1 Inf \\
\hline $\mathrm{Br}, \mathrm{r}$ & & & & & $<0.2$ & & & & & & $<0.2$ & & $<0.2$ & & 1 Inf \\
\hline $\mathrm{g} / \mathrm{g}$ & 2.08 & & 2.10 & & 2.12 & 0.12 & 2.10 & 0.22 & & & 2.10 & 0.02 & 2.10 & 0.10 & 17 Ref \\
\hline $\mathrm{Sr}, \mu \mathrm{g} / \mathrm{g}$ & 18.0 & & 15.0 & 0.1 & & & 15.1 & 1.3 & 15.4 & & 15.9 & 1.5 & 15.3 & 0.62 & 22 Ref \\
\hline $\mathrm{Y}, \mu \mathrm{g} / \mathrm{g}$ & & & 12.8 & & 10.6 & & 13.0 & 1.0 & 13.4 & & 12.5 & 1.3 & 12.9 & 0.5 & 20 Ref \\
\hline $\mathrm{Zr}, \mu \mathrm{g} / \mathrm{g}$ & 10.2 & & 10.4 & 0.6 & 11.0 & & 9.7 & 0.8 & 10.5 & & 10.4 & 0.5 & 9.9 & 0.32 & 22 Ref \\
\hline $\mathrm{Nb}, \mu \mathrm{g} / \mathrm{g}$ & & & 0.086 & & 0.072 & & 0.069 & 0.026 & 0.090 & & 0.079 & 0.010 & 0.073 & 0.013 & 17 Ref \\
\hline Mo, $\mu \mathrm{g} / \mathrm{g}$ & & & 32.0 & & 31.1 & 1.3 & 29.9 & 4.0 & & & 31.0 & 1.1 & 30.5 & 2.6 & 8 Ref \\
\hline \multicolumn{16}{|l|}{$\mathrm{Rh}, \mu \mathrm{g} / \mathrm{g}$} \\
\hline & & & & & & & & & & & & & & & \\
\hline & & & & & & & 0.04 & & & & 0.04 & & 0.04 & & $1 \mathrm{Inf}$ \\
\hline & & & & & & & 0.08 & 0.01 & & & 0.08 & & 0.08 & & $2 \mathrm{Inf}$ \\
\hline In, & & & & & & & 0.09 & 0.04 & & & 0.09 & & 0.09 & & 3 Inf \\
\hline $\mathrm{Sn}, \mathrm{l}$ & & & & & 0.30 & & 0.34 & 0.09 & & & 0.32 & 0.03 & 0.34 & 0.09 & $7 \mathrm{Inf}$ \\
\hline $\mathrm{Sb}, 1$ & & & 0.06 & & 0.11 & & 0.04 & 0.02 & & & 0.07 & 0.04 & 0.06 & 0.04 & 5 Ref \\
\hline Cs, & & & 7.46 & 0.34 & 8.56 & 0.08 & 7.12 & 1.23 & 8.86 & & 8.00 & 0.84 & 7.45 & 0.63 & 16 Ref \\
\hline & 0.860 & & 0.720 & & & & 0.816 & 0.144 & 0.830 & 0.028 & 0.807 & 0.061 & 0.815 & 0.062 & 19 Ref \\
\hline $\mathrm{La}, \mu \mathrm{g} / \mathrm{g}$ & 0.0769 & & 0.0930 & & 0.0795 & 0.0064 & 0.0843 & 0.0060 & 0.0885 & 0.0021 & 0.0844 & 0.0065 & 0.0842 & 0.0029 & 21 Ref \\
\hline $\mathrm{Ce}, \mu \mathrm{g} / \mathrm{g}$ & 0.375 & & 0.358 & & & & 0.397 & 0.043 & 0.395 & 0.013 & 0.381 & 0.018 & 0.393 & 0.018 & 21 Ref \\
\hline $\mathrm{Pr}, \mu \mathrm{g} / \mathrm{g}$ & & & 0.093 & 0.011 & 0.110 & & 0.087 & 0.006 & 0.091 & & 0.095 & 0.010 & 0.089 & 0.004 & 17 Ref \\
\hline $\mathrm{Nd}, \mu \mathrm{g} / \mathrm{g}$ & 0.685 & & 0.695 & 0.050 & 0.762 & & 0.679 & 0.034 & 0.724 & 0.012 & 0.709 & 0.034 & 0.689 & 0.0172 & 21 Ref \\
\hline $\mathrm{Sm}$, & 0.509 & & 0.467 & 0.000 & 0.536 & 0.036 & 0.504 & 0.032 & 0.531 & 0.035 & 0.509 & 0.027 & 0.508 & 0.015 & 22 Ref \\
\hline $\mathrm{Eu}, \mathrm{r}$ & 0.254 & & 0.258 & 0.018 & 0.245 & 0.005 & 0.253 & 0.016 & 0.283 & 0.006 & 0.259 & 0.014 & 0.255 & 0.0072 & 24 Ref \\
\hline $\mathrm{Gd}, \mu \mathrm{g} / \mathrm{g}$ & 1.25 & & 1.21 & 0.01 & 1.30 & & 1.16 & 0.09 & 1.31 & 0.05 & 1.24 & 0.06 & 1.19 & 0.042 & 20 Ref \\
\hline $\mathrm{Tb}, \mu \mathrm{g} / \mathrm{g}$ & & & 0.286 & 0.020 & 0.273 & 0.023 & 0.262 & 0.020 & 0.290 & & 0.278 & 0.013 & 0.269 & 0.011 & 17 Ref \\
\hline Dy, $\mu \mathrm{g} / \mathrm{g}$ & 2.20 & & 2.13 & 0.11 & 2.09 & 0.11 & 2.16 & 0.14 & 2.22 & 0.18 & 2.16 & 0.05 & 2.15 & 0.06 & 21 Ref \\
\hline Ho, $\mu \mathrm{g} / \mathrm{g}$ & & & 0.510 & 0.029 & 0.555 & 0.023 & 0.494 & 0.035 & 0.518 & & 0.519 & 0.026 & 0.507 & 0.019 & 18 Ref \\
\hline $\mathrm{Er}, \mu \mathrm{g} / \mathrm{g}$ & 1.68 & & 1.62 & 0.11 & 1.77 & & 1.53 & 0.10 & 1.50 & 0.12 & 1.62 & 0.11 & 1.56 & 0.05 & 20 Ref \\
\hline $\mathrm{Tm}, \mu \mathrm{g} / \mathrm{g}$ & & & 0.240 & 0.015 & & & 0.233 & 0.017 & 0.240 & & 0.237 & 0.004 & 0.234 & 0.009 & 14 Ref \\
\hline $\mathrm{Yb}, \mu \mathrm{g} / \mathrm{g}$ & 1.67 & & 1.56 & 0.06 & 1.64 & 0.08 & 1.60 & 0.09 & 1.62 & 0.12 & 1.62 & 0.044 & 1.61 & 0.042 & 22 Ref \\
\hline $\mathrm{Lu}, \mu \mathrm{g} / \mathrm{g}$ & 0.254 & & 0.241 & 0.013 & 0.223 & 0.029 & 0.237 & 0.019 & 0.250 & & 0.241 & 0.012 & 0.237 & 0.009 & 21 Ref \\
\hline
\end{tabular}


Table 13e. (continued)

\begin{tabular}{|c|c|c|c|c|c|c|c|c|c|c|c|c|c|}
\hline & ID & ICPMS & \multicolumn{2}{|c|}{ BULK T. } & \multicolumn{2}{|c|}{ LA-ICPMS } & \multicolumn{2}{|c|}{ MICRO T. } & \multicolumn{2}{|c|}{$\begin{array}{c}\text { All } \\
\text { Techniques }\end{array}$} & \multicolumn{3}{|c|}{ Preferred Value } \\
\hline & Mean SD & Mean SD & Mean & $\mathrm{SD}$ & Mean & $\mathrm{SD}$ & Mean & SD & Mean & $\mathrm{SD}$ & Ov. Mean & $\mathrm{U}$ & $\mathrm{n}$ \\
\hline Hf, $\mu \mathrm{g} / \mathrm{g}$ & $\mathbf{0 . 3 5 2} 0.012$ & $\mathbf{0 . 3 6 0} 0.057$ & 0.420 & 0.028 & 0.349 & 0.035 & 0.330 & & 0.362 & 0.034 & 0.357 & 0.018 & $20 \mathrm{Ref}$ \\
\hline $\mathrm{Ta}, \mu \mathrm{g} / \mathrm{g}$ & $\mathbf{0 . 0 3 7} 0.001$ & 0.040 & 0.033 & 0.004 & 0.030 & 0.003 & & & 0.035 & 0.004 & 0.031 & 0.002 & 18 Ref \\
\hline $\mathrm{W}, \mu \mathrm{g} / \mathrm{g}$ & & & 26.0 & & 25.3 & 4.8 & & & 25.6 & 0.5 & 25.4 & 3.4 & $8 \mathrm{Inf}$ \\
\hline $\mathrm{Re}, \mu \mathrm{g} / \mathrm{g}$ & & & & & 0.0009 & 0.0001 & & & 0.0009 & & 0.0009 & & $3 \mathrm{Inf}$ \\
\hline Os, $\mu \mathrm{g} / \mathrm{g}$ & & & $<0.2$ & & & & & & $<0.2$ & & $<0.2$ & & $1 \operatorname{Inf}$ \\
\hline $\mathrm{Ir}, \mu \mathrm{g} / \mathrm{g}$ & & & 1.28 & 0.03 & & & & & 1.28 & & 1.28 & & $2 \operatorname{Inf}$ \\
\hline $\mathrm{Pt}, \mu \mathrm{g} / \mathrm{g}$ & & & 12.4 & 1.2 & 13.5 & & & & 12.9 & 0.81 & 13 & 11 & $3 \mathrm{Inf}$ \\
\hline $\mathrm{Au}, \mu \mathrm{g} / \mathrm{g}$ & & & 0.14 & 0.00 & 0.08 & 0.01 & & & 0.11 & 0.04 & 0.11 & 0.09 & $4 \operatorname{Inf}$ \\
\hline $\mathrm{Hg}, \mu \mathrm{g} / \mathrm{g}$ & & & $<0.4$ & & & & & & $<0.4$ & & $<0.4$ & & $1 \mathrm{Inf}$ \\
\hline $\mathrm{Tl}, \mu \mathrm{g} / \mathrm{g}$ & & & & & 0.001 & & & & 0.001 & & 0.001 & & $1 \mathrm{Inf}$ \\
\hline $\mathrm{Pb}, \mu \mathrm{g} / \mathrm{g}$ & & 19.0 & & & 19.5 & 2.8 & & & 19.3 & 0.4 & 19.5 & & 12 Ref \\
\hline $\mathrm{Bi}, \mu \mathrm{g} / \mathrm{g}$ & & & 0.008 & & 0.007 & 0.001 & & & 0.007 & 0.001 & 0.007 & 0.003 & $3 \mathrm{Inf}$ \\
\hline $\mathrm{Th}, \mu \mathrm{g} / \mathrm{g}$ & & 0.020 & 0.016 & & 0.006 & 0.003 & 0.020 & & 0.016 & 0.006 & 0.009 & 0.003 & $15 \mathrm{Ref}$ \\
\hline $\mathrm{U}, \mu \mathrm{g} / \mathrm{g}$ & & $\mathbf{0 . 0 4 6} 0.006$ & 0.044 & 0.005 & 0.049 & 0.010 & & & 0.046 & 0.003 & 0.048 & 0.005 & 17 Ref \\
\hline
\end{tabular}

${ }^{a}$ All techniques mean: average of 1-5 techn. groups means, Ov. (overall) mean: unweighted mean of all results, Ref: reference value, Inf: information value, SD: standard deviation, U: uncertainty at 95\% confidence level, n: number of analyses. BULK T.: XRF, SSMS, MIC-SSMS, MS, INAA, ICP-AES; MICRO T.: EPMA, SIMS, LIMS, SR-XRF, PIXE.

Table 13f. Summary of Composition Data for BM90/21-Ga

\begin{tabular}{|c|c|c|c|c|c|c|c|c|c|c|c|c|c|c|}
\hline & \multicolumn{2}{|l|}{ ID } & \multirow{2}{*}{$\frac{\text { ICPMS }}{\text { Mean SD }}$} & \multicolumn{2}{|c|}{ BULK T. } & \multicolumn{2}{|c|}{ LA-ICPMS } & \multicolumn{2}{|c|}{ MICRO T. } & \multicolumn{2}{|c|}{ All Techniques } & \multicolumn{3}{|c|}{ Preferred Value } \\
\hline & Mean & SD & & Mean & SD & Mean & SD & Mean & SD & Mean & SD & Ov. Mean & $\mathrm{U}$ & $\mathrm{n}$ \\
\hline $\mathrm{H} 2 \mathrm{O}, \% \mathrm{~m} / \mathrm{m}$ & & & & & & & & 0.014 & & 0.014 & & 0.014 & & $1 \mathrm{Inf}$ \\
\hline $\mathrm{Li}, \mu \mathrm{g} / \mathrm{g}$ & & & & & & 2.6 & 0.4 & 1.4 & & 2.0 & 0.9 & 2.2 & 1.7 & 3 Inf \\
\hline $\mathrm{Be}, \mu \mathrm{g} / \mathrm{g}$ & & & & & & & & 0.01 & & 0.01 & & 0.01 & & $1 \mathrm{Inf}$ \\
\hline $\mathrm{B}, \mu \mathrm{g} / \mathrm{g}$ & & & & & & 5.6 & & 2.8 & & 4.2 & 2.0 & 4.2 & & 2 Inf \\
\hline $\mathrm{CO} 2, \mu \mathrm{g} / \mathrm{g}$ & & & & & & & & 6.0 & & 6.0 & & 6.0 & & 1 Inf \\
\hline $\mathrm{O}, \% \mathrm{~m} / \mathrm{m}$ & & & & & & & & 45.8 & & 45.8 & & 45.8 & & 1 Inf \\
\hline $\mathrm{F}, \mu \mathrm{g} / \mathrm{g}$ & & & & & & & & 2.6 & & 2.6 & & 2.6 & & 1 Inf \\
\hline $\mathrm{Na} 2 \mathrm{O}, \% \mathrm{~m} / \mathrm{m}$ & & & & 0.108 & 0.021 & & & 0.120 & 0.013 & 0.114 & 0.009 & 0.115 & 0.014 & 8 Ref \\
\hline $\mathrm{MgO}, \% \mathrm{~m} / \mathrm{m}$ & & & & 34.8 & & & & 34.2 & 0.4 & 34.5 & 0.4 & 34.3 & 0.5 & 7 Inf \\
\hline $\mathrm{Al} 2 \mathrm{O} 3, \% \mathrm{~m} / \mathrm{m}$ & & & & 2.44 & & & & 2.31 & 0.04 & 2.37 & 0.09 & 2.33 & 0.05 & 7 Inf \\
\hline $\mathrm{SiO} 2, \% \mathrm{~m} / \mathrm{m}$ & & & & 53.6 & & & & 53.1 & 0.7 & 53.3 & 0.4 & 53.1 & 0.5 & 7 Inf \\
\hline $\mathrm{P} 2 \mathrm{O} 5, \% \mathrm{~m} / \mathrm{m}$ & & & & $<0.0004$ & & & & & & $<0.0004$ & & $<0.0004$ & & 1 Inf \\
\hline $\mathrm{S}$ & & & & & & & & 1.2 & & 1.2 & & 1.2 & & 1 Inf \\
\hline $\mathrm{Cl}, \mu \mathrm{g} / \mathrm{g}$ & & & & & & & & 0.7 & & 0.7 & & 0.7 & & $1 \mathrm{Inf}$ \\
\hline $\mathrm{K} 2 \mathrm{O}, \% \mathrm{~m} / \mathrm{m}$ & 0.00375 & & & 0.00370 & & & & & & 0.00372 & & 0.00372 & 0.00025 & 2 Inf \\
\hline $\mathrm{CaO}, \% \mathrm{~m} / \mathrm{m}$ & & & & 2.12 & & & & 2.10 & 0.03 & 2.11 & 0.02 & 2.10 & 0.02 & $7 \mathrm{Inf}$ \\
\hline $\mathrm{Sc}, \mu \mathrm{g} / \mathrm{g}$ & & & & 11.3 & 0.0 & 14.3 & 1.3 & & & 12.8 & 2.1 & 13.3 & 2.3 & 6 Inf \\
\hline $\mathrm{TiO} 2, \% \mathrm{~m} / \mathrm{m}$ & & & & 0.067 & & 0.067 & 0.005 & 0.057 & 0.010 & 0.064 & 0.006 & 0.062 & 0.007 & 10 Ref \\
\hline $\mathrm{V}, \mu \mathrm{g} / \mathrm{g}$ & & & & 37 & & 66 & 6 & & & 52 & 21 & 61 & 15 & 6 Inf \\
\hline $\mathrm{Cr}$, & & & & 2073 & 64 & 2367 & 115 & 2127 & 225 & 2189 & 156 & 2190 & 210 & 9 Ref \\
\hline$\% \mathrm{~m} / \mathrm{m}$ & & & & 0.106 & 0.005 & 0.134 & & 0.107 & 0.005 & 0.116 & 0.016 & 0.109 & 0.009 & 9 Ref \\
\hline $\mathrm{FeO} \mathrm{T}, \% \mathrm{~m} / \mathrm{m}$ & & & & 6.77 & 0.19 & & & 6.82 & 0.17 & 6.79 & 0.04 & 6.80 & 0.14 & 9 Ref \\
\hline $\mathrm{Co}, \mu \mathrm{g} / \mathrm{g}$ & & & & 88.5 & 3.9 & 103.0 & 6.2 & & & 95.8 & 10.2 & 97.6 & 7.6 & 8 Ref \\
\hline $\mathrm{Ni}, \mu \mathrm{g} / \mathrm{g}$ & & & & 1883 & 119 & 1902 & 178 & & & 1893 & 13 & 1900 & 120 & 9 Ref \\
\hline $\mathrm{Cu}, \mu \mathrm{g} / \mathrm{g}$ & & & & 36.0 & & 38.4 & 6.0 & & & 37.2 & 1.7 & 37.9 & 7.4 & $5 \mathrm{Inf}$ \\
\hline $\mathrm{Zn}, \mu \mathrm{g} / \mathrm{g}$ & & & & 39.3 & 3.1 & 41.7 & & & & 40.5 & 1.7 & 39.9 & 5.9 & 4 Ref \\
\hline $\mathrm{Ga}, \mu \mathrm{g} / \mathrm{g}$ & & & & 2.6 & 0.6 & 2.0 & 0.3 & & & 2.3 & 0.4 & 2.3 & 1.0 & $4 \operatorname{Inf}$ \\
\hline $\mathrm{Ge}, \mu \mathrm{g} / \mathrm{g}$ & & & & & & 0.44 & 0.05 & & & 0.44 & & 0.44 & & $2 \operatorname{Inf}$ \\
\hline As, & & & & & & $<\mathbf{0 . 0 3}$ & & & & $<\mathbf{0 . 0 3}$ & & $<\mathbf{0 . 0 3}$ & & 1 Inf \\
\hline $\mathrm{Se}, \mathrm{p}$ & & & & & & $<0.009$ & & & & $<0.009$ & & $<0.009$ & & 1 Inf \\
\hline $\mathrm{Br}$ & & & & $<0.1$ & & & & & & $<0.1$ & & $<0.1$ & & $1 \mathrm{Inf}$ \\
\hline $\mathrm{g} / \mathrm{g}$ & 0.391 & & 0.450 & & & & 0.03 & & & 0.397 & 0.050 & 0.374 & 0.093 & 6 Ref \\
\hline $\mathrm{Sr}, \mu \mathrm{g} / \mathrm{g}$ & 0.800 & & 0.880 & & & 0.729 & 0.057 & 1.030 & & 0.86 & 0.13 & 0.78 & 0.08 & 11 Ref \\
\hline
\end{tabular}


Table 13f. (continued)

\begin{tabular}{|c|c|c|c|c|c|c|c|c|c|c|c|c|c|c|c|}
\hline & \multicolumn{2}{|l|}{ ID } & \multirow{2}{*}{$\frac{\text { ICPMS }}{\text { Mean SD }}$} & \multicolumn{2}{|c|}{ BULK T. } & \multicolumn{2}{|c|}{ LA-ICPMS } & \multicolumn{2}{|c|}{ MICRO T. } & \multicolumn{2}{|c|}{ All Techniques } & \multicolumn{4}{|c|}{ Preferred Value } \\
\hline & Mean & SD & & Mean & SD & Mean & SD & Mean & $\mathrm{SD}$ & Mean & SD & Ov. Mean & $\mathrm{U}$ & $\mathrm{n}$ & \\
\hline $\mathrm{Y}, \mu \mathrm{g} / \mathrm{g}$ & & & 2.04 & 1.44 & & 2.30 & 0.19 & 2.10 & & 1.97 & 0.37 & 2.18 & 0.20 & 11 & Ref \\
\hline $\mathrm{Zr}, \mu \mathrm{g} / \mathrm{g}$ & & & 20.4 & 19.3 & & 20.1 & 2.0 & 19.5 & & 19.8 & 0.5 & 20.0 & 0.9 & 11 & Ref \\
\hline $\mathrm{Nb}, \mu \mathrm{g} / \mathrm{g}$ & & & & 0.039 & & 0.037 & 0.005 & 0.050 & & 0.042 & 0.007 & 0.039 & 0.005 & 9 & Ref \\
\hline Mo, $\mu \mathrm{g} / \mathrm{g}$ & & & & 16.8 & 0.4 & 19.6 & 5.1 & & & 18 & 2 & 19 & 4 & 6 & Inf \\
\hline $\mathrm{Rh}, \mu \mathrm{g} / \mathrm{g}$ & & & & & & & & & & & & & & & \\
\hline $\mathrm{Pd}, \mu \mathrm{g} / \mathrm{g}$ & & & & $<6$ & & & & & & $<6$ & & $<6$ & & 1 & Inf \\
\hline $\mathrm{Ag}, \mu \mathrm{g} / \mathrm{g}$ & & & & $<0.3$ & & & & & & $<0.3$ & & $<0.3$ & & 1 & Inf \\
\hline $\mathrm{Cd}, \mu \mathrm{g} / \mathrm{g}$ & & & & & & 0.1 & 0.1 & & & 0.1 & & 0.1 & & 2 & Inf \\
\hline $\mathrm{In}, \mu \mathrm{g} / \mathrm{g}$ & & & & 0.18 & & 0.19 & 0.05 & & & 0.19 & 0.009 & 0.19 & 0.06 & 4 & Inf \\
\hline $\mathrm{Sn}, \mu \mathrm{g} / \mathrm{g}$ & & & & & & 0.4 & 0.4 & & & 0.4 & & 0.4 & & 3 & Inf \\
\hline $\mathrm{Sb}, \mu \mathrm{g} / \mathrm{g}$ & & & & 0.052 & 0.026 & 0.022 & 0.011 & & & 0.037 & 0.021 & 0.037 & 0.038 & 4 & Inf \\
\hline $\mathrm{Cs}, \mu \mathrm{g} / \mathrm{g}$ & & & 1.10 & 1.31 & 0.08 & 0.94 & 0.04 & & & 1.11 & 0.18 & 1.07 & 0.17 & 7 & Ref \\
\hline $\mathrm{Ba}, \mu \mathrm{g} / \mathrm{g}$ & 0.580 & & & & & 0.528 & 0.056 & 0.520 & & 0.543 & 0.033 & 0.533 & 0.032 & 10 & Ref \\
\hline $\mathrm{La}, \mu \mathrm{g} / \mathrm{g}$ & 0.211 & & 0.205 & 0.232 & 0.013 & 0.219 & 0.011 & 0.260 & & 0.225 & 0.022 & 0.223 & 0.009 & 14 & Ref \\
\hline $\mathrm{Ce}, \mu \mathrm{g} / \mathrm{g}$ & 0.422 & & 0.403 & 0.510 & & 0.480 & 0.041 & 0.460 & & 0.455 & 0.043 & 0.471 & 0.033 & 13 & Ref \\
\hline $\operatorname{Pr}, \mu \mathrm{g} / \mathrm{g}$ & & & 0.066 & 0.097 & & 0.072 & 0.004 & & & 0.078 & 0.016 & 0.075 & 0.009 & 8 & Ref \\
\hline $\mathrm{Nd}, \mu \mathrm{g} / \mathrm{g}$ & 0.355 & & 0.332 & 0.408 & & 0.365 & 0.024 & 0.390 & & 0.370 & 0.030 & 0.367 & 0.020 & 11 & Ref \\
\hline $\mathrm{Sm}, \mu \mathrm{g} / \mathrm{g}$ & 0.142 & & 0.133 & 0.155 & 0.023 & 0.146 & 0.007 & 0.150 & & 0.145 & 0.008 & 0.147 & 0.009 & 13 & Ref \\
\hline $\mathrm{Eu}, \mu \mathrm{g} / \mathrm{g}$ & 0.052 & & 0.049 & 0.054 & 0.008 & 0.052 & 0.006 & 0.060 & & 0.054 & 0.004 & 0.053 & 0.002 & 14 & Ref \\
\hline $\mathrm{Gd}, \mu \mathrm{g} / \mathrm{g}$ & 0.243 & & 0.228 & 0.320 & & 0.249 & 0.032 & & & 0.260 & 0.041 & 0.253 & 0.023 & 10 & Ref \\
\hline $\mathrm{Tb}, \mu \mathrm{g} / \mathrm{g}$ & & & 0.044 & 0.056 & 0.008 & 0.050 & 0.003 & & & 0.050 & 0.006 & 0.051 & 0.005 & 7 & Ref \\
\hline Dy, $\mu \mathrm{g} / \mathrm{g}$ & 0.352 & & 0.333 & 0.349 & 0.016 & 0.373 & 0.021 & 0.350 & & 0.352 & 0.014 & 0.361 & 0.013 & 13 & Ref \\
\hline Ho, $\mu \mathrm{g} / \mathrm{g}$ & & & 0.075 & 0.085 & 0.012 & 0.084 & 0.006 & & & 0.081 & 0.005 & 0.083 & 0.007 & 8 & Ref \\
\hline $\mathrm{Er}, \mu \mathrm{g} / \mathrm{g}$ & 0.256 & & 0.234 & 0.302 & & 0.269 & 0.016 & 0.230 & & 0.258 & 0.029 & 0.264 & 0.016 & 11 & Ref \\
\hline $\mathrm{Tm}, \mu \mathrm{g} / \mathrm{g}$ & & & 0.036 & & & 0.043 & 0.002 & & & 0.039 & 0.005 & 0.041 & 0.006 & 5 & Inf \\
\hline $\mathrm{Yb}, \mu \mathrm{g} / \mathrm{g}$ & 0.275 & & 0.259 & 0.273 & 0.008 & 0.291 & 0.019 & 0.250 & & 0.270 & 0.016 & 0.280 & 0.013 & 13 & Ref \\
\hline $\mathrm{Lu}, \mu \mathrm{g} / \mathrm{g}$ & 0.044 & & 0.040 & 0.040 & 0.003 & 0.048 & 0.003 & & & 0.043 & 0.004 & 0.045 & 0.002 & 12 & Ref \\
\hline Hf, $\mu \mathrm{g} / \mathrm{g}$ & & & 0.490 & 0.507 & 0.010 & 0.528 & 0.047 & & & 0.508 & 0.019 & 0.520 & 0.025 & 10 & Ref \\
\hline $\mathrm{Ta}, \mu \mathrm{g} / \mathrm{g}$ & & & & & & 0.0031 & 0.0008 & & & 0.0031 & & 0.0031 & 0.0009 & 6 & Inf \\
\hline $\mathrm{W}, \mu \mathrm{g} / \mathrm{g}$ & & & & 0.48 & 0.03 & 0.50 & 0.15 & & & 0.49 & 0.013 & 0.49 & 0.13 & 6 & Inf \\
\hline $\mathrm{Re}, \mu \mathrm{g} / \mathrm{g}$ & & & & & & 0.0008 & & & & 0.0008 & & 0.0008 & & 1 & Inf \\
\hline Os, $\mu \mathrm{g} / \mathrm{g}$ & & & & $<0.3$ & & & & & & $<0.3$ & & $<0.3$ & & 1 & Inf \\
\hline $\mathrm{Ir}, \mu \mathrm{g} / \mathrm{g}$ & & & & 0.065 & 0.000 & & & & & 0.065 & & 0.065 & & 2 & Inf \\
\hline $\mathrm{Pt}, \mu \mathrm{g} / \mathrm{g}$ & & & & 20 & 1 & & & & & 20 & & 20 & & 2 & Inf \\
\hline $\mathrm{Au}, \mu \mathrm{g} / \mathrm{g}$ & & & & 0.064 & 0.003 & & & & & 0.064 & & 0.064 & & 2 & Inf \\
\hline $\mathrm{Hg}, \mu \mathrm{g} / \mathrm{g}$ & & & & $<0.3$ & & & & & & $<0.3$ & & $<0.3$ & & 1 & Inf \\
\hline $\mathrm{Tl}, \mu \mathrm{g} / \mathrm{g}$ & & & & & & 0.006 & & & & 0.006 & & 0.006 & & 1 & Inf \\
\hline $\mathrm{Pb}, \mu \mathrm{g} / \mathrm{g}$ & & & & 0.79 & & 0.54 & 0.14 & & & 0.66 & 0.18 & 0.57 & 0.17 & 7 & Inf \\
\hline $\mathrm{Bi}, \mu \mathrm{g} / \mathrm{g}$ & & & & 0.0015 & & & & & & 0.0015 & & 0.0015 & & 1 & Inf \\
\hline $\mathrm{Th}, \mu \mathrm{g} / \mathrm{g}$ & & & 0.049 & 0.038 & & 0.056 & 0.005 & 0.060 & & 0.051 & 0.010 & 0.054 & 0.004 & 11 & Ref \\
\hline $\mathrm{U}, \mu \mathrm{g} / \mathrm{g}$ & & & 0.073 & 0.088 & 0.002 & 0.085 & 0.009 & & & 0.082 & 0.008 & 0.084 & 0.005 & 10 & Ref \\
\hline
\end{tabular}

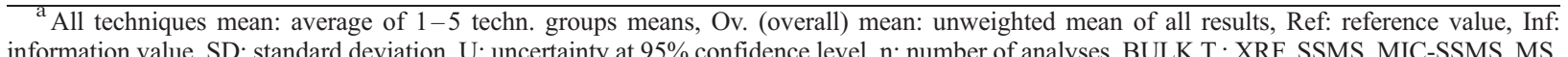
INAA, ICP-AES; MICRO T.: EPMA, SIMS, LIMS, SR-XRF, PIXE.

Concentration data were mostly calibrated with international reference materials. A special sample preparation technique was used for the application of ID to SSMS and MIC-SSMS [Jochum et al., 2000].

\subsubsection{Microanalytical Techniques}

[83] LA-ICPMS: Many trace element data were obtained by this microanalytical technique, which has become one of the most important techniques for in situ measurements of geochemical samples. Calibration of the data was mainly performed using synthetic NIST reference glasses, such as NIST SRM 612 and NIST SRM 610, and the compiled values of Pearce et al. [1997].

[84] Other microanalytical techniques (EPMA, SIMS, LIMS, SR-XRF, PIXE): The methods of this group are comparative and independent with respect to at least two of the three criteria: sample preparation, calibrants, instruments. EPMA is a 
Table 13g. Summary of Composition Data for $T 1-G^{a}$

\begin{tabular}{|c|c|c|c|c|c|c|c|c|c|c|c|c|c|c|c|c|}
\hline & \multicolumn{2}{|c|}{ ID } & \multicolumn{2}{|c|}{ ICPMS } & \multicolumn{2}{|c|}{ BULK T. } & \multicolumn{2}{|c|}{ LA-ICPMS } & \multicolumn{2}{|c|}{ MICRO T. } & \multicolumn{2}{|c|}{$\begin{array}{c}\text { All } \\
\text { Techniques }\end{array}$} & \multicolumn{4}{|c|}{ Preferred Value } \\
\hline & Mean & SD & Mean & SD & Mean & SD & Mean & SD & Mean & SD & Mean & SD & Ov. Mean & $\mathrm{U}$ & $\mathrm{n}$ & \\
\hline $\mathrm{H} 2 \mathrm{O}, \% \mathrm{~m} / \mathrm{m}$ & & & & & 0.04 & & & & 0.012 & & 0.026 & 0.02 & 0.026 & & & Inf \\
\hline $\mathrm{Li}, \mu \mathrm{g} / \mathrm{g}$ & & & 19.8 & 0.4 & & & 20.2 & 1.6 & 19.4 & 1.4 & 19.8 & 0.4 & 19.9 & 0.9 & 10 & Ref \\
\hline $\mathrm{Be}, \mu \mathrm{g} / \mathrm{g}$ & & & & & & & 1.9 & 0.3 & 2.4 & & 2.2 & 0.3 & 2.0 & 0.6 & 5 & Inf \\
\hline $\mathrm{B}, \mu \mathrm{g} / \mathrm{g}$ & & & & & & & 4.0 & 1.0 & 4.6 & & 4.3 & 0.5 & 4.1 & 1.1 & 5 & Inf \\
\hline $\mathrm{CO} 2, \mu \mathrm{g} / \mathrm{g}$ & & & & & & & & & 6.3 & & 6.3 & & 6.3 & & 1 & Inf \\
\hline $\mathrm{O}, \% \mathrm{~m} / \mathrm{m}$ & & & & & & & & & 46.4 & & 46.4 & & 46.4 & & 1 & $\operatorname{Inf}$ \\
\hline $\mathrm{F}, \mu \mathrm{g} / \mathrm{g}$ & & & & & & & & & 321 & & 321 & & 321 & & 1 & Inf \\
\hline $\mathrm{Na} 2 \mathrm{O}, \% \mathrm{~m} / \mathrm{m}$ & & & & & 3.13 & 0.08 & & & 3.13 & 0.15 & 3.13 & 0.00 & 3.13 & 0.09 & 13 & Ref \\
\hline $\mathrm{MgO}, \% \mathrm{~m} / \mathrm{m}$ & & & & & 3.83 & 0.02 & & & 3.73 & 0.07 & 3.78 & 0.06 & 3.75 & 0.04 & 13 & Ref \\
\hline $\mathrm{A} 12 \mathrm{O} 3, \% \mathrm{~m} / \mathrm{m}$ & & & & & 17.1 & 0.0 & & & 17.1 & 0.4 & 17.1 & 0.0 & 17.1 & 0.2 & 12 & Ref \\
\hline $\mathrm{SiO} 2, \% \mathrm{~m} / \mathrm{m}$ & & & & & 58.6 & 0.4 & & & 58.6 & 0.9 & 58.6 & 0.0 & 58.6 & 0.4 & 13 & Ref \\
\hline $\mathrm{P} 2 \mathrm{O} 5, \% \mathrm{~m} / \mathrm{m}$ & & & & & 0.175 & 0.008 & & & 0.166 & 0.037 & 0.170 & 0.006 & 0.168 & 0.026 & 8 & Ref \\
\hline $\mathrm{S}, \mu \mathrm{g} / \mathrm{g}$ & & & & & & & & & 2.6 & & 2.6 & & 2.6 & & 1 & Inf \\
\hline $\mathrm{Cl}, \mu \mathrm{g} / \mathrm{g}$ & & & & & & & & & 113 & 24 & 113 & & 113 & 37 & 4 & Ref \\
\hline $\mathrm{K} 2 \mathrm{O}, \% \mathrm{~m} / \mathrm{m}$ & 1.90 & & & & 1.92 & 0.06 & & & 1.99 & 0.07 & 1.94 & 0.04 & 1.96 & 0.04 & 15 & Ref \\
\hline $\mathrm{CaO}, \% \mathrm{~m} / \mathrm{m}$ & & & & & 7.16 & 0.13 & & & 7.09 & 0.15 & 7.12 & 0.05 & 7.10 & 0.09 & 14 & Ref \\
\hline Sc, $\mu \mathrm{g} / \mathrm{g}$ & & & 25.0 & & 26.0 & 0.1 & 27.1 & 2.4 & 27.6 & 0.6 & 26.4 & 1.2 & 26.9 & 1.1 & 17 & Ref \\
\hline $\mathrm{TiO} 2, \% \mathrm{~m} / \mathrm{m}$ & & & & & 0.721 & 0.001 & 0.784 & 0.035 & 0.746 & 0.027 & 0.750 & 0.032 & 0.755 & 0.017 & 20 & Ref \\
\hline $\mathrm{V}, \mu \mathrm{g} / \mathrm{g}$ & & & & & & & 190 & 16 & 190 & & 190 & 0 & 190 & 11 & 12 & Ref \\
\hline $\mathrm{Cr}, \mu \mathrm{g} / \mathrm{g}$ & & & & & 22.3 & 2.3 & 20.3 & 1.5 & 21.0 & 7.1 & 21.2 & 1.0 & 20.9 & 2.0 & 14 & Ref \\
\hline $\mathrm{MnO}, \% \mathrm{~m} / \mathrm{m}$ & & & & & 0.133 & 0.003 & 0.125 & 0.012 & 0.125 & 0.015 & 0.128 & 0.004 & 0.127 & 0.006 & 21 & Ref \\
\hline $\mathrm{FeO} \mathrm{T}, \% \mathrm{~m} / \mathrm{m}$ & & & & & 6.50 & 0.07 & & & 6.42 & 0.14 & 6.46 & 0.05 & 6.44 & 0.06 & 16 & Ref \\
\hline $\mathrm{Co}, \mu \mathrm{g} / \mathrm{g}$ & & & 19.0 & & 19.6 & 0.6 & 19.1 & 1.8 & 16.7 & 1.9 & 18.6 & 1.3 & 18.9 & 0.8 & 18 & Ref \\
\hline $\mathrm{Ni}, \mu \mathrm{g} / \mathrm{g}$ & & & 11.0 & & 8.0 & & 10.7 & 2.4 & 12.0 & & 10.4 & 1.7 & 10.6 & 1.3 & 15 & Ref \\
\hline $\mathrm{Cu}, \mu \mathrm{g} / \mathrm{g}$ & & & 22.0 & & & & 18.5 & 2.2 & 18.0 & & 19.5 & 2.2 & 18.8 & 2.0 & 10 & Ref \\
\hline $\mathrm{Zn}, \mu \mathrm{g} / \mathrm{g}$ & & & & & 83 & 15 & 69 & 12 & 68 & 2 & 73 & 9 & 74 & 10 & 11 & Ref \\
\hline $\mathrm{Ga}, \mu \mathrm{g} / \mathrm{g}$ & & & 20.0 & & 18.0 & 0.0 & 19.8 & 1.5 & 18.0 & & 18.9 & 1.1 & 19.4 & 0.9 & 12 & Ref \\
\hline Ge, $\mu \mathrm{g} / \mathrm{g}$ & & & & & & & 1.8 & 0.9 & & & 1.8 & & 1.8 & 1.5 & 4 & Inf \\
\hline As, $\mu \mathrm{g} / \mathrm{g}$ & & & & & 0.72 & 0.20 & 1.14 & 0.59 & 0.68 & & 0.85 & 0.26 & 0.96 & 0.44 & 7 & Ref \\
\hline $\mathrm{Se}, \mu \mathrm{g} / \mathrm{g}$ & & & & & & & 0.05 & & & & 0.05 & & 0.05 & & 1 & Inf \\
\hline $\mathrm{Br}$, & & & & & 0.3 & & & & & & 0.3 & & 0.3 & & 1 & Inf \\
\hline $\mathrm{Rb}$, & 70.1 & & 81.4 & 2.9 & 82.0 & 5.6 & 80.5 & 9.0 & 73.5 & 0.7 & 77.5 & 5.4 & 79.7 & 3.5 & 23 & Ref \\
\hline $\mathrm{Sr}, \mathrm{H}$ & 292 & & 291 & 8 & 293 & 4 & 283 & 16 & 275 & 17 & 287 & 8 & 284 & 6 & 26 & Ref \\
\hline $\mathrm{Y}, \mu \mathrm{g} / \mathrm{g}$ & & & 24.3 & 0.2 & 21.9 & & 24.1 & 1.8 & 23.4 & 2.7 & 23.4 & 1.1 & 23.9 & 0.8 & 25 & Ref \\
\hline $\mathrm{Zr}, \mu \mathrm{g} / \mathrm{g}$ & 154 & & 153 & 7 & 149 & & 141 & 12 & 146 & 13 & 149 & 6 & 144 & 4 & 28 & Ref \\
\hline $\mathrm{Nb}, \mu \mathrm{g} / \mathrm{g}$ & & & 8.68 & 0.11 & 11.6 & & 8.92 & 0.53 & 7.77 & 1.56 & 9.24 & 1.65 & 8.87 & 0.43 & 24 & Ref \\
\hline Mo, $\mu \mathrm{g} / \mathrm{g}$ & & & 5.6 & & 5.4 & 1.9 & 3.6 & 2.5 & & & 4.8 & 1.1 & 4.2 & 1.8 & 9 & Ref \\
\hline \multicolumn{17}{|l|}{$\mathrm{Rh}, \mu \mathrm{g} / \mathrm{g}^{*}$} \\
\hline \multicolumn{17}{|l|}{$\mathrm{Pd}, \mu \mathrm{g} / \mathrm{g}^{*}$} \\
\hline $\mathrm{Ag}, \mu \mathrm{g} / \mathrm{g}^{*}$ & & & & & & & 0.1 & 0.1 & & & 0.1 & & 0.1 & & 2 & \\
\hline $\mathrm{Cd}, \mu$ & & & & & & & 0.2 & 0.2 & & & 0.2 & & 0.2 & & 4 & Inf \\
\hline $\mathrm{In}, \mu \mathrm{g} / \mathrm{g}$ & & & & & & & 0.3 & 0.2 & & & 0.3 & & 0.3 & 0.4 & 3 & Inf \\
\hline $\mathrm{Sn}, \mu \mathrm{g} / \mathrm{g}$ & & & 3.6 & & & & 1.8 & 0.6 & 1.4 & & 2.3 & 1.2 & 2 & 0.5 & 11 & Ref \\
\hline $\mathrm{Sb}, \mu \mathrm{g} / \mathrm{g}$ & & & 0.29 & & 0.27 & 0.00 & 0.23 & 0.08 & 0.27 & & 0.26 & 0.03 & 0.25 & 0.05 & 8 & Ref \\
\hline $\mathrm{Cs}, \mu \mathrm{g} / \mathrm{g}$ & & & 2.80 & 0.08 & 3.21 & 0.30 & 2.58 & 0.39 & 2.80 & & 2.85 & 0.26 & 2.69 & 0.19 & 20 & Ref \\
\hline $\mathrm{Ba}, \mu \mathrm{g} / \mathrm{g}$ & 391 & & 396 & 25 & 413 & 18 & 393 & 23 & 361 & 33 & 391 & 19 & 388 & 12 & 27 & Ref \\
\hline $\mathrm{La}, \mu \mathrm{g} / \mathrm{g}$ & 70.4 & & 69.6 & 2.0 & 69.3 & 6.7 & 72.1 & 4.7 & 66.1 & 10.7 & 69.5 & 2.2 & 70.4 & 2.4 & - 29 & Ref \\
\hline $\mathrm{Ce}, \mu \mathrm{g} / \mathrm{g}$ & 126 & & 121 & 6 & 133 & 4 & 129 & 6 & 113 & 19 & 124 & 8 & 127 & 4 & 27 & Ref \\
\hline $\mathrm{Pr}, \mu \mathrm{g} / \mathrm{g}$ & & & 12.6 & 0.5 & 12.6 & & 12.5 & 0.8 & 10.4 & & 12.0 & 1.1 & 12.4 & 0.4 & - 21 & Ref \\
\hline $\mathrm{Nd}, \mu \mathrm{g} / \mathrm{g}$ & 42.5 & & 40.8 & 2.2 & 42.6 & 1.9 & 42.0 & 2.5 & 38.1 & 4.1 & 41.2 & 1.9 & 41.4 & 1.2 & 30 & Ref \\
\hline $\mathrm{Sm}, \mu \mathrm{g} / \mathrm{g}$ & 6.75 & & 6.55 & 0.39 & 6.72 & 0.27 & 6.58 & 0.33 & 6.17 & 0.52 & 6.55 & 0.23 & 6.57 & 0.14 & 27 & Ref \\
\hline $\mathrm{Eu}, \mu \mathrm{g} / \mathrm{g}$ & 1.23 & & 1.23 & 0.15 & 1.27 & 0.09 & 1.20 & 0.07 & 1.10 & 0.03 & 1.20 & 0.06 & 1.21 & 0.04 & 28 & Ref \\
\hline $\mathrm{Gd}, \mu \mathrm{g} / \mathrm{g}$ & 5.28 & & 5.29 & 0.18 & 5.20 & & 5.32 & 0.67 & & & 5.27 & 0.05 & 5.31 & 0.29 & 21 & Ref \\
\hline $\mathrm{Tb}, \mu \mathrm{g} / \mathrm{g}$ & & & 0.807 & 0.081 & 0.855 & 0.039 & 0.740 & 0.044 & 0.848 & 0.011 & 0.813 & 0.05 & 0.773 & 0.029 & 23 & Ref \\
\hline Dy, $\mu \mathrm{g} / \mathrm{g}$ & 4.62 & & 4.45 & 0.22 & 4.72 & 0.03 & 4.49 & 0.30 & 4.39 & 0.12 & 4.53 & 0.13 & 4.50 & 0.12 & 25 & Ref \\
\hline $\mathrm{Ho}, \mu \mathrm{g} / \mathrm{g}$ & & & 0.890 & 0.044 & 0.843 & 0.059 & 0.867 & 0.067 & 0.720 & & 0.830 & 0.076 & 0.860 & 0.031 & 22 & Ref \\
\hline $\mathrm{Er}, \mu \mathrm{g} / \mathrm{g}$ & 2.61 & & 2.56 & 0.22 & 2.28 & 0.16 & 2.51 & 0.15 & 2.42 & 0.16 & 2.47 & 0.13 & 2.49 & 0.08 & 23 & Ref \\
\hline $\mathrm{Tm}, \mu \mathrm{g} / \mathrm{g}$ & & & 0.364 & 0.015 & & & 0.352 & 0.032 & & & 0.358 & 0.008 & 0.354 & 0.015 & 18 & Ref \\
\hline $\mathrm{Yb}, \mu \mathrm{g} / \mathrm{g}$ & 2.44 & & 2.35 & 0.06 & 2.41 & 0.15 & 2.39 & 0.24 & 2.21 & 0.30 & 2.36 & 0.09 & 2.38 & 0.08 & 27 & Ref \\
\hline $\mathrm{Lu}, \mu \mathrm{g} / \mathrm{g}$ & 0.361 & & 0.359 & 0.010 & 0.356 & 0.038 & 0.353 & 0.035 & 0.350 & & 0.356 & 0.004 & 0.354 & 0.012 & 26 & Ref \\
\hline
\end{tabular}


Table 13g. (continued)

\begin{tabular}{|c|c|c|c|c|c|c|c|c|c|c|c|c|c|c|c|c|}
\hline & \multicolumn{2}{|c|}{ ID } & \multicolumn{2}{|c|}{ ICPMS } & \multicolumn{2}{|c|}{ BULK T. } & \multicolumn{2}{|c|}{ LA-ICPMS } & \multicolumn{2}{|c|}{ MICRO T. } & \multicolumn{2}{|c|}{$\begin{array}{c}\text { All } \\
\text { Techniques }\end{array}$} & \multicolumn{4}{|c|}{ Preferred Value } \\
\hline & Mean & SD & Mean & SD & Mean & SD & Mean & SD & Mean & $\mathrm{SD}$ & Mean & SD & Ov. Mean & $\mathrm{U}$ & $\mathrm{n}$ & \\
\hline $\mathrm{Hf}, \mu \mathrm{g} / \mathrm{g}$ & 4.21 & 0.16 & 4.05 & 0.09 & 4.09 & 0.12 & 3.80 & 0.33 & 3.50 & & 3.93 & 0.28 & 3.88 & 0.15 & 23 & Ref \\
\hline $\mathrm{Ta}, \mu \mathrm{g} / \mathrm{g}$ & 0.436 & 0.004 & 0.470 & & 0.485 & 0.007 & 0.464 & 0.038 & & & 0.464 & 0.021 & 0.464 & 0.021 & 22 & Ref \\
\hline $\mathrm{W}, \mu \mathrm{g} / \mathrm{g}$ & & & & & 0.90 & & 0.63 & 0.08 & 0.82 & & 0.78 & 0.14 & 0.69 & 0.12 & 8 & Ref \\
\hline $\mathrm{Re}, \mu \mathrm{g} / \mathrm{g}$ & & & & & & & 0.0018 & 0.0007 & & & 0.0018 & & 0.0018 & 0.002 & 3 & Inf \\
\hline \multicolumn{17}{|l|}{ Os, $\mu \mathrm{g} / \mathrm{g}$} \\
\hline $\mathrm{Ir}, \mu \mathrm{g} / \mathrm{g}$ & & & & & 0.2 & 0.3 & & & & & 0.2 & & 0.2 & & 2 & Inf \\
\hline $\mathrm{Pt}, \mu \mathrm{g} / \mathrm{g}$ & & & & & & & 6 & & & & 6 & & 6 & & 1 & Inf \\
\hline $\mathrm{Au}, \mu \mathrm{g} / \mathrm{g}$ & & & & & 0.09 & 0.01 & 0.11 & 0.09 & & & 0.10 & 0.01 & 0.10 & 0.11 & 4 & Inf \\
\hline $\mathrm{Hg}, \mu \mathrm{g} / \mathrm{g}$ & & & & & & & & & & & $<0.3$ & & $<0.3$ & & 1 & Inf \\
\hline $\mathrm{Tl}, \mu \mathrm{g} / \mathrm{g}$ & & & & & & & 0.13 & 0.06 & & & 0.13 & & 0.13 & 0.08 & 5 & Inf \\
\hline $\mathrm{Pb}, \mu \mathrm{g} / \mathrm{g}$ & & & 9.68 & 1.87 & 11.4 & & 12.0 & 3.10 & 10.0 & & 10.8 & 1.1 & 11.6 & 1.5 & 17 & Ref \\
\hline $\mathrm{Bi}, \mu \mathrm{g} / \mathrm{g}$ & & & & & 0.09 & & 0.10 & 0.05 & & & 0.10 & 0.00 & 0.10 & 0.05 & 6 & Inf \\
\hline $\mathrm{Th}, \mu \mathrm{g} / \mathrm{g}$ & & & 31.2 & 1.5 & 30.7 & 2.0 & 31.2 & 2.7 & 34.1 & & 31.8 & 1.5 & 31.3 & 1.0 & 26 & Ref \\
\hline $\mathrm{U}, \mu \mathrm{g} / \mathrm{g}$ & & & 1.72 & 0.08 & 1.67 & 0.17 & 1.72 & 0.26 & & & 1.70 & 0.03 & 1.71 & 0.10 & 24 & Ref \\
\hline
\end{tabular}

${ }^{\mathrm{a}}$ All techniques mean: average of 1-5 techn. groups means, Ov. (overall) mean: unweighted mean of all results, Ref: reference value, Inf: information value, SD: standard deviation, U: uncertainty at 95\% confidence level, n: number of analyses. BULK T.: XRF, SSMS, MIC-SSMS, MS, INAA, ICP-AES; MICRO T.: EPMA, SIMS, LIMS, SR-XRF, PIXE.

routine analytical technique for the determination of major element abundances. The other techniques were used for in situ trace element analyses. Homogeneous geological or NIST SRM glasses were mainly used for calibration.

[85] Tables 13a-13h list the concentration averages for each group with the corresponding SD values. The few outliers of auxiliary material Tables S1a-S1h are not considered. Nearly all mean values of the five groups agree within confidence intervals indicating that possible systematic differences between the techniques used are absent or small. Figure 5 shows a comparison of the mean element concentrations of each group with the reference values (Tables 13a-13h). It contains the data for the glasses KL-2G, ML3BG, ATHO-G, StHs6/80-G, T1-G having trace element concentrations in the $\mu \mathrm{g} / \mathrm{g}$ range. Each point in the figure represents a quite different number of analytical results; for example, in the case of ID: 2-10 data from 1-4 laboratories and LA-ICPMS: 20-90 different data obtained in 4-20 laboratories. Nearly all mean values agree within 5\% (relative deviation). With the exception of some elements, agreement of isotope dilution and LA-ICPMS data is even better. Some elements having low concentrations (e.g., Be, Sn, Cs, W) show larger deviations. This is also valid for elements in the trace element poor samples GOR128-G, GOR132-G and BM90/21-G where agreement is about $10 \%$ (relative deviation). This means that the results of the different analytical techniques are comparable.
Indications of systematic differences are insignificant. Especially promising are the mean concentration values of each group of analytical methods normalized to the respective reference values and averaged over all elements. These concentration ratios are $1.01 \pm 0.04(\mathrm{SD})$ for $\mathrm{ID}, 1.01 \pm 0.06$ (SD) for ICPMS, $1.02 \pm 0.09$ (SD) for other bulk analytical techniques, $0.99 \pm 0.04(\mathrm{SD})$ for LAICPMS, and $0.99 \pm 0.07$ (SD) for other microanalytical techniques. All mean values agree within confidence intervals with the reference values.

\subsection{Derivation of Preferred Values and Their Uncertainties}

[86] To obtain our preferred values of the MPI-DING glasses, we averaged the results of all contributing laboratories (auxiliary material Tables S1a-S1h). As recommended by the IAG [Kane et al., 2003] we used unweighted means because weighting procedures [Paule and Mandel, 1982] cannot be applied successfully to interlaboratory certification with 20 or more contributing laboratories. Similar to the procedure of Jochum et al. [2000] the results are classified in two categories: reference values and information values (Tables 13a-13h).

[87] Reference values were reported when they are derived from at least three laboratories using three or more independent, well-defined techniques that are in statistical agreement [Uriano and Gravatt, 1977]. IAG [Kane, 2004] based certified values on no fewer than 10 individual laboratory results using at least two independent methods of analysis 
Table 13h. Summary of Composition Data for ATHO-G ${ }^{\text {a }}$

\begin{tabular}{|c|c|c|c|c|c|c|c|c|c|c|c|c|c|c|c|c|}
\hline & \multicolumn{2}{|c|}{ ID } & \multicolumn{2}{|c|}{ ICPMS } & \multicolumn{2}{|c|}{ BULK T. } & \multicolumn{2}{|c|}{ LA-ICPMS } & \multicolumn{2}{|c|}{ MICRO T. } & \multicolumn{2}{|c|}{$\begin{array}{c}\text { All } \\
\text { Techniques }\end{array}$} & \multicolumn{4}{|c|}{ Preferred Value } \\
\hline & Mean & SD & Mean & $\mathrm{SD}$ & Mean & SD & Mean & SD & Mean & SD & Mean & SD & Ov. Mean & $\mathrm{U}$ & $\mathrm{n}$ & \\
\hline $\mathrm{H} 2 \mathrm{O}, \% \mathrm{~m} / \mathrm{m}$ & & & & & & & & & 0.014 & & 0.014 & & 0.014 & & 1 & $\operatorname{Inf}$ \\
\hline $\mathrm{Li}, \mu \mathrm{g} / \mathrm{g}$ & & & 25.1 & 1.5 & & & 28.9 & 2.6 & 30.0 & 2.3 & 28.0 & 2.6 & 28.6 & 1.8 & 12 & Ref \\
\hline $\mathrm{Be}, \mu \mathrm{g} / \mathrm{g}$ & & & & & & & 3.04 & 0.31 & 3.58 & 0.11 & 3.31 & 0.38 & 3.20 & 0.34 & 7 & Inf \\
\hline $\mathrm{B}, \mu \mathrm{g} / \mathrm{g}$ & & & & & & & 5.9 & 0.3 & 5.2 & 0.8 & 5.6 & 0.5 & 5.7 & 0.5 & 7 & Inf \\
\hline $\mathrm{CO} 2, \mu \mathrm{g} / \mathrm{g}$ & & & & & & & & & 3.7 & & 3.7 & & 3.7 & & 1 & Inf \\
\hline $\mathrm{O}, \% \mathrm{~m} / \mathrm{m}$ & & & & & & & & & 48.7 & & 48.7 & & 48.7 & & 1 & Inf \\
\hline $\mathrm{F}, \mu \mathrm{g} / \mathrm{g}$ & & & & & & & & & 0.7 & & 0.7 & & 0.7 & & 1 & Inf \\
\hline $\mathrm{Na} 2 \mathrm{O}, \% \mathrm{~m} / \mathrm{m}$ & & & & & 4.31 & 0.25 & 4.26 & & 3.53 & 0.48 & 4.03 & 0.44 & 3.75 & 0.31 & 14 & - Ref \\
\hline $\mathrm{MgO}, \% \mathrm{~m} / \mathrm{m}$ & & & & & 0.17 & & 0.11 & & 0.098 & 0.008 & 0.126 & 0.038 & 0.103 & 0.010 & 16 & Ref \\
\hline $\mathrm{Al} 2 \mathrm{O} 3, \% \mathrm{~m} / \mathrm{m}$ & & & & & 12.0 & & 11.7 & & 12.2 & 0.5 & 12.0 & 0.3 & 12.2 & 0.2 & 17 & Ref \\
\hline $\mathrm{SiO} 2, \% \mathrm{~m} / \mathrm{m}$ & & & & & 75.9 & & & & 75.6 & 1.3 & 75.7 & 0.2 & 75.6 & 0.7 & 16 & Ref \\
\hline $\mathrm{P} 2 \mathrm{O} 5, \% \mathrm{~m} / \mathrm{m}$ & & & & & 0.03 & & 0.020 & 0.001 & 0.027 & & 0.025 & 0.005 & 0.025 & 0.004 & 7 & Ref \\
\hline $\mathrm{S}, \mu \mathrm{g} / \mathrm{g}$ & & & & & & & & & 0.6 & & 0.6 & & 0.6 & & 1 & Inf \\
\hline $\mathrm{Cl}, \mu \mathrm{g} / \mathrm{g}$ & & & & & & & & & 2430 & & 2430 & & 2430 & & 7 & Inf \\
\hline $\mathrm{K} 2 \mathrm{O}, \% \mathrm{~m} / \mathrm{m}$ & 2.70 & & & & 2.65 & 0.12 & 2.86 & & 2.62 & 0.23 & 2.71 & 0.11 & 2.64 & 0.09 & 21 & Ref \\
\hline $\mathrm{CaO}, \% \mathrm{~m} / \mathrm{m}$ & & & & & 1.67 & & 1.76 & 0.09 & 1.69 & 0.06 & 1.71 & 0.04 & 1.70 & 0.03 & 17 & Ref \\
\hline $\mathrm{Sc}, \mu \mathrm{g} / \mathrm{g}$ & & & 4.9 & & 5.1 & 0.1 & 7.6 & 1.5 & 6.0 & & 5.9 & 1.3 & 7.0 & 0.9 & 15 & Ref \\
\hline $\mathrm{TiO} 2, \% \mathrm{~m} / \mathrm{m}$ & & & & & 0.240 & & 0.282 & 0.043 & 0.241 & 0.031 & 0.254 & 0.024 & 0.255 & 0.016 & 27 & Ref \\
\hline $\mathrm{V}, \mu \mathrm{g} / \mathrm{g}$ & & & & & & & 3.80 & 0.65 & 4.36 & 0.27 & 4.08 & 0.39 & 3.91 & 0.34 & 16 & Ref \\
\hline $\mathrm{Cr}, \mu \mathrm{g} / \mathrm{g}$ & & & & & 11 & & 6.0 & 2.1 & 5.3 & 0.6 & 7.4 & 3.1 & 6.1 & 1.4 & 13 & Ref \\
\hline $\mathrm{MnO}, \% \mathrm{~m} / \mathrm{m}$ & & & & & 0.102 & 0.003 & 0.106 & 0.009 & 0.108 & 0.013 & 0.105 & 0.003 & 0.106 & 0.005 & 24 & - Ref \\
\hline $\mathrm{FeO} \mathrm{T}, \% \mathrm{~m} / \mathrm{m}$ & & & & & 3.13 & 0.15 & 3.00 & & 3.32 & 0.20 & 3.15 & 0.16 & 3.27 & 0.10 & 20 & Ref \\
\hline $\mathrm{Co}, \mu \mathrm{g} / \mathrm{g}$ & & & 2.30 & & 2.61 & 0.06 & 2.08 & 1.10 & 1.91 & 0.01 & 2.22 & 0.30 & 2.13 & 0.47 & 18 & Ref \\
\hline $\mathrm{Ni}, \mu \mathrm{g} / \mathrm{g}$ & & & 23 & & 20 & & 12 & 10 & 12 & 9 & 17 & 6 & 13 & 5 & 17 & Ref \\
\hline $\mathrm{Cu}, \mu \mathrm{g} / \mathrm{g}$ & & & 18.0 & & & & 17.7 & 2.9 & 21.4 & 2.0 & 19.0 & 2.1 & 18.6 & 2.2 & 13 & Ref \\
\hline $\mathrm{Zn}, \mu \mathrm{g} / \mathrm{g}$ & & & 118 & & 121 & 13 & 143 & 16 & 153 & 13 & 134 & 17 & 141 & 15 & 12 & Ref \\
\hline $\mathrm{Ga}, \mu \mathrm{g} / \mathrm{g}$ & & & 22.0 & & 21.5 & 0.7 & 26.9 & 4.7 & 25.3 & 1.3 & 23.9 & 2.6 & 25.3 & 2.4 & 13 & Ref \\
\hline Ge, $\mu \mathrm{g} / \mathrm{g}$ & & & & & & & 1.8 & 0.8 & 1.6 & & 1.7 & 0.2 & 1.8 & 0.9 & 5 & Inf \\
\hline As, $\mu \mathrm{g} / \mathrm{g}$ & & & & & 0.8 & 0.0 & 1.6 & 0.5 & 1.8 & & 1.4 & 0.5 & 1.4 & 0.5 & 7 & Ref \\
\hline $\mathrm{Se}$, & & & & & & & 0.10 & & & & 0.10 & & 0.10 & & 1 & Inf \\
\hline $\mathrm{Br}$, & & & & & 1.2 & 0.1 & & & 1.1 & & 1.2 & 0.1 & & 0.3 & 3 & Inf \\
\hline $\mathrm{Rb}$, & 63.8 & & 61.0 & 3.5 & 65.0 & 0.9 & 66.2 & 8.5 & 64.5 & 7.7 & 6 & 1.9 & 6 & 3.0 & 26 & Ref \\
\hline $\mathrm{Sr}$, & 96.0 & 0.1 & 93.6 & 6.5 & 108.0 & & 91.1 & 7.3 & 99.7 & 6.8 & 97.7 & 6.6 & 94.1 & 2.7 & 34 & - Ref \\
\hline $\mathrm{Y}, \mu \mathrm{g} / \mathrm{g}$ & & & 90.8 & 4.9 & & & 93.7 & 10.0 & 97.7 & 10.9 & 94.1 & 3.5 & 94.5 & 3.5 & 31 & Ref \\
\hline $\mathrm{Zr}, \mu \mathrm{g} / \mathrm{g}$ & 519 & 14 & 509 & 9 & 600 & & 497 & 58 & 537 & 59 & 532 & 41 & 512 & 20 & 33 & Ref \\
\hline $\mathrm{Nb}, \mu \mathrm{g} / \mathrm{g}$ & & & 59.6 & 7.1 & & & 62.5 & 7.6 & 63.5 & 3.0 & 61.9 & 2.1 & 62.4 & 2.6 & 27 & Ref \\
\hline Mo, $\mu \mathrm{g} / \mathrm{g}$ & & & 5.8 & & 7.0 & & 4.1 & 0.7 & 5.5 & 2.1 & 5.6 & 1.2 & 4.8 & 1.0 & 10 & Ref \\
\hline & & & & & & & & & & & & & & & & \\
\hline $\mathrm{Pd}, \mathrm{r}$ & & & & & $<\mathbf{2 0}$ & & & & & & $<\mathbf{2 0}$ & & $<\mathbf{2 0}$ & & 1 & \\
\hline $\mathrm{Ag}$, & & & & & & & 0.3 & 0.2 & & & 0.3 & & $\mathbf{0}$ & & 2 & Inf \\
\hline $\mathrm{g}$ & & & & & & & 0.5 & 0.6 & & & 0.5 & & 0 & & 3 & Inf \\
\hline In, & & & & & & & 0.17 & 0.07 & & & 0.17 & & 0.17 & & 3 & Inf \\
\hline $\mathrm{lg} / \mathrm{g}$ & & & 4.70 & & & & 5 & 1.01 & 5.00 & & 5 & 0 & 5 & 0.73 & 11 & Ref \\
\hline $\mathrm{Sb}$ & & & 0.27 & & 0.39 & 0.16 & 0.27 & 0.10 & 0.46 & & 0.35 & 0.09 & 0.32 & 0.10 & 8 & Ref \\
\hline $\mathrm{Cs}, \mu \mathrm{g} / \mathrm{g}$ & & & 1.36 & & 1.40 & & 0.97 & 0.12 & 1.15 & 0.35 & 1.22 & 0.20 & 1.08 & 0.11 & 18 & Ref \\
\hline $\mathrm{Ba}, \mu \mathrm{g} / \mathrm{g}$ & 559 & 12 & 544 & 13 & 540 & 28 & 529 & 47 & 585 & 44 & 551 & 22 & 547 & 16 & 34 & - Ref \\
\hline $\mathrm{La}, \mu \mathrm{g} / \mathrm{g}$ & 56.0 & & 55.2 & 2.5 & 56.0 & 2.8 & 55.9 & 4.3 & 54.8 & 6.8 & 55.6 & 0.6 & 55.6 & 1.5 & 34 & - Ref \\
\hline $\mathrm{Ce}, \mu \mathrm{g} / \mathrm{g}$ & 123 & & 118 & 1 & 125 & 10 & 123 & 9 & 118 & 11 & 121 & 3 & 121 & 4 & 34 & - Ref \\
\hline $\operatorname{Pr}, \mu \mathrm{g} / \mathrm{g}$ & & & 15.3 & 0.5 & 13.8 & 1.1 & 14.7 & 1.0 & 13.8 & 1.0 & 14.4 & 0.7 & 14.6 & 0.4 & 26 & Ref \\
\hline $\mathrm{Nd}, \mathrm{r}$ & 63.7 & 1.4 & 60.0 & 1.7 & 62.9 & 3. & 60.8 & 4.6 & 59.5 & 6.3 & 61.4 & 1.8 & 60.9 & 2.0 & 23 & Ref \\
\hline $\mathrm{Sm}$ & 14.6 & 0.2 & 14.2 & 0.7 & 15.4 & 0 . & 14 & 1.3 & 12.8 & 0.4 & 14.2 & 1.0 & 14.2 & 0.4 & 32 & Ref \\
\hline $\mathrm{Eu}$, & 2.89 & & 2.86 & 0.10 & 2.84 & 0.20 & 2. & 0.27 & 2.64 & 0.96 & 2.79 & 0.10 & 2.76 & 0.10 & 30 & Ref \\
\hline $\mathrm{Gd}, \mathrm{r}$ & 15.3 & & 15.6 & 1.2 & 16.5 & & & 1.4 & & 3.4 & & 0.7 & 15.3 & 0.7 & 28 & Ref \\
\hline $\mathrm{Tb}, \mu \mathrm{g} / \mathrm{g}$ & & & 2.59 & 0.10 & 2.67 & 0.08 & 2.49 & 0.20 & 2.38 & 0.29 & 2.53 & 0.12 & 2.51 & 0.08 & 23 & Ref \\
\hline Dy, $\mu \mathrm{g} / \mathrm{g}$ & 16.6 & 0.2 & 16.3 & 0.6 & 15.5 & 0.7 & 16.8 & 1.4 & 14.3 & 0.8 & 15.9 & 1.0 & 16.2 & 0.7 & 20 & Ref \\
\hline Ho, $\mu \mathrm{g} / \mathrm{g}$ & & & 3.44 & 0.10 & 3.42 & 0.17 & 3.48 & 0.30 & 3.15 & 0.07 & 3.37 & 0.15 & 3.43 & 0.11 & 25 & Ref \\
\hline $\mathrm{Er}, \mu \mathrm{g} / \mathrm{g}$ & 10.6 & 0.1 & 10.3 & 0.6 & 10.0 & & 10.5 & 1.0 & 9.6 & 1.0 & 10.2 & 0.4 & 10.3 & 0.5 & 27 & Ref \\
\hline $\mathrm{Tm}, \mu \mathrm{g} / \mathrm{g}$ & & & 1.52 & 0.06 & & & 1.55 & 0.15 & 1.37 & 0.10 & 1.48 & 0.10 & 1.52 & 0.07 & 20 & Ref \\
\hline $\mathrm{Yb}, \mu \mathrm{g} / \mathrm{g}$ & 10.2 & 0.4 & 10.0 & 0.2 & 10.3 & 0.5 & 10.8 & 1.0 & 9.9 & 0.5 & 10.2 & 0.4 & 10.5 & 0.4 & 31 & Ref \\
\hline $\mathrm{Lu}, \mu \mathrm{g} / \mathrm{g}$ & 1.54 & & 1.52 & 0.05 & 1.57 & 0.09 & 1.56 & 0.14 & 1.40 & 0.09 & 1.52 & 0.07 & 1.54 & 0.05 & 28 & Ref \\
\hline
\end{tabular}


Table 13h. (continued)

\begin{tabular}{|c|c|c|c|c|c|c|c|c|c|c|c|c|c|c|c|c|}
\hline & \multicolumn{2}{|c|}{ ID } & \multicolumn{2}{|c|}{ ICPMS } & \multicolumn{2}{|c|}{ BULK T. } & \multicolumn{2}{|c|}{ LA-ICPMS } & \multicolumn{2}{|c|}{ MICRO T. } & \multicolumn{2}{|c|}{$\begin{array}{c}\text { All } \\
\text { Techniques }\end{array}$} & \multicolumn{4}{|c|}{ Preferred Value } \\
\hline & Mean & $\mathrm{SD}$ & Mean & $\mathrm{SD}$ & Mean & SD & Mean & SD & Mean & SD & Mean & SD & Ov. Mean & $\mathrm{U}$ & $\mathrm{n}$ & \\
\hline Hf, $\mu \mathrm{g} / \mathrm{g}$ & 13.5 & 0.5 & 14.1 & 0.1 & 14.1 & 0.1 & 13.7 & 1.4 & 13.0 & 0.8 & 13.7 & 0.5 & 13.7 & 0.5 & 27 & Ref \\
\hline $\mathrm{Ta}, \mu \mathrm{g} / \mathrm{g}$ & 3.57 & 0.04 & 3.66 & 0.23 & 3.85 & 0.23 & 3.97 & 0.52 & 4.10 & & 3.83 & 0.22 & 3.90 & 0.20 & 23 & Ref \\
\hline $\mathrm{W}, \mu \mathrm{g} / \mathrm{g}$ & & & & & 8.2 & 0.5 & 9.6 & 2.0 & 9.6 & 0.6 & 9.1 & 0.8 & 9.3 & 1.2 & 10 & Ref \\
\hline $\mathrm{Re}, \mu \mathrm{g} / \mathrm{g}$ & & & & & & & 0.0005 & 0.0001 & & & 0.0005 & & 0.0005 & & 3 & Inf \\
\hline Os, $\mu \mathrm{g} / \mathrm{g}$ & & & & & $<2$ & & & & & & $<2$ & & $<2$ & & 1 & Inf \\
\hline $\mathrm{Ir}, \mu \mathrm{g} / \mathrm{g}$ & & & & & 0.09 & 0.01 & & & & & 0.09 & & 0.09 & & 2 & Inf \\
\hline $\mathrm{Pt}, \mu \mathrm{g} / \mathrm{g}$ & & & & & 12 & 2 & 0.2 & & & & 6 & 9 & 8 & & 3 & $\operatorname{Inf}$ \\
\hline $\mathrm{Au}, \mu \mathrm{g} / \mathrm{g}$ & & & & & 0.02 & 0.00 & 0.04 & 0.02 & & & 0.03 & 0.01 & 0.03 & 0.03 & 4 & Inf \\
\hline $\mathrm{Hg}, \mu \mathrm{g} / \mathrm{g}$ & & & & & $<1$ & & & & & & $<1$ & & $<1$ & & 1 & Inf \\
\hline $\mathrm{Tl}, \mu \mathrm{g} / \mathrm{g}$ & & & & & & & 0.07 & 0.01 & & & 0.07 & & 0.07 & & 3 & $\operatorname{Inf}$ \\
\hline $\mathrm{Pb}, \mu \mathrm{g} / \mathrm{g}$ & 5.57 & & 4.46 & 0.91 & & & 5.64 & 1.30 & 7.10 & 1.27 & 5.69 & 1.08 & 5.67 & 0.62 & 20 & Ref \\
\hline $\mathrm{Bi}, \mu \mathrm{g} / \mathrm{g}$ & & & & & 0.09 & & 0.03 & 0.01 & & & 0.06 & & 0.05 & & 3 & Inf \\
\hline $\mathrm{Th}, \mu \mathrm{g} / \mathrm{g}$ & & & 6.76 & 1.16 & 6.70 & 0.93 & 7.62 & 0.72 & 7.49 & 0.41 & 7.14 & 0.48 & 7.40 & 0.27 & 29 & Ref \\
\hline $\mathrm{U}, \mu \mathrm{g} / \mathrm{g}$ & 1.85 & & 2.13 & 0.07 & 2.22 & 0.22 & 2.46 & 0.28 & & & 2.16 & 0.25 & 2.37 & 0.12 & 26 & Ref \\
\hline
\end{tabular}

${ }^{a}$ All techniques mean: average of 1-5 techn. groups means, Ov. (overall) mean: unweighted mean of all results, Ref: reference value, Inf: information value, SD: standard deviation, U: uncertainty at 95\% confidence level, n: number of analyses. BULK T.: XRF, SSMS, MIC-SSMS, MS, INAA, ICP-AES; MICRO T.: EPMA, SIMS, LIMS, SR-XRF, PIXE.

that are in agreement. We used both recommendations for establishment of reference values. The second criterion is of particular importance for some major element data for which too few analytical techniques have been applied. Those elements that were determined by one or two techniques and fewer than ten laboratories are assigned information values rather than reference values. Most data of Tables 13a-13h belong to the category of reference values. Exceptions are some trace elements that are normally not measured in routine geochemical analysis (e.g., $\mathrm{Be}, \mathrm{Se}, \mathrm{Br}, \mathrm{Bi}$ ).
[88] According to the IAG protocol [Kane et al., 2003] uncertainty " $u$ " of the MPI-DING glass data is mainly based on three components of variance which have been combined in quadrature:

$$
\mathrm{u}^{2}=\operatorname{VAR}\left(\mathrm{Y}_{\text {mean }} / \sqrt{ } \mathrm{n}\right)+\mathrm{VAR}_{\text {inhomo }}+\mathrm{VAR}_{\text {bias }}
$$

The first component, the standard deviation of the mean $\mathrm{Y}_{\text {mean }}$ of $n$ contributing laboratory mean data, will be used as the random component of variance. $\mathrm{VAR}_{\text {inhomo }}$ accounts for inhomogeneities in the glasses and $\mathrm{VAR}_{\text {bias }}$ for between-laboratory biases.

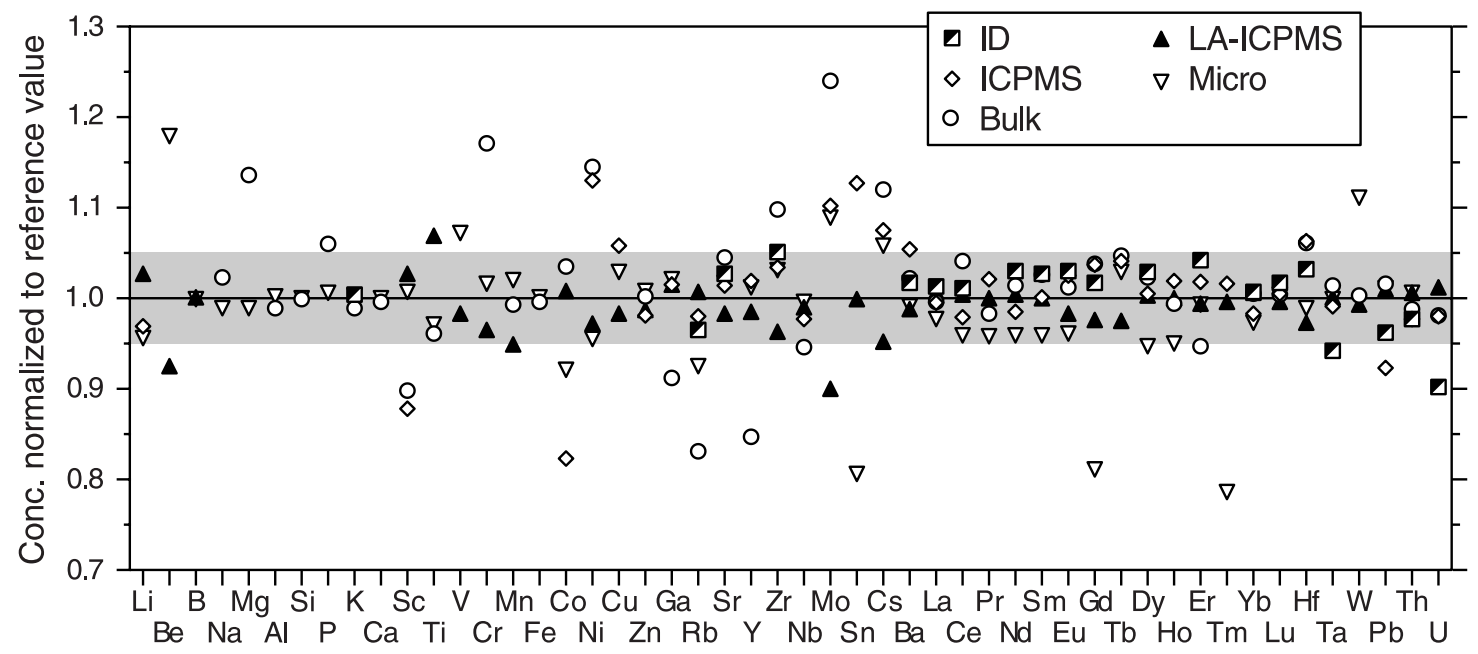

Figure 5. Mean concentrations in KL-2G, ML3B-G, StHs6/80-G, T1-G, and ATHO-G obtained by five different groups of analytical methods (Tables 13a, 13b,13c, 13g, and 13h) normalized to the respective reference values (overall means). Nearly all values agree within $5 \%$, indicating that all methods are comparable. Elements having low concentrations show generally larger deviations. 


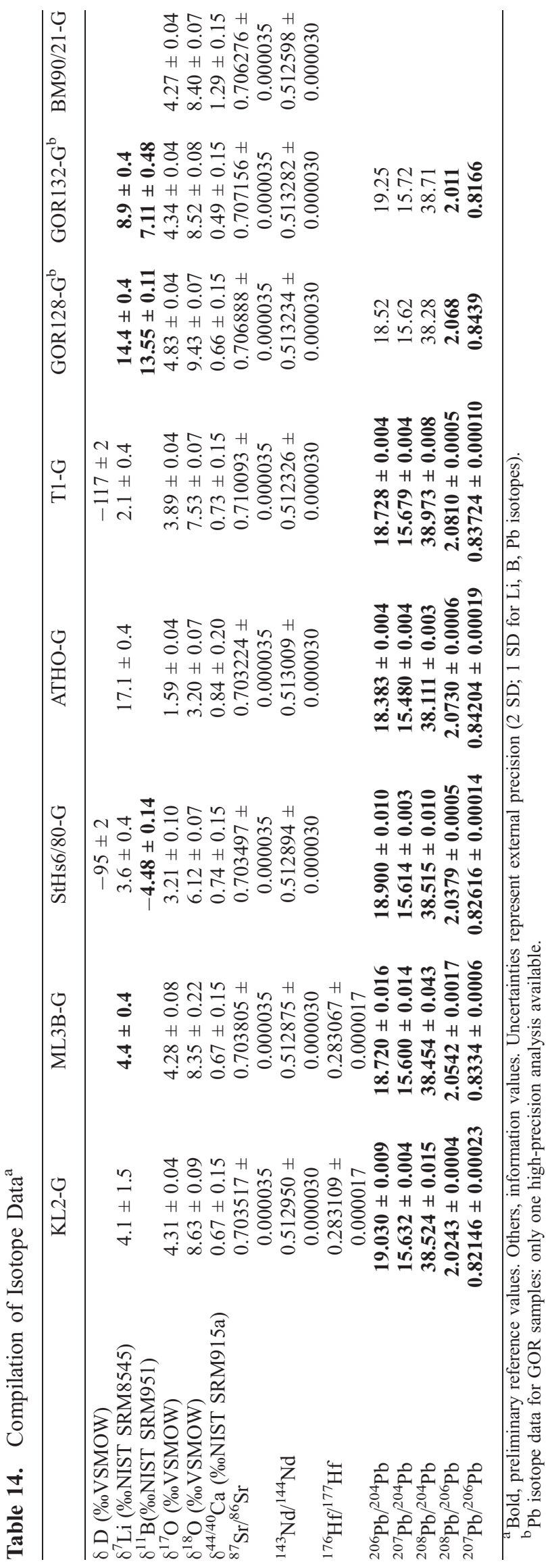


The last two components affect only few element data. There are only some elements (e.g., $\mathrm{Cu}, \mathrm{Sn}$, $\mathrm{Bi}$ ) that are heterogeneously distributed in the glasses (see section 3.1). A RSD of 3\% is used to calculate $\mathrm{VAR}_{\text {inhomo }}$ for $\mathrm{Cu}, \mathrm{Sn}, \mathrm{Bi}$. Because the collaborating laboratories are qualified, biases are expected to be small and are likely to be normally distributed so that they will be included in the standard deviation of the mean.

[89] The uncertainty $U$ of the reference value at $95 \%$ confidence level is

$$
\mathrm{U}=\mathrm{ku}
$$

where $\mathrm{k}$ is the Student's t factor. It is about 2 for $\mathrm{n}>30$ and larger at small $\mathrm{n}$.

[90] As shown in Tables 13a-13h most reference values agree within confidence intervals with the mean values obtained from the averages of the five groups of analytical techniques. Most data also agree within error limits with the preliminary reference values by Jochum et al. [2000]; however, the new data are more reliable because of more data.

[91] Table 14 shows a compilation of the isotope data of the MPI-DING glasses. Most measurements were only done with one analytical method. These results are therefore only for information. However, the data are reliable because they were obtained by well-established high-precision bulk (mainly TIMS) and microanalytical techniques. Boron and $\mathrm{Pb}$ isotope measurements were done in different laboratories using TIMS and MC-ICPMS. Mean triple spike $\mathrm{Pb}$ values of NIST SRM 981 obtained at Mainz $\left({ }^{208} \mathrm{~Pb} /{ }^{204} \mathrm{~Pb}=36.7245,{ }^{207} \mathrm{~Pb} /{ }^{204} \mathrm{~Pb}=\right.$ $15.4971,{ }^{206} \mathrm{~Pb} /{ }^{204} \mathrm{~Pb}=16.9407,{ }^{208} \mathrm{~Pb} /{ }^{206} \mathrm{~Pb}=$ $\left.2.16782,{ }^{207} \mathrm{~Pb} /{ }^{206} \mathrm{~Pb}=0.91479\right)$ [see Baker et al., 2004] were used for normalization. The MPI-DING data were confirmed by microanalytical techniques (LA-MC-ICPMS, LA-ICPMS). Boron and $\mathrm{Pb}$ isotope data may be assigned to the group of reference values. This may be also the case for some Li isotopes where MC-ICPMS and SIMS values agree within their respective confidence intervals.

\section{Conclusions}

[92] The MPI-DING glasses are a suitable set of reference materials for in situ microanalytical work. The minimum test portion masses at which the samples appear homogeneous are about 5$20 \mathrm{ng}$. For each sample reference and information values for up to 74 major and trace elements have been determined following the recommendations of the IAG. In the geochemical characterization of the MPI-DING glasses more than 60 laboratories were involved using 16 independent methods. For most elements the reference values are established to a high degree of reliability. This is especially true for the major elements and $\mathrm{Li}, \mathrm{Sc}, \mathrm{V}, \mathrm{Cr}, \mathrm{Co}$, $\mathrm{Ni}, \mathrm{Cu}, \mathrm{Zn}, \mathrm{Ga}, \mathrm{Rb}, \mathrm{Sr}, \mathrm{Y}, \mathrm{Zr}, \mathrm{Nb}, \mathrm{Mo}, \mathrm{Cs}, \mathrm{Ba}$, REE, Hf, Ta Pb, Th and U where generally 10-34 analytical results were available. However, others, such as F, S, Cl, Ge, As, Se, Br, Sb, W, Tl, Bi, were not routinely analyzed by most laboratories. Further analyses are necessary for these trace elements.

[93] The isotopic composition of $\mathrm{H}, \mathrm{Li}, \mathrm{B}, \mathrm{O}, \mathrm{Ca}$, $\mathrm{Sr}, \mathrm{Nd}$, $\mathrm{Hf}$ and $\mathrm{Pb}$ was determined by one to four different techniques. The reliability of the isotope data is high because in most cases high-precision bulk techniques were used. Small isotopic heterogeneities of $\mathrm{Li}$, and $\mathrm{Pb}$ found in some MPI-DING glasses may be a feature to be taken seriously. However, in the case of $\mathrm{Pb}$ they are generally lower than the reproducibility obtained from in situ microanalytical techniques, such as SIMS and LA-ICPMS. However, further microanalytical investigations are needed for all isotope systems.

\section{Availability}

[94] Small amounts of the MPI-DING reference glasses can be obtained on request (e-mail addresses: kpj@mpch-mainz.mpg.de or stoll@ mpch-mainz.mpg.de).

\section{Acknowledgments}

[95] Many people were involved in the geochemical characterization of the MPI-DING glasses. We thank all of them who have contributed to the extensive database. The new geochemical database for reference materials and isotopic standards (http://georem.mpch-mainz.gwdg.de) was helpful. We thank the reviewers Marion Carpentier and Jean Carignan and the Associate Editor Catherine Chauvel for their valuable comments.

\section{References}

Amini, M. (2003), Geochemistry of fresh submarine glasses from the Hawaii Scientific Drilling Project-2, diploma thesis, Univ. Mainz, Mainz, Germany.

Armstrong, J. T. (1991), Quantitative elemental analysis of individual microparticles with electron beam instruments, in Electron Probe Quantitation, edited by K. F. J. Heinrich and D. E. Newbury, pp. 261-315, Springer, New York.

Badanina, E. V., I. V. Veksler, R. Thomas, L. F. Syritso, and R. B. Trumbull (2004), Magmatic evolution of Li-F, rare- 
metal granites: A case study of melt inclusions in the Khangilay complex, Eastern Transbaikalia (Russia), Chem. Geol., 210, 113-133.

Baker, J., D. Peate, T. Waight, and C. Meyzen (2004), Pb isotopic analysis of standards and samples using a ${ }^{207} \mathrm{~Pb}-{ }^{204} \mathrm{~Pb}$ double spike and thallium to correct for mass bias with a double-focusing MC-ICP-MS, Chem. Geol., 211, 275-303.

Becker, J. S., and H.-J. Dietze (1999), Determination of trace elements in geological samples by laser ablation inductively coupled plasma mass spectrometry, Fresenius J. Anal. Chem., 365, 429-434.

Becker, J. S., C. Pickhardt, and H.-J. Dietze (2000), Laser ablation inductively coupled plasma mass spectrometry for determination of trace elements in geological glasses, Mikrochim. Acta, 135, 71-80.

Becker, J. Su., C. Pickhardt, N. Hoffmann, H. Höcker, and J. Sa. Becker (2002), Multielement analysis of alkalineresistant glass and basalt glass fibers using laser ablation ICP-MS: A useful tool in technical textile quality control, At. Spectrosc., 23, 1-6.

Bizzarro, M., J. A. Baker, and D. Ulfbeck (2003), A new digestion and chemical separation technique for rapid and highly reproducible determination of $\mathrm{Lu} / \mathrm{Hf}$ and $\mathrm{Hf}$ isotope ratios in geological materials by MC-ICP-MS, Geostand. Newsl., 27, 133-145.

Blichert-Toft, J. (2001), On the Lu-Hf chemistry of silicate rocks, Geostand. Newsl., 25, 41-56.

Blichert-Toft, J., F. A. Frey, and F. Albarède (1999), Hf isotope evidence for pelagic sediments in the source of Hawaiian basalts, Science, 285, 879-882.

Canil, D., D. J. Schulze, D. Hall, B. C. Hearn, Jr., and S. M. Milliken (2003), Lithospheric roots beneath western Laurentia: The geochemical signal in mantle garnets, Can. J. Earth Sci., 40, 1027-1051.

Chaussidon, M., and B. Marty (1995), Primitive boron isotope composition of the mantle, Science, 269, 383-386.

DePaolo, D. J. (2004), Calcium isotopic variations produced by biological, kinetic, radiogenic and nucleosynthetic processes, Rev. Mineral. Geochem., 55, 255-288.

Dingwell, D., N. Bagdassarov, N. Bussod, and S. L. Webb (1993), Magma rheology, in Short Course on Experiments at High Pressure and Applications to the Earth's Mantle, edited by R. W. Luth, vol. 21, pp. 131-196, Mineral. Assoc. of Can., Edmonton, Canada.

Eggins, S. M., and J. M. G. Shelley (2002), Compositional heterogeneity in NIST SRM 610-617 glasses, Geostandards Newsletter, 26, 269-286.

Eisenhauer, A., T. F. Nägler, P. Stille, J. Kramers, N. Gussone, B. Bock, J. Fietzke, D. Hippler, and A.-D. Schmitt (2004), Proposal for international agreement on Ca notation resulting from discussions at workshops on stable isotope measurements held in Davos (Goldschmidt 2002) and Nice (EGSAGU-EUG 2003), Geostand. Geoanal. Res., 28, 149-151.

Eurachem (2000), Quantifying Uncertainty in Analytical Measurement (Guide on Uncertainty in Measurement), 2nd ed., 111 pp. (Available at http://www.eurachem.ul.pt)

Galer, S. J. G. (1999), Optimal double and triple spiking for high precision lead isotopic measurement, Chem. Geol., 157, 255-274.

Garbe-Schönberg, C. D. (1993), Simultaneous determination of thirty-seven trace elements in twenty-eight international rock standards by ICP-MS, Geostand. Newsl., 17, 81-97.

Govindaraju, K. (1994), 1994 compilation of working values and sample description for 383 geostandards, Geostand. Newsl., 18, 1-158.
Grevemeyer, I., B. Schramm, C. W. Devey, D. S. Wilson, B. Jochum, J. Hauschild, K. Aric, H. W. Villinger, and W. Weigel (2002), A multibeam-sonar, magnetic and geochemical flowline survey at $14^{\circ} 14^{\prime} \mathrm{S}$ on the southern East Pacific Rise: Insights into the fourth dimension of ridge crest segmentation, Earth Planet. Sci. Lett., 199, 359-372.

Guillong, M., I. Horn, and D. Günther (2002), Capabilities of a homogenized $266 \mathrm{~nm} \mathrm{Nd:YAG} \mathrm{laser} \mathrm{ablation} \mathrm{system} \mathrm{for} \mathrm{LA-}$ ICP-MS, J. Anal. At. Spectrom., 17, 8-14.

Günther, D., R. Frischknecht, and C. A. Heinrich (1997), Capabilities of a $193 \mathrm{~nm} \mathrm{ArF} \mathrm{excimer} \mathrm{laser} \mathrm{for} \mathrm{LA-ICP-MS}$ micro analysis of geological materials, J. Anal. At. Spectrom., 12, 939-944.

Harmon, R. S., and J. Hoefs (1995), Oxygen isotope heterogeneity of the mantle deduced from global systematics of basalts from different geotectonic settings, Contrib. Mineral. Petrol., 120, 95-114.

Hauri, E. H., J. Wang, J. E. Dixon, P. L. King, C. Mandeville, and S. Newman (2002), SIMS analysis of volatiles in silicate glasses, 1. Calibration, matrix effects and comparisons with FTIR, Chem. Geol., 183, 99-114.

Hellebrand, E., and J. E. Snow (2003), Deep melting and sodic metasomatism underneath the highly oblique-spreading Lena Trough (Arctic Ocean), Earth Planet. Sci. Lett., 216, $283-$ 299.

Hellebrand, E., J. E. Snow, H. J. B. Dick, and A. W. Hofmann (2001), Coupled major and trace elements as indicators of the extent of melting in mid-ocean-ridge peridotites, Nature, $410,677-681$

Hellebrand, E., J. E. Snow, P. Hoppe, and A. W. Hofmann (2002), Garnet-field melting and late-stage refertilization in 'residual' abyssal peridotites from the Central Indian Ridge, J. Petrol., 43, 2305-2338.

Heumann, K. G. (1988), Isotope dilution mass spectrometry, in Inorganic Mass Spectrometry, edited by F. Adams, R. Gijbels, and R. van Grieken, pp. 301-311, John Wiley, Hoboken, N. J.

Heuser, A., A. Eisenhauer, N. Gussone, B. Bock, B. T. Hansen, and T. F. Nägler (2002), Measurement of calcium isotopes $\left(\delta^{44} \mathrm{Ca}\right)$ using a multicollector TIMS technique, Int. J. Mass Spectrom., 220, 385-397.

Hippler, D., A.-D. Schmidt, N. Gussone, A. Heuser, P. Stille, A. Eisenhauer, and T. F. Nägler (2003), Calcium isotopic composition of various reference materials and seawater, Geostand. Newsl., 27, 13-19.

Hoppe, P., J. N. Goswami, U. Krähenbühl, and K. Marti (2001), Boron in chondrules, Meteorit. Planet. Sci., 36, $1331-1343$.

Horn, I., R. L. Rudnick, and W. F. McDonough (2000), Precise elemental and isotope ratio determination by combined solution nebulization and laser ablation-ICP-MS: Application to U/Pb geochronology, Chem. Geol., 161, 281-301.

Horz, K. H., T. J. Worthington, K. Winn, and P. Stoffers (2004), Late Quaternary tephra in the New Ireland Basin, Papua New Guinea, J. Volcanol. Geotherm. Res., 132, 73-95.

International Organization for Standardization (ISO) (1989), Certification of Reference Materials: General and Statistical Principles, ISO Guide 35, 32 pp., Geneva.

International Organization for Standardization (ISO) (1992), Terms and Definitions Used in Connection With Reference Materials, 2nd ed., ISO Guide 30, 8 pp., Geneva.

Jarosewich, E., J. A. Nelen, and J. A. Norberg (1980), Reference standards for electron microprobe analysis, Geostand. Newsl., 4, 43-47.

Jeffcoate, A. B., T. Elliott, A. Thomas, and C. Bouman (2004), Precise, small sample size determinations of lithium isotopic 
compositions of geological reference materials and modern seawater by MC-ICP-MS, Geostand. Geoanal. Res., 28, $161-172$

Jochum, K. P., et al. (2000), The preparation and preliminary characterisation of eight geological MPI-DING reference glasses for in-situ microanalysis, Geostand. Newsl., 24, $87-133$.

Jochum, K. P., B. Stoll, K. Herwig, M. Amini, W. Abouchami, and A. W. Hofmann (2005a), Lead isotope ratio measurements in geological glasses by laser ablation-sector fieldICP mass spectrometry (LA-SF-ICPMS), Int. J. Mass Spectrom., 242, 281-289.

Jochum, K. P., J. Pfänder, J. D. Woodhead, M. Willbold, B. Stoll, K. Herwig, M. Amini, W. Abouchami, and A. W. Hofmann (2005b), MPI-DING glasses: New geological reference materials for in situ $\mathrm{Pb}$ isotope analysis, Geochem. Geophys. Geosyst., 6, Q10008, doi:10.1029/2005GC000995.

Jochum, K. P., M. Willbold, I. Raczek, B. Stoll, and K. Herwig (2005c), Chemical characterisation of the USGS reference glasses GSA-1G, GSC-1G, GSD-1G, GSE-1G, BCR-2G, BHVO-2G and BIR-1G using EPMA, ID-TIMS, ID-ICPMS and LA-ICPMS, Geostand. Geoanal. Res., 29, 285-302.

Johnston, A. D., and B. E. Schwab (2004), Constraints on clinopyroxene/melt partitioning of REE, $\mathrm{Rb}, \mathrm{Sr}, \mathrm{Ti}, \mathrm{Cr}, \mathrm{Zr}$, and $\mathrm{Nb}$ during mantle melting: First insights from direct peridotite melting experiments at $1.0 \mathrm{Gpa}$, Geochim. Cosmochim. Acta, 68, 4949-4962.

Kane, J. S. (2002), Fitness-for-purpose of reference material reference values in relation to traceability of measurement, as illustrated by USGS BCR-1, NIST SRM 610 and IAEA NBS28, Geostand. Newsl., 26, 7-29.

Kane, J. S. (2004), Report of the International Association of Geoanalysts on the certification of Penrhyn Slate, OU-6, Geostand. Geoanal. Res., 28, 53-80.

Kane, J. S., and P. J. Potts (1997), ISO Guides for reference material certification and use: Application to geochemical reference materials, Geostand. Newsl., 21, 51-58.

Kane, J. S., and P. J. Potts (1999), An interpretation of ISO Guidelines for the certification of geological reference materials, Geostand. Newsl., 23, 209-221.

Kane, J. S., P. J. Potts, M. Wiedenbeck, J. Carignan, and S. Wilson (2003), International Association of Geoanalysts' protocol for the certification of geological and environmental reference materials, Geostand. Newsl., 27, 227-244.

Kasemann, S., A. Meixner, A. Rocholl, T. Vennemann, M. Rosner, A. K. Schmitt, and M. Wiedenbeck (2001), Boron and oxygen isotope composition of certified reference materials NIST SRM 610/612 and reference materials JB-2 and JR-2, Geostand. Newsl., 25, 405-416.

Kasemann, S. A., A. B. Jeffcoate, and T. Elliott (2005), Lithium isotope composition of basalt glass reference material, Anal. Chem., 77, 5251-5257.

Kelley, K. A., T. Plank, J. Ludden, and H. Staudigel (2003), Composition of altered oceanic crust at ODP Sites 801 and 1149, Geochem. Geophys. Geosyst., 4(6), 8910, doi:10.1029/ 2002GC000435.

Kempenaers, L., K. Janssens, K. P. Jochum, L. Vincze, B. Vekemans, A. Somogyi, M. Drakopoulos, and F. Adams (2003), Micro-heterogeneity study of trace elements in USGS, MPI-DING and NIST glass reference materials by means of synchrotron micro-XRF, J. Anal. At. Spectrom., $18,350-357$.

King, B. (1997), Traceability of chemical analysis, Analyst, 122, 197-204.

Kita, N. T., Y. Ikeda, S. Togashi, Y. Liu, Y. Morishita, and M. Weisberg (2004), Origin of ureilites inferred from a
SIMS oxygen isotopic and trace element study of clasts in the Dar al Gani 319 polymict ureilite, Geochim. Cosmochim. Acta, 20, 4213-4235.

Klein, M., F. Jesse, H. U. Kasper, and A. Gölden (2004), Chemical characterization of ancient pottery from Sudan by X-ray fluorescence spectrometry (XRF), electron microprobe analyses (EMPA) and inductively coupled plasma mass spectrometry (ICP-MS), Archaeometry, 46, 339-356.

Koga, K., E. Hauri, M. Hirschmann, and D. Bell (2003), Hydrogen concentration analyses using SIMS and FTIR: Comparison and calibration for nominally anhydrous minerals, Geochem. Geophys. Geosyst., 4(2), 1019, doi:10.1029/ 2002GC000378.

Kyser, T. K. (1986), Stable isotope variations in the mantle, in Stable Isotopes in High Temperature Geological Processes, Rev. Mineral., vol. 16, edited by J. W. Valley, H. P. Taylor Jr., and J. R. O'Neil, pp. 141-164, Mineral. Soc. of Am., Washington, D. C.

Latkoczy, C., and D. Günther (2002), Enhanced sensitivity in inductively coupled plasma sector field mass spectrometry for direct analysis using laser ablation (LA-ICP-SFMS), J. Anal. At. Spectrom., 17, 1264-1270.

Le Roux, P. J., S. B. Shirey, L. Benton, E. H. Hauri, and T. D. Mock (2004), In situ, multiple-multiplier, laser ablation ICPMS measurement of boron isotopic composition $\left(\delta^{11} \mathrm{~B}\right)$ at the nanogram level, Chem. Geol., 203, 123-138.

Liu, X., and H. S.C, O'Neill (2004), Partial melting of spinel lherzolite in the system $\mathrm{CaO}-\mathrm{MgO}-\mathrm{Al}_{2} \mathrm{O}_{3}-\mathrm{SiO}_{2} \pm \mathrm{K}_{2} \mathrm{O}$ at 1.1 Gpa, J. Petrol., 45, 1339-1368.

Longerich, H. P., S. E. Jackson, and D. Günther (1996), Laser ablation inductively coupled plasma mass spectrometric transient signal data acquisition and analyte concentration calculation, J. Anal. At. Spectrom., 11, 899-904.

Ludwig, K. R. (1993), PBDAT (version 1.24), A computer program for processing $\mathrm{Pb}-\mathrm{U}-\mathrm{Th}$ isotope data, U.S. Geol. Surv. Open File Rep., 88-542.

Ludwig, K. R. (1994), Analyst (version 2.20), A computer program for control of a thermal-ionization, single-collector mass-spectrometer, U.S. Geol. Surv. Open File Rep., 92-543.

Marschall, H. R., and T. Ludwig (2004), The low-boron contest: Minimising surface contamination and analysing boron concentrations at the $\mathrm{ng} / \mathrm{g}$-level by secondary ion mass spectrometry, Mineral. Petrol., 81, 265-278.

Mattey, D., D. Lowry, and C. Macpherson (1994), Oxygen isotope composition of mantle peridotite, Earth Planet. Sci. Lett., 128, 231-241.

Mostefaoui, S., N. T. Kita, S. Togashi, S. Tachibana, H. Nagahara, and Y. Morishita (2002), The relative formation ages of ferromagnesian chondrules inferred from their initial aluminum-26/aluminum-27 ratios, Meteorit. Planet. Sci., 37, 421-438.

Muehlenbachs, K. (1986), Alteration of the oceanic rust and the ${ }^{18} \mathrm{O}$ history of seawater, in Stable Isotopes in High Temperature Geological Processes, Rev. Mineral., vol. 16, edited by J. W. Valley, H. P. Taylor Jr., and J. R. O’Neil, pp. $452-$ 444, Mineral. Soc. of Am., Washington, D. C.

Münker, C., S. Weyer, E. Scherer, and K. Mezger (2001), Separation of high field strength elements $(\mathrm{Nb}, \mathrm{Ta}, \mathrm{Zr}, \mathrm{Hf})$ and $\mathrm{Lu}$ from rock samples for MC-ICPMS measurements, Geochem. Geophys. Geosyst., 2(12), doi:10.1029/ 2001GC000183.

Nash, W. P. (1992), Analysis of oxygen with the electron microprobe: Applications to hydrated glass and minerals, Am. Mineral., 77, 453-457.

Newsom, H. E., W. M. White, K. P. Jochum, and A. W. Hofmann (1986), Siderophile and chalcophile element abun- 
dances in oceanic basalts, $\mathrm{Pb}$ isotope evolution and growth of the Earth's core, Earth Planet. Sci. Lett., 80, 299-313.

Ottolini, L., P. Bottazzi, and R. Vannucci (1993), Quantification of lithium, beryllium, and boron in silicates by secondary ion mass spectrometry using conventional energy filtering, Anal. Chem., 65, 1961-1968.

Paule, R. C., and J. Mandel (1982), Consensus values and weighting factors, J. Res. Natl. Bur. Stand., 87, 377-385.

Pearce, N. J. G., W. T. Perkins, J. A. Westgate, M. P. Gorton, S. E. Jackson, C. R. Neal, and S. P. Chenery (1997), A compilation of new and published major and trace element data for NIST SRM 610 and NIST SRM 612 glass reference materials, Geostand. Newsl., 21, 115-144.

Potts, P. J. (1997), A glossary of terms and definitions used in analytical chemistry, Geostand. Newsl., 21, 157-161.

Pouchou, J.-L., and F. Pichoir (1991), Quantitative analysis of homogeneous or stratified microvolumes applying the model "PAP", in Electron Probe Quantitation, edited by K. F. J. Heinrich and D. E. Newbury, pp. 31-75, Springer, New York.

Raczek, I., K. P. Jochum, and A. W. Hofmann (2003), Neodymium and strontium isotope data for USGS reference materials BCR-1, BCR-2, BHVO-1, BHVO-2, AGV-1, AGV-2, GSP-1, GSP-2 and eight MPI-DING reference glasses, Geostand. Newsl., 27, 173-179.

Rankenburg, K., J. C. Lassiter, and G. Brey (2004), Origin of megacrysts in volcanic rocks of the Cameroon volcanic chain-constraints on magma genesis and crustal contamination, Contrib. Mineral. Petrol., 147, 129-144.

Rocholl, A. B. E., et al. (1997), Chemical characterisation of NIST silicate glass reference material SRM 610 by ICP-MS, TIMS, LIMS, SSMS, INAA, AAS and PIXE, Geostand. Newsl., 21, 101-114.

Rodushkin, I., M. D. Axelsson, S. Malinovsky, and D. C. Baxter (2002), Analyte- and matrix-dependent elemental response in laser ablation inductively coupled mass spectrometry. Part 2. Implications for multi-element analyses, J. Anal. At. Spectrom., 17, 1231-1239.

Rosman, K. J. R., and P. D. P. Taylor (1998), Isotopic compositions of the elements 1997, Pure Appl. Chem., 70, 217-236.

Rosner, M., and A. Meixner (2004), Boron isotopic composition and concentration of ten geological reference materials, Geostand. Geoanal. Res., 28, 431-441.

Rumble, D., III, and T. C. Hoering (1994), Analysis of oxygen and sulfur isotope ratios in oxide and sulfide minerals by spot heating with a carbon dioxide laser in a fluorine atmosphere, Accounts Chem. Res., 27, 237-241.

Smit, Z., K. Janssens, O. Schalm, and M. Kos (2004), Spread of facon-de-Venise glassmaking through central and western Europe, Nucl. Instrum. Methods Phys. Res., Ser. B, 213, 717-722.

Stoll, B., K. P. Jochum, and M. Willbold (2003), MPI-DING geological reference glasses: A comparison of LA-ICPMS with isotope dilution data, in Massenspektrometrische Verfahren der Elementspurenanalyse, abstract volume, p. 63, EUROLAB-Deutschland, Berlin.

Straub, S. M., G. D. Layne, A. Schmidt, and C. H. Langmuir (2004), Volcanic glasses at the Izu arc volcanic front: New perspectives on fluid and sediment melt recycling in subduction zones, Geochem. Geophys. Geosyst., 5, Q01007, doi:10.1029/2002GC000408

Sun, W. D., V. C. Bennett, S. M. Eggins, R. J. Arculus, and M. Perfit (2003), Rhenium systematics in submarine MORB and Back-arc basin glasses: Laser ablation ICP-MS results, Chem. Geol., 196(1-4), 259-281.

Sun, W. D., R. J. Arculus, V. S. Kamenetsky, and R. A. Binns (2004), Release of gold-bearing fluids in convergent margin magmas prompted by magnetite crystallization, Nature, 431, 975-978

Sylvester, P. J., and S. M. Eggins (1997), Analysis of Re, Au, $\mathrm{Pd}, \mathrm{Pt}$ and $\mathrm{Rh}$ in NIST glass certified reference materials and natural basalt glasses by laser ablation ICP-MS, Geostand. Newsl., 21, 215-229.

Taylor, B. E. (1986), Magmatic volatiles: Isotopic variation of $\mathrm{C}, \mathrm{H}$, and $\mathrm{S}$, in Stable Isotopes in High Temperature Geological Processes, Rev. Mineral., vol. 16, edited by J. W. Valley, H. P. Taylor, Jr., and J. R. O'Neil, pp. 185-226, Mineral. Soc. of Am., Washington, D. C.

Taylor, H. P., Jr., and S. M. F. Sheppard (1986), Igneous rocks: I. Processes of isotopic fractionation and isotope systematics, in Stable Isotopes in High Temperature Geological Processes, Rev. Mineral., vol. 16, edited by J. W. Valley, H. P. Taylor Jr., and J. R. O’Neil, pp. 227-272, Mineral. Soc. of Am., Washington, D. C.

Tiepolo, M., A. Zanetti, and R. Vannucci (2005a), Determination of $\mathrm{Li}, \mathrm{Be}$ and $\mathrm{B}$ at trace level with laser ablation-inductively coupled plasma-sector field mass spectrometry, Geostand. Geoanal. Res., 29, 211-224.

Tiepolo, M., C. Bouman, R. Vannucci, and J. B. Schwieters (2005b), Laser ablation multicollector ICPMS of $\delta^{11} \mathrm{~B}$ in geological samples, Appl. Geochem., in press.

Uriano, G. A., and C. C. Gravatt (1977), The role of reference materials and reference methods in chemical analysis, $C R C$ Crit. Rev. Anal. Chem., 6, 361-411.

Valley, J. W., N. Kitchen, M. J. Kohn, C. R. Niendorf, and M. J. Spicuzza (1995), UWG-2, a garnet standard for oxygen isotope ratios: Strategies for high precision and accuracy with laser heating, Geochim. Cosmochim. Acta, 59, 5223-5231.

Vennemann, T. W., and J. R. O'Neil (1993), A simple and inexpensive method of hydrogen isotope and water analyses of minerals and rocks based on zinc reagent, Chem. Geol., $103,227-234$

Villaseca, C., C. Martín Romera, J. De la Rosa, and L. Barbero (2003), Residence and redistribution of REE, Y, Zr, Th and $\mathrm{U}$ during granulite-facies metamorphism: Behaviour of accessory and major phases in peraluminous granulites of central Spain, Chem. Geol., 200, 293-323.

Weyer, S., C. Münker, M. Rehkämper, and K. Mezger (2002), Determination of ultra-low $\mathrm{Nb}, \mathrm{Ta}, \mathrm{Zr}$ and $\mathrm{Hf}$ concentrations and the chondritic $\mathrm{Zr} / \mathrm{Hf}$ and $\mathrm{Nb} / \mathrm{Ta}$ ratios by isotope dilution analyses with multiple collector ICP-MS, Chem. Geol., 187, 295-313.

Willbold, M., and K. P. Jochum (2005), Multi-element isotope dilution sector field ICPMS: A precise technique for the analysis of geological materials and its application to geological reference materials, Geostand. Geoanal. Res., 29, 6382 .

Willbold, M., K. P. Jochum, I. Raczek, M. A. Amini, B. Stoll, and A. W. Hofmann (2003), Validation of multi-element isotope dilution ICPMS for the analysis of basalts, Anal. Bioanal. Chem., 377, 117-125.

Woodhead, J. D. (2002), A simple method for obtaining highly accurate $\mathrm{Pb}$-isotope data by MC-ICPMS, J. Anal. At. Spectrom., 17, 1381-1385. 